\title{
Pemodelan Proses Bisnis Organisasi Pondok Pesantren Berdasarkan Standar Sekolah Berasrama Menggunakan Work Breakdown Structure (WBS)
}

\author{
Miftach Noorvickia Mu'afaq ${ }^{1, *}$, Septian Yustina Yasin², Abunawas Arifandi ${ }^{3}$, Muhammad Ainul \\ Yaqin $^{4}$ \\ Jurusan Teknik Informatika, Universitas Islam Negeri Maulana Malik Ibrahim, Indonesia \\ ${ }^{1} 17650096 @$ student.uin-malang.ac.id; ${ }^{2} 17650031 @$ student.uin-malang.ac.id; ${ }^{3} 17650020 @$ student.uin-malang.ac.id; \\ ${ }^{4}$ yaqinov@ti.uin-malang.ac.id; \\ * corresponding author
}

INFO ARTIKEL

\section{Sejarah Artikel}

Diterima: 12 Desember 2019

Direvisi: 22 Mei 2020

Diterbitkan: 30 Desember 2020

Kata Kunci

Pemodelan Proses Bisinis Standar Sekolah Berasrama Work Breakdown Structure

\section{ABSTRAK}

Pondok Pesantren menjadi salah satu lembaga pendidikan yang berbasis islami dengan berakar dari budaya masyarakat yang ada di Indonesia. Pada pondok pesantren, dalam melakukan suatu kegiatan yang ada di dalamnya pasti mempunyai proses bisnis yang harus dijalankan. Sebuah pondok pesantren diharapkan memiliki proses bisnis yang baik dengan memenuhi standar sekolah berasrama (SSA) yang tertuang dalam national minimum standards for boarding schools oleh welsh assembly government. WBS dianggap sebagai metode yang dapat membantu dalam pembuatan proses bisnis.Tujuan dari penelitian ini adalah untuk menghasilkan sebuah breakdown struktur aktivitas pondok pesantren berdasarkan dengan standar minimum nasional sekolah berasrama. Dengan data yang digunakan merupakan data sekunder yang didapatkan dari studi literatur sekolah standar asrama (SSA). Pembuatan proses bisnis Sekolah Standar Asrama dapat dilakukan dengan menerapkan Work Breakdown Structure. Penelitian ini menghasilkan proses bisnis dari 52 standar Sekolah Standar Asrama yang nantinya dapat diterapkan di sekolah berasrama secara umum dan pondok pesantren secara khusus.

\section{PENDAHULUAN}

Pondok Pesantren menjadi salah satu lembaga pendidikan yang berbasis islami dengan berakar dari budaya masyarakat yang ada di Indonesia [1]. Untuk menjadi pondok pesantren yang berkualitas maka harus mempunyai proses bisnis berdasarkan dengan standar yang mendukung hal tersebut. Selain itu, dalam melakukan suatu kegiatan yang ada di dalam pondok pesantren pasti mempunyai proses bisnis yang harus dijalankan [2]. Model proses bisnis adalah serangkaian kegiatan yang berhasil dikoordinasikan dalam suatu organisasi dan lingkungan teknis [3]. Proses bisnis organisasi dalam sebuah pondok pesantren sangat diperlukan dan harus dimanajemen dengan baik, dikarenakan hal ini adalah unsur yang terpenting dari berlangsungnya sebuah pondok pesantren [2]. Dalam pemodelan proses bisnis yang peneliti gunakan dalam penelitian ini yakni mendetailkan titik aktivitas pada setiap standar dan menjelaskan tiap-tiap task ataupun kronologi dari setiap standar yang akan kami gunakan, sehingga menghasilkan kualitas pondok pesantren yang lebih baik. Berdasarkan hal tersebut, peneliti menggunakan Standar Sekolah Berasrama (SSA) untuk dijadikan acuan dalam melakukan setiap kegiatan dalam organisasi pondok pesantren.

Standar Sekolah Berasrama (SSA) merupakan standar dalam ketentuan berasrama atau pondok pesantren yang tertuang dalam national minimum standards for boarding schools oleh welsh assembly government., yang mana SSA terdiri dari 52 standar yang meliputi 5 
pokok bahasan. Adapun pokok bahasan tersebut adalah kebijakan dan prosedur kesejahteraan, organisasi dan manajemen, dukungan kesejahteraan pada santri, staffing dan premis [4]. Untuk detail 52 standarnya akan dibahas pada bab selanjutnya.

Manajemen dan kepemimpinan sangat penting dalam suatu lembaga pendidikan [5]. Kesiapan pesantren dalam mengatur setiap aktivitas harus lebih diperhatikan, sehingga menghasilkan kegiatan yang memenuhi standar SSA. Untuk dapat memenuhi hal tersebut, diperlukan adanya sebuah proses bisnis yang diperoleh dari analisis kegiatan menggunakan Work Breakdown Structure (WBS). WBS dianggap sebagai metode yang dapat membantu dalam pembuatan proses bisnis. WBS merupakan hierarki penurunan lingkup pekerjaan hingga menjadi level terkecil sehingga memudahkan proses pengelolaan dan pengendalian suatu proyek [2]. Selain itu WBS juga merupakan suatu cara yang tepat dalam mengidentifikasikan aktivitas ataupun kegiatan dalam suatu proyek yang dapat dikelompokkan menurut hirarki tertentu secara logika yang kemudian dapat dilimpahkan kepada orang-orang yang bersangkutan atau tenaga tertentu untuk melaksanakannya. WBS tidak hanya digunakan pada proyek yang memiliki lingkup besar saja namun dapat diaplikasikan pada proyek kecil yang mungkin mempunyai aktivitas atau kegiatan proyek yang komplek [6]. Penelitian terkait mengenai WBS yang pernah dilakukan oleh [7] yang menggunakan konsep BPMN, yang menghasilkan pemodelan sistem manajemen informasi dalam bentuk bisnis proses pada beberapa aktivitas diantaranya pengajuan dan juga penanganan, evaluasi usulan, penanganan usulan yang diterima, pencairan dana, monitoring, pelaporan dan seminar hasil. Selain itu, penelitian yang pernah dilakukan oleh [8] juga membahas mengenai penggunaan WBS, dalam penelitian tersebut tekniknya menggunakan sebuah WBS yang membagi teknologi menjadi komponen terpisah untuk tujuan memperkirakan biaya unit.

Berdasarkan hal tersebut, Pada penelitian ini peneliti mengusulkan pemodelan bisnis Pemodelan Proses Bisnis Organisasi Pondok Pesantren Berdasarkan Standar Sekolah Berasrama (SSA) menggunakan Work Breakdown Structure (WBS) dan diperoleh sebuah pernyataan masalah yakni bagaimana membuat proses bisnis Standar Sekolah Asrama (SSA) dengan menerapkan WBS yang nantinya penelitian ini diharapkan dapat menghasilkan pemodelan proses bisnis organisasi dalam pondok pesantren yang sesuai dengan standar yang telah ditentukan dan menjadi asrama pondok pesantren yang lebih baik, dan juga dapat memberikan wawasan mengenai penggunaan WBS dan standart-standart yang seharusnya ada dalam pondok pesantren berdasarkan SSA.

\section{METODE}

Metode penelitian yang diimplementasikan terbagi ke dalam beberapa tahapan:

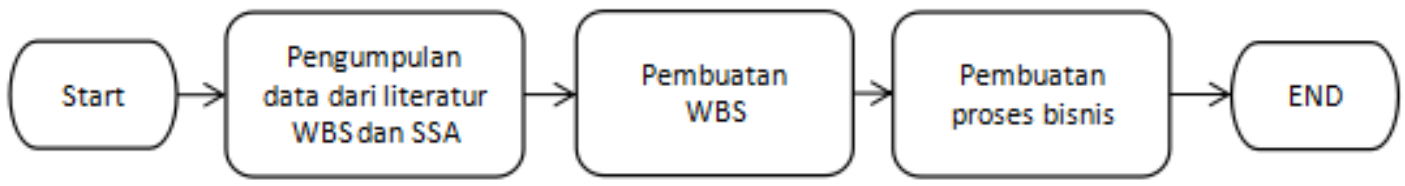

Gambar 1. Alur penelitian

Gambar 1 menjelaskan alur penelitian yang dilakukan, dimulai dari pengumpulan data dari literatur mengenai WBS dan SSA, kemudian pembuatan WBS, dan dilanjutkan dengan langkah yang terakhir adalah pembuatan proses bisnis berdasarkan WBS yang dibuat. adapun penjelasan tiap tahapannya sebagai berikut: 


\section{Pengumpulan data dari literatur WBS dan SSA}

Data yang digunakan merupakan data sekunder yang didapatkan dari studi literatur sekolah standar asrama (SSA) dan WBS. Terdapat 5 pokok bahasan umum pada standar ini yakni kebijakan dan prosedur kesejahteraan, organisasi dan manajemen, dukungan kesejahteraan kepada dewan, staffing, dan premis. yang terdiri dari 52 standar yang terdapat pada tabel 1. Poin-poin standar tersebut nantinya akan di-breakdown menggunakan WBS. SSA merupakan kumpulan dari standar sekolah berasrama yang ditetapkan oleh welsh assembly government. SSA dalam penelitian ini digunakan sebagai data sekunder yang mana terdiri dari lima pokok bahasan pada standart ini diantaranya adalah kebijakan dan prosedur kesejahteraan, organisasi dan manajemen, dukungan kesejahteraan kepada dewan, staffing, dan premis. Adapun rincian dari keseluruhan standar dapat kami presentasikan menjadi tabel berikut:

Tabel 1.Standar sekolah berasrama

\begin{tabular}{|c|c|c|}
\hline No & $\begin{array}{c}\text { Pokok } \\
\text { Bahasan }\end{array}$ & Standard ke- \\
\hline 1 & $\begin{array}{l}\text { Kebijakan Dan } \\
\text { Prosedur } \\
\text { Kesejahteraan }\end{array}$ & $\begin{array}{l}\text { Pernyataan prinsip dan praktik asrama } \\
\text { Melawan penindasan (asrama dilindungi dari intimidasi) } \\
\text { Perlindungan anak, tanggapan atas tuduhan } \\
\text { Perilaku, disiplin, hukuman, penghargaan dan pengekangan } \\
\text { Menanggapi keluhan (keluhan asrama ditanggapi dengan memadai) } \\
\text { Kesehatan asrama ditingkatkan } \\
\text { Catatan kesehatan penghuni asrama }\end{array}$ \\
\hline 2 & $\begin{array}{l}\text { Organisasi } \\
\text { Dan } \\
\text { Manajemen }\end{array}$ & $\begin{array}{l}\text { Ada kepemimpinan yang jelas dari pesantren } \\
\text { Manajemen Krisis } \\
\text { Organisasi pesantren berkontribusi pada kesejahteraan para pesantren } \\
\text { Kegiatan dan waktu luang } \\
\text { Mengamankan pandangan penghuni asrama } \\
\text { Prefek } \\
\text { Staf dan dukungan pihak luar pada santri }\end{array}$ \\
\hline 3 & $\begin{array}{l}\text { Dukungan } \\
\text { Kesejahteraan } \\
\text { Kepada Santri }\end{array}$ & $\begin{array}{l}\text { 15. } \\
\text { 16. }\end{array}$ Merawatan medis dan pertolongan pertama \\
\hline 4 & Staffing & $\begin{array}{l}\text { Santri diawasi secara memadai oleh staf } \\
\text { Pengawasan para penghuni asrama yang meninggalkan lokasi sekolah }\end{array}$ \\
\hline
\end{tabular}




\begin{tabular}{|c|c|c|}
\hline & & 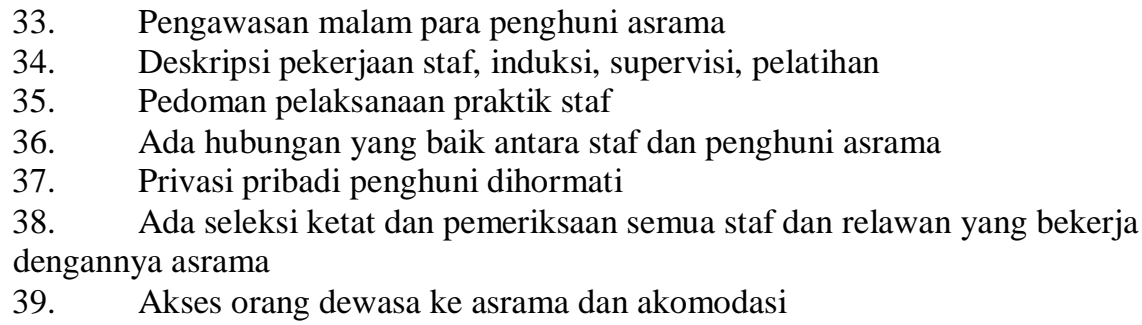 \\
\hline 5 & Premis & 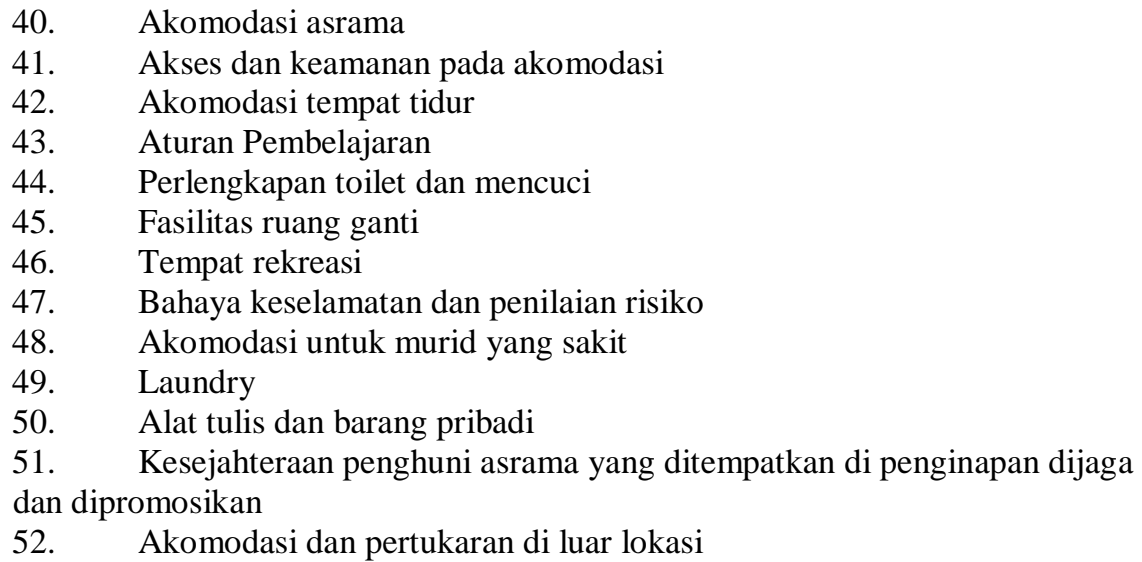 \\
\hline
\end{tabular}

Tabel 1 tersebut merupakan 52 standar sekolah berasrama yang ditetapkan oleh welsh assembly government, yang kemudian langkah selanjutnya adalah dilakukan Work Breakdown Structure berdasarkan tabel tersebut untuk menghasilkan proses bisnis.

\section{Work Breakdown Structure (WBS)}

Work Breakdown Structure (WBS) adalah suatu cara yang sangat tepat dalam mengidentifikasikan aktivitas atau kegiatan dalam suatu proyek yang dapat dikelompokkan menurut hirarki tertentu secara logika yang kemudian dapat dilimpahkan kepada orangorang atau tenaga tertentu untuk melaksanakannya, selain itu Work Breakdown Structure (WBS) hampir memiliki pengertian yang mirip dengan daftar tugas. WBS adalah sebuah cara yang digunakan untuk mendefinisikan dan mengelompokkan tugas-tugas dari sebuah proyek menjadi bagian-bagian kecil sehingga lebih mudah diatur [6]. Struktur rincian kerja (WBS) memecah proyek teknik menjadi sub proyek, tugas, sub tugas, paket kerja, dan sebagainya. WBS adalah alat perencanaan penting yang menghubungkan tujuan dengan sumber daya dan aktivitas dalam kerangka kerja yang logis. WBS menjadi pemantau status penting selama implementasi aktual karena penyelesaian sub tugas diukur terhadap rencana proyek. [9]. WBS dapat disebut sebagai blok bangunan dasar untuk memulai, merencanakan, melaksanakan, dan memantau serta mengendalikan proses yang digunakan untuk mengelola proyek [10]. Penggunaan WBS memudahkan dalam proses pengelolaan dan pengendalian proyek [11], selain itu tujuan dari penggunaan WBS agar komponen-komponen kegiatan atau aktivitas tetap berorientasi ke tujuan dari suatu proyek yang dikerjakan [12]. WBS juga memudahkan penjadwalan dan pengendalian karena merupakan elemen-elemen perencanaan yang terdiri dari kerangka-kerangka.

Work Breakdown Structure (WBS) terdiri dari 2 macam yakni wbs berbasis hasil dan wbs berbasis fase. Fokus pada penelitian ini adalah WBS berbasis hasil yang mana Struktur Perincian Kerja Berbasis Hasil Kerja memiliki hubungan antara hasil proyek yaitu, produk, layanan, atau hasil dan ruang lingkup yaitu, pekerjaan yang akan dilaksanakan. 


\section{Pembuatan Work Breakdown Structure (WBS)}

Setelah mempelajari berbagai literatur mengenai WBS dan menganalisis SSA. peneliti kemudian melanjutkan pada tahap pembuatan Work Breakdown Structure (WBS) dari SSA tersebut. WBS dalam penelitian ini adalah WBS hasil, sehingga dari setiap standar yang terdapat dalam SSA tersebut akan dijabarkan sampai pada titik aktivitas. adapun hasil WBS dari SSA terdapat pada tabel 2 berikut ini:

Tabel 2. Work Breakdown Structure berbasis hasil dari standar sekolah asrama

\begin{tabular}{|c|c|c|c|}
\hline No & $\begin{array}{c}\text { Pokok } \\
\text { Bahasan }\end{array}$ & Standard ke- & Aktivitas \\
\hline \multirow[t]{3}{*}{1} & \multirow[t]{3}{*}{$\begin{array}{l}\text { Kebijakan } \\
\text { Dan } \\
\text { Prosedur } \\
\text { Kesejahtera } \\
\text { an }\end{array}$} & $\begin{array}{l}\text { 1. Pernyataan } \\
\text { prinsip dan } \\
\text { praktik asrama }\end{array}$ & $\begin{array}{l}\text { Premis : } \\
\text { - Rapat tahunan perumusan visi misi dan tata tertib } \\
\text { pesantren } \\
\text { Direktur : } \\
\text { - } \quad \text { Memimpin jalannya rapat } \\
\text { - } \quad \text { Apa bila dalam rapat terdapat lebih dari satu pandangan } \\
\text { visi misi dan tata tertib, maka direktur menetapkan yang paling } \\
\text { sesuai dengan ajaran islam dan aktual } \\
\text { - Menetapkan visi misi dan tata tertib kehidupan Asrama } \\
\text { - Apa bila dalam rapat terdapat lebih dari satu pandangan } \\
\text { kebijakan mekanisme kerja, maka direktur menetapkan yang } \\
\text { paling sesuai dengan ajaran islam dan aktual } \\
\text { - Menetapkan kebijakan mekanisme kerja kehidupan } \\
\text { Asrama } \\
\text { Pengurus : } \\
\text { - Merumuskan visi misi dan tata tertib kehidupan Asrama } \\
\text { - Merumuskan kebijakan mekanisme kerja kehidupan } \\
\text { Asrama } \\
\text { - } \quad \text { Merumuskan melaksanakan mekanisme kerja } \\
\text { kehidupan Asrama }\end{array}$ \\
\hline & & $\begin{array}{l}\text { 2. Melawan } \\
\text { penindasan } \\
\text { (asrama } \\
\text { dilindungi dari } \\
\text { intimidasi) }\end{array}$ & $\begin{array}{l}\text { Premis: } \\
\text { - } \quad \text { Santri mendapat penindasan } \\
\text { Santri : } \\
\text { - } \quad \text { Melapor kepada pengurus yang berwenang } \\
\text { Pengurus: } \\
\text { - } \quad \text { Menerima laporan dari korban penindasan } \\
\text { - } \quad \text { Menindaklanjuti laporan } \\
\text { - } \quad \text { Terdapat bukti atau saksi } \\
\text { - } \\
\text { Saksi : } \\
\text { Menetapkan pelaku penindasan } \\
\text { Penindas : } \\
\text { - } \quad \text { Memberikan kesaksian } \\
\text { Mendapatkan sanksi }\end{array}$ \\
\hline & & $\begin{array}{l}\text { 3. Perlindungan } \\
\text { anak }\end{array}$ & $\begin{array}{l}\text { Premis: } \\
\text { - } \quad \text { Adanya pelecahan maupun penindasan terhadap anak } \\
\text { Santri : } \\
\text { - } \quad \text { Melapor yang mendapat pelecahan maupun penindasan } \\
\text { kepada pengurus } \\
\text { Pengurus: } \\
\text { - } \quad \text { Menerima laporan dari korban pelecehan } \\
\text { - } \\
\text { - } \\
\text { - } \\
\text { - } \\
\text { Tenjaga kerdapat bukti atau saksi } \\
\text { Menetapkan pelaku pelecahan maupun penindasan }\end{array}$ \\
\hline
\end{tabular}




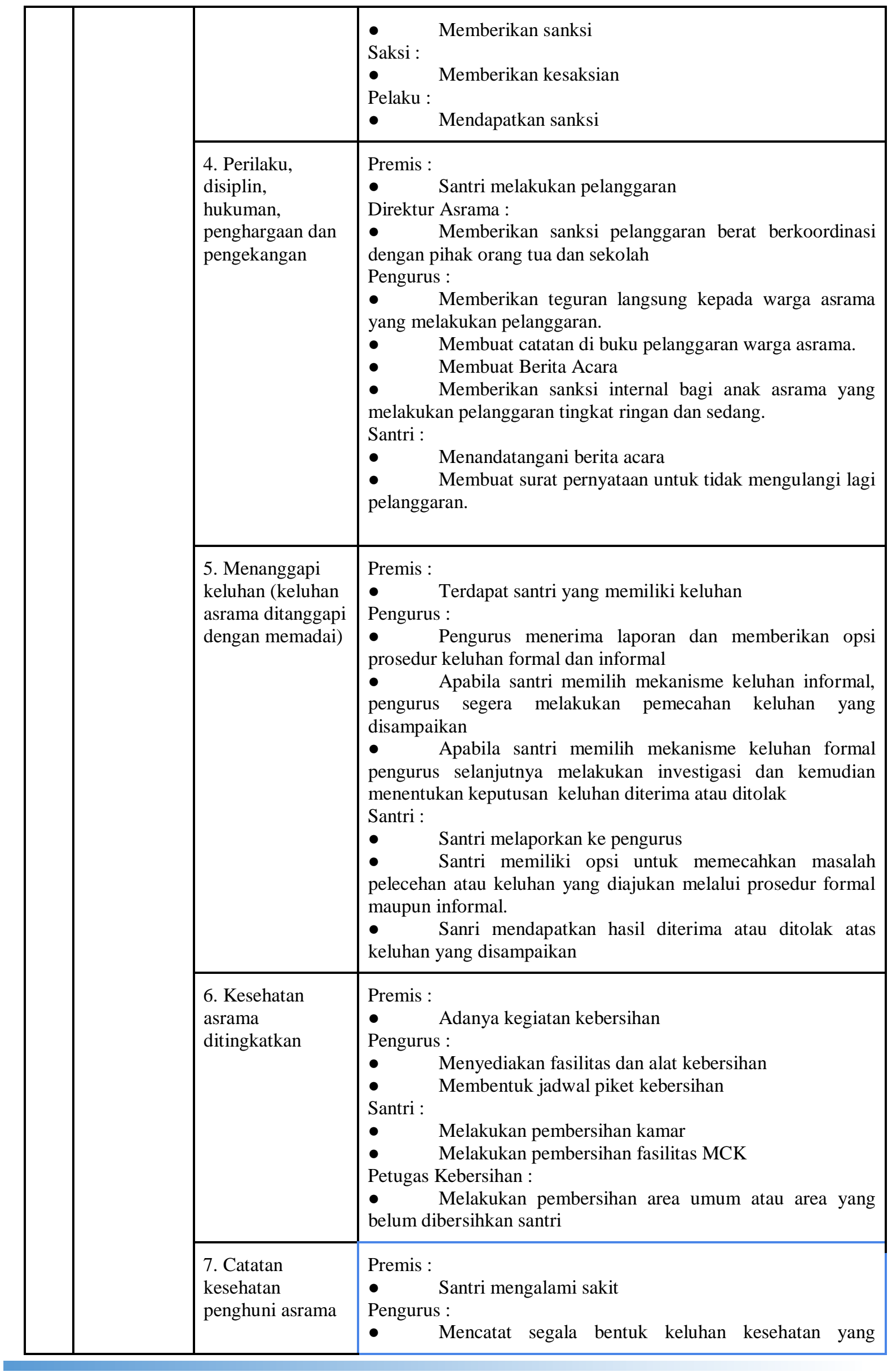




\begin{tabular}{|c|c|c|c|}
\hline & & & $\begin{array}{l}\text { dirasakan } \\
\text { - } \quad \text { Mencatat penanganan dan obat yang diberikan } \\
\text { - } \quad \text { Memberikan catatan kesehatan pada santri dan wal } \\
\text { santri } \\
\text { medis apabila melakukan rujukan } \\
\text { Santri : } \\
\text { - } \\
\quad \text { Mendapatkan catatan kesehatan }\end{array}$ \\
\hline \multirow{4}{*}{\multicolumn{2}{|c|}{$\begin{array}{l}\text { Organisasi } \\
\text { Dan } \\
\text { Manajemen }\end{array}$}} & $\begin{array}{l}\text { 8. Ada } \\
\text { kepemimpinan } \\
\text { yang jelas dari } \\
\text { pesantren }\end{array}$ & $\begin{array}{l}\text { Premis : } \\
\bullet \quad \text { Pemilihan ketua pondok pesantren } \\
\text { Ketua Pesantren : } \\
\text { - } \quad \text { Terpilih menjadi ketua } \\
\text { Ketua Yayasan : } \\
\text { - Menetapkan ketua pesantren } \\
\text { Anggota dewan Yayasan: } \\
\text { - } \quad \text { Mengusulkan nama Calon ketua baru } \\
\text { - Melakukan voting } \\
\text { Pengurus periode sebelumnya: } \\
\text { - } \quad \text { Mempersiapkan pemilihan umum }\end{array}$ \\
\hline & & $\begin{array}{l}\text { 9.Manajemen } \\
\text { Krisis }\end{array}$ & $\begin{array}{ll}\text { Premis : } \\
\bullet & \text { Kelengkapan fasilitas penunjang / mitigasi bencana } \\
\text { Pengurus : } \\
\bullet \quad \text { Menyiapkan fasilitas mitigasi bencana } \\
\bullet & \text { Mengadakan sosialisasi mengenai mitigasi bencana } \\
\bullet & \text { Menerima laporan kerusakan } \\
\bullet & \text { Merehabilitasi fasilitas yang rusak } \\
\text { Santri: } & \\
\bullet & \text { Mendapatkan sosialisasi penggunaan fasilitas mitigasi } \\
\text { bencana } & \\
\bullet & \text { Melakukan simulasi penanganan mitigasi bencana } \\
\bullet & \text { Menjaga fasilitas mitigasi bencana } \\
\bullet & \text { Melaporkan kerusakan fasilitas }\end{array}$ \\
\hline & & $\begin{array}{l}\text { 10.Organisasi } \\
\text { pesantren } \\
\text { berkontribusi } \\
\text { pada } \\
\text { kesejahteraan } \\
\text { para santri }\end{array}$ & $\begin{array}{l}\text { Premis : } \\
\text { Pengurus : } \\
\text { Pembagian kelompok belajar dan kamar } \\
\text { kemampuan, gender dan rekam jejak pendidikan sebelumnya } \\
\text { - Membagi kamar santri berdasarkan umur, gender dan } \\
\text { rekam jejak pendidikan } \\
\text { Santri: } \\
\text { - } \quad \text { Mendapatkan kelompok belajar yang sesuai } \\
\text { Mendapat pembagian kelompok kamar yang sesuai }\end{array}$ \\
\hline & & $\begin{array}{l}\text { 11.Kegiatan dan } \\
\text { waktu luang }\end{array}$ & $\begin{array}{l}\text { Premis : } \\
\bullet \quad \text { Ada waktu luang di luar agenda akademik } \\
\text { Pengurus : } \\
-\quad \text { Menyediakan kegiatan ekstrakurikuler } \\
-\quad \text { Melakukan pengawasan santri ketika kegiatan } \\
\text { ekstrakurikuler } \\
\text { Santri: } \\
-\quad \text { Berhak memilih mengikuti kegiatan tersebut atau tidak } \\
\text { ekstrakurikuler, santri wajib menaati peraturan kegiatan }\end{array}$ \\
\hline
\end{tabular}




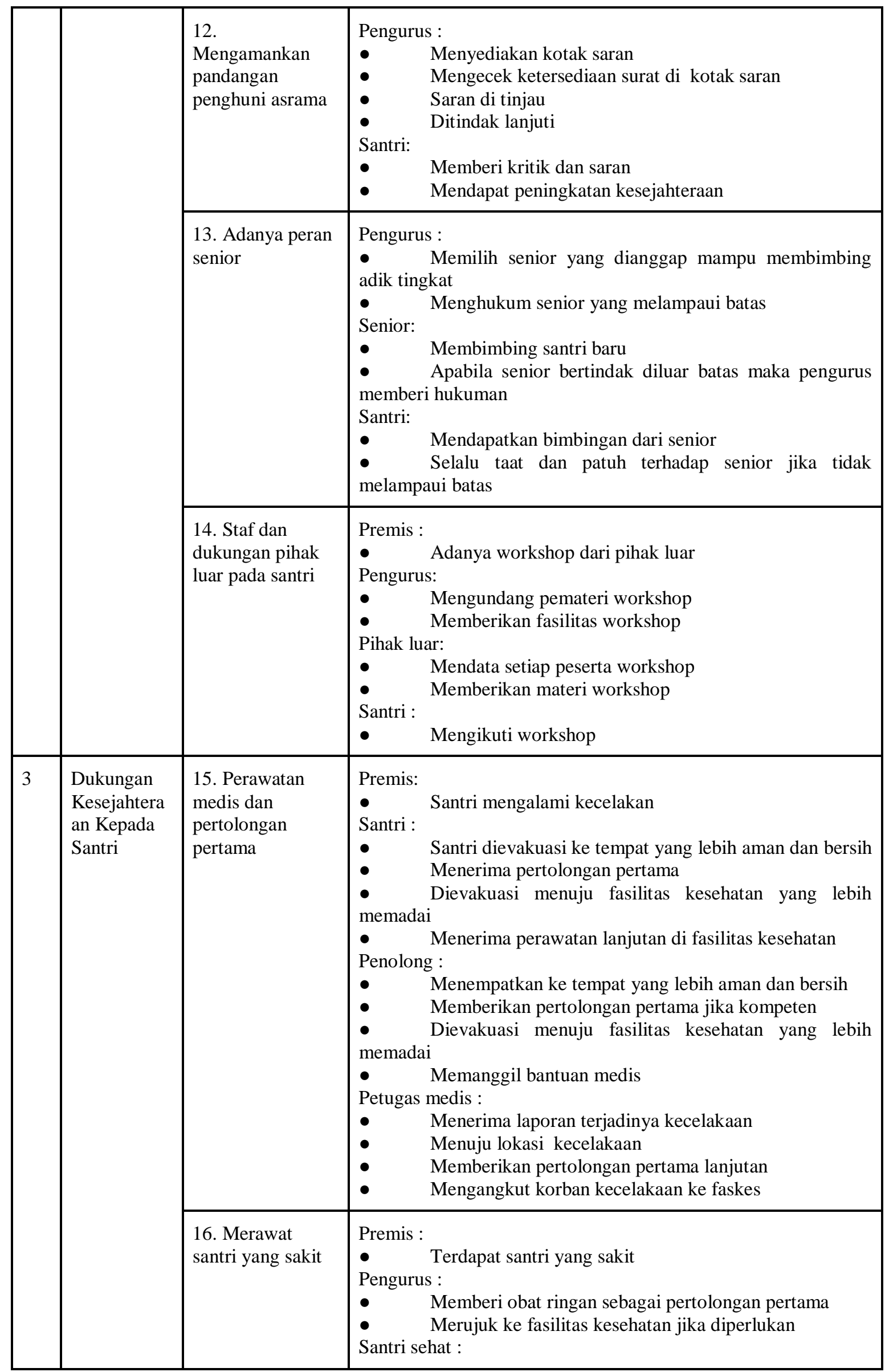




\begin{tabular}{|c|c|}
\hline & $\begin{array}{l}\text { - } \quad \text { Melaporkan status kesehatan satri sakit ke pengurus } \\
\text { - } \quad \text { Melayani kebutuhan makan dan minum santri sakit } \\
\text { Santri sakit : } \\
\text { - } \quad \text { Mendapatkan perawatan }\end{array}$ \\
\hline $\begin{array}{l}\text { 17. Manajemen } \\
\text { Kesehatan dan } \\
\text { masalah pribadi }\end{array}$ & $\begin{array}{l}\text { Pengurus : } \\
\bullet \quad \text { Menyediakan obat-obat umum } \\
\text { Santri : } \\
\text { - } \quad \text { Membawa obat pribadi dari luar } \\
\text { lain maka dititipkan ke pengurus }\end{array}$ \\
\hline $\begin{array}{l}\text { 18. Diskriminasi } \\
\text { dan persamaan } \\
\text { kesempatan }\end{array}$ & 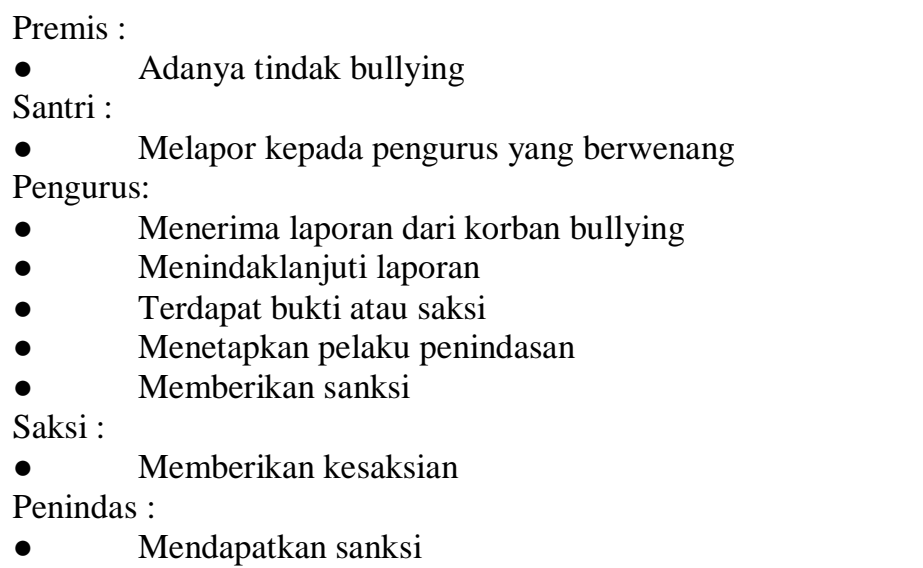 \\
\hline $\begin{array}{l}\text { 19. Penghuni } \\
\text { asrama dapat } \\
\text { menjaga kontak } \\
\text { pribadi dengan } \\
\text { orang tua dan } \\
\text { keluarga mereka }\end{array}$ & $\begin{array}{ll}\text { Premis : } \\
\bullet & \text { Kunjungan Orang tua } \\
\text { Pengurus : } \\
\text { - } & \text { Mencatat tamu/ orang tua yang menjenguk } \\
\bullet & \text { Menghubungi santri yang dijenguk } \\
\text { Orang Tua : } \\
- & \text { Melapor ke Pengurus } \\
\bullet & \text { Mengisi buku tamu } \\
\bullet & \text { Menuju ke ruang tamu/ ruang kunjungan } \\
\text { Santri : } & \\
\bullet & \text { Informasi kunjungan } \\
- & \text { Menuju ke ruang tamu }\end{array}$ \\
\hline $\begin{array}{l}\text { 20. Harta dan } \\
\text { uang penghuni } \\
\text { asrama dilindungi }\end{array}$ & $\begin{array}{l}\text { Pengurus : } \\
\text { - } \quad \text { Menyediakan fasilitas loker } \\
\text { berharga } \\
\text { Santri : } \\
\text { - } \\
\text { - } \\
\text { - } \\
\text { Menyimpan dibutuhkan pengurus menerima penitipan barang } \\
\text { Menitipkan barang berharga ke pengurus }\end{array}$ \\
\hline $\begin{array}{l}\text { 21. Pengenalan } \\
\text { Santri Baru }\end{array}$ & $\begin{array}{l}\text { Premis: } \\
\text { - Masa orientasi siswa } \\
\text { Pengurus: } \\
\text { - } \quad \text { Membentuk panitia dan pendamping } \\
\text { Santri baru: } \\
\text { - Mengatur pembagian pendamping } \\
\text { Pendamping : } \\
\text { - Mendampingi Santri baru } \\
\text { pesantren }\end{array}$ \\
\hline
\end{tabular}




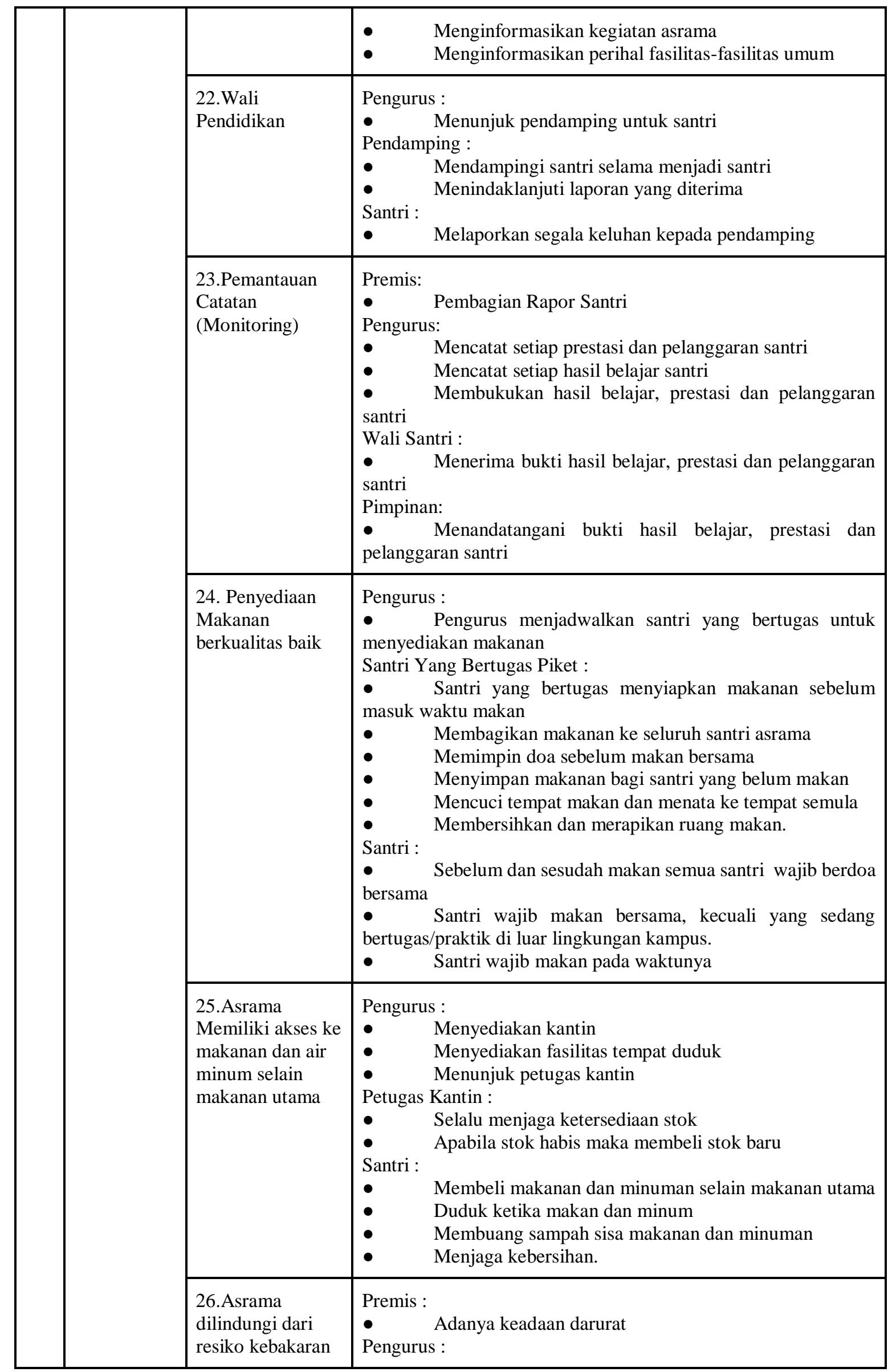




\begin{tabular}{|c|c|}
\hline & $\begin{array}{l}\text { Menyalakan alarm kebakaran } \\
\text { - } \quad \text { Apabila api kecil dan dapat dipadamkan maka } \\
\text { dipadamkan dengan alat yang tersedia } \\
\text { - } \quad \text { Apabila tidak maka memanggil petugas pemadam } \\
\text { kebakaran } \\
\text { - } \quad \text { Apabila ada korban menangani sesuai prosedur P3K } \\
\text { - } \quad \text { Mencatat korban terluka } \\
\text { - } \quad \text { Menyalakan alarm saat kondisi aman } \\
\text { - } \quad \text { Bertanggung jawab terhadap ketertiban saat evakuasi } \\
\text { Seluruh Warga Pesantren: } \\
\text { - } \quad \text { Menghentikan seluruh pekerjaan } \\
\text { - } \quad \text { Mengevakuasi diri dan menyelamatkan barang berharga } \\
\text { - } \quad \text { Berjalan dengan tenang ke pintu keluar dan menuju ke } \\
\text { titik kumpul } \\
\text { - } \quad \text { Apabila ada korban mendapatkan penanganan sesuai } \\
\text { prosedur P3K } \\
\text { - Apabila dampak kebakaran masih memungkinkan untuk } \\
\text { santri menetap maka santri kembali ke kamar ketika kondusif } \\
\text { - Apabila tidak maka santri dipulangkan } \\
\text { Petugas Pemadam Kebakaran: } \\
\text { - } \quad \text { Memadamkan kebakaran sesuai SOP pemadam } \\
\text { kebakaran }\end{array}$ \\
\hline $\begin{array}{l}\text { 27. Tuntutan yang } \\
\text { membebani Santri }\end{array}$ & $\begin{array}{l}\text { Premis : } \\
\bullet \quad \text { Terdapat tugas yang mebebani santri } \\
\text { Pengurus : } \\
\bullet \quad \text { Pengurus menerima laporan dan menindaklanjuti } \\
\text { laporan } \\
\bullet \quad \text { Laporan diterima dan melakukan penyesuaian tugas } \\
\text { Santri: } \\
\text { tugasnya } \\
\bullet \quad \text { Santri melaporkan keluhan ke pengurus perihal beban } \\
\text { Santri menerima tugas yang telah disesuaikan }\end{array}$ \\
\hline $\begin{array}{l}\text { 28.Akomodasi } \\
\text { anak selain siswa }\end{array}$ & $\begin{array}{l}\text { Pengurus : } \\
\text { - } \quad \text { Menyediakan fasilitas tempat tidur untuk anak selain } \\
\text { siswa } \\
\text { - } \quad \text { Menerima laporan kerusakan fasilitas tempat tidur anak } \\
\text { selain siswa. } \\
\text { - } \quad \text { Menindaklanjuti laporan } \\
\text { - } \quad \text { Melakukan tindakan rehabilitasi fasilitas tempat tidur } \\
\text { anak selain siswa } \\
\text { Anak selain siswa: } \\
\text { - } \quad \text { Menjaga kebersihan tempat tidur } \\
\text { - } \\
\text { - } \\
\text { tertulis }\end{array}$ \\
\hline $\begin{array}{l}\text { 29. Keselamatan } \\
\text { dan kesejahteraan } \\
\text { penghuni } \\
\text { dilindungi selama } \\
\text { aktivitas berisiko } \\
\text { tinggi. }\end{array}$ & $\begin{array}{l}\text { Pengurus : } \\
\text { - } \quad \text { Menyediakan fasilitas alat pelindung diri } \\
\text { Siswa : } \\
\text { - Menginventarisir alat pelindung diri } \\
\text { resiko tinggi } \\
\text { - Menggunakan alat pelindung diri ketika berkegiatan } \\
\text { digunakan }\end{array}$ \\
\hline $\begin{array}{l}\text { 30.Santri } \\
\text { memiliki akses ke } \\
\text { informasi }\end{array}$ & $\begin{array}{l}\text { Pengurus : } \\
\text { - } \quad \text { Menyediakan fasilitas papan informasi } \\
\text { - } \\
\text { Menyetempel informasi yang akan ditempel }\end{array}$ \\
\hline
\end{tabular}




\begin{tabular}{|c|c|c|c|}
\hline & & & $\begin{array}{l}\text { - Menempel informasi pada papan } \\
\text { Santri : } \\
\text { - Meminta izin memasang informasi pada papan } \\
\text { pengumuman } \\
\text { informasi }\end{array}$ \\
\hline \multirow[t]{5}{*}{4} & \multirow[t]{5}{*}{ Staffing } & $\begin{array}{l}\text { 31.Santri diawasi } \\
\text { secara memadai } \\
\text { oleh staf }\end{array}$ & $\begin{array}{l}\text { Pengurus : } \\
\text { - Menunjuk pendamping untuk kelompok santri } \\
\text { Pendamping: } \\
\text { - } \quad \text { Memperoleh wewenang menjadi pendamping } \\
\text { - } \quad \text { Mendapat fasilitas kamar dekat dengan santri } \\
\text { dampingan } \\
\text { berasrama } \\
\text { - } \quad \text { Menjembatani kebutuhan santri dampingan } \\
\text { - } \quad \text { Mengawasi santri dampingan } \\
\text { - } \\
\text { Santri : } \\
\text { - } \\
\text { - Santri memperoleh pendamping } \\
\text { kepada pendamping } \\
\text { - } \quad \text { Mengikuti kegiatan diskusi bersama dampingan }\end{array}$ \\
\hline & & $\begin{array}{l}\text { 32.Pengawasan } \\
\text { para penghuni } \\
\text { asrama yang } \\
\text { meninggalkan } \\
\text { lokasi sekolah }\end{array}$ & $\begin{array}{l}\text { Premis : } \\
\text { - Santri akan meninggalkan asrama dan untuk menginap } \\
\text { di luar pondok } \\
\text { Santri : } \\
\text { meninggal kan } \\
\text { - Membawa surat keterangan apabila meninggalkan } \\
\text { pesantren karena sakit } \\
\text { Pengurus : } \\
\text { - Memberikan izin kepada santri maksimal } 5 \text { hari }\end{array}$ \\
\hline & & $\begin{array}{l}\text { 33.Pengawasan } \\
\text { malam para } \\
\text { penghuni asrama }\end{array}$ & $\begin{array}{l}\text { Pengurus : } \\
\text { - } \quad \text { Membuat peraturan jam malam } \\
\text { Santri yang piket : } \\
\text { keamanan } \\
\text { Selaksanakan piket ronda malam bersama tim } \\
\text { Santri yang tidak piket : } \\
\text { - } \quad \text { Santri menaati peraturan jam malam } \\
\quad \text { Mendapat sanksi jika melanggar }\end{array}$ \\
\hline & & $\begin{array}{l}\text { 34.Deskripsi } \\
\text { pekerjaan staf, } \\
\text { induksi, supervisi, } \\
\text { pelatihan }\end{array}$ & $\begin{array}{l}\text { Pimpinan staff : } \\
\text { - } \quad \text { Mengadakan sosialisasi pada anggota divisinya } \\
\text { - } \quad \text { Mempersiapkan pelatihan kepada para anggotanya } \\
\text { - } \quad \text { Mengganti pelatihan yang sudah dilakukan dengan } \\
\text { pelatihan baru } \\
\text { - } \quad \text { Mendapatkan para anggota staf dengan skill baru } \\
\text { Anggota staff : } \\
\text { - } \quad \text { Mengikuti pelatihan } \\
\text { - Mendapat fasilitas pelatihan dan skill baru dari para } \\
\text { pimpinan pengurus }\end{array}$ \\
\hline & & $\begin{array}{l}\text { 35. Pedoman } \\
\text { pelaksanaan } \\
\text { praktik staf }\end{array}$ & $\begin{array}{l}\text { Ketua divisi: } \\
\bullet \quad \text { Membuat jobdesc untuk divisinya } \\
\bullet \quad \text { Mengontrol kinerja anggota nya }\end{array}$ \\
\hline
\end{tabular}




\begin{tabular}{|c|c|c|c|}
\hline & & & $\begin{array}{l}\text { - } \quad \text { Menaikan jabatan anggota jika kinerja anggotanya } \\
\text { bagus } \\
\text { Anggota divisi: } \\
\text { - } \quad \text { Mendapatkan job desc } \\
\text { Melaksanakan tugas sesuai dengan job desc }\end{array}$ \\
\hline & & $\begin{array}{l}\text { 36. Ada hubungan } \\
\text { yang baik antara } \\
\text { staf dan penghuni } \\
\text { asrama. }\end{array}$ & $\begin{array}{ll}\text { Premis : } \\
\bullet \quad \text { Ada musyawarah } \\
\text { Pengurus : } \\
\bullet \quad \text { Mengajak santri untuk bergabung } \\
\bullet & \text { Menggunakan usulan santri jika dirasa baik } \\
\text { Santri : } & \\
\bullet & \text { Bergabung ikut musyawarah } \\
\bullet & \text { Berhak berargumen, bertanya dan menyanggah }\end{array}$ \\
\hline & & $\begin{array}{l}\text { 37.Privasi pribadi } \\
\text { penghuni } \\
\text { dihormati }\end{array}$ & $\begin{array}{ll}\text { Pengurus : } \\
\bullet & \text { Pengurus membagi kamar } \\
\bullet & \text { Membuat peraturan mengenai privasi pribadi santri } \\
\bullet & \text { Memvalidasi laporan } \\
\bullet & \text { Memberi sanksi bagi santri yang melanggar } \\
\text { Santri : } & \\
\bullet & \text { Santri mendapat pembagian kamar } \\
- & \text { Santri lain dilarang masuk ke kamar } \\
- & \text { Santri penghuni kamar melapor ke pengurus jika ada } \\
\text { santri lain masuk kamar santri }\end{array}$ \\
\hline & & $\begin{array}{l}\text { 38.Ada seleksi } \\
\text { ketat dan } \\
\text { pemeriksaan } \\
\text { semua staf dan } \\
\text { relawan yang } \\
\text { bekerja } \\
\text { dengannya } \\
\text { asrama }\end{array}$ & $\begin{array}{l}\text { Pimpinan asrama : } \\
\text { - } \quad \text { Merekrut staf baru yang berkualitas } \\
\text { Memeriksa data diri calon staf baru } \\
\text { - } \quad \text { Jika ada catatan kriminal maka calon staf tidak lolos } \\
\text { - } \quad \text { Jika tidak ada catatan kriminal maka masuk ke tahap } \\
\text { wawancara } \\
\text { - Menyeleksi berdasarkan hasil wawancara } \\
\text { - } \quad \text { Menentukan keputusan } \\
\text { Calon staf baru : } \\
\text { - Mendaftar dan menyerah kan berkas pendaftaran } \\
\text { - Calon staf tidak memiliki catatan kriminal, maka } \\
\text { melakukan seleksi wawancara } \\
\text { - Menerima keputusan }\end{array}$ \\
\hline & & $\begin{array}{l}\text { 39. Akses orang } \\
\text { dewasa ke asrama } \\
\text { dan akomodasi }\end{array}$ & $\begin{array}{l}\text { Pengurus: } \\
\bullet \quad \text { Membuat aturan } \\
\bullet \quad \text { Jika pengurus punya ijin masuk kamar maka } \\
\text { diperbolehkan masuk kamar. Jika tidak boleh maka diberi sanksi } \\
\text { Direktur : } \\
\text { - Memberi sanksi pengurus yang melanggar }\end{array}$ \\
\hline 5 & Premis & $\begin{array}{l}\text { 40.Akomodasi } \\
\text { asrama }\end{array}$ & $\begin{array}{ll}\text { Pengurus : } \\
\bullet & \text { Menyediakan fasilitas asrama } \\
\bullet & \text { Menerima laporan kerusakan fasilitas. } \\
\bullet & \text { Menindaklanjuti laporan } \\
\bullet & \text { Melakukan tindakan rehabilitasi fasilitas } \\
\text { Santri : } & \\
\bullet & \text { Menjaga kebersihan di seluruh lingkungan asrama } \\
\bullet & \text { Menjaga dan merawat semua fasilitas asrama dengan } \\
\text { baik. } & \\
\bullet & \text { Melaporkan fasilitas asrama yang rusak secara tertulis }\end{array}$ \\
\hline
\end{tabular}




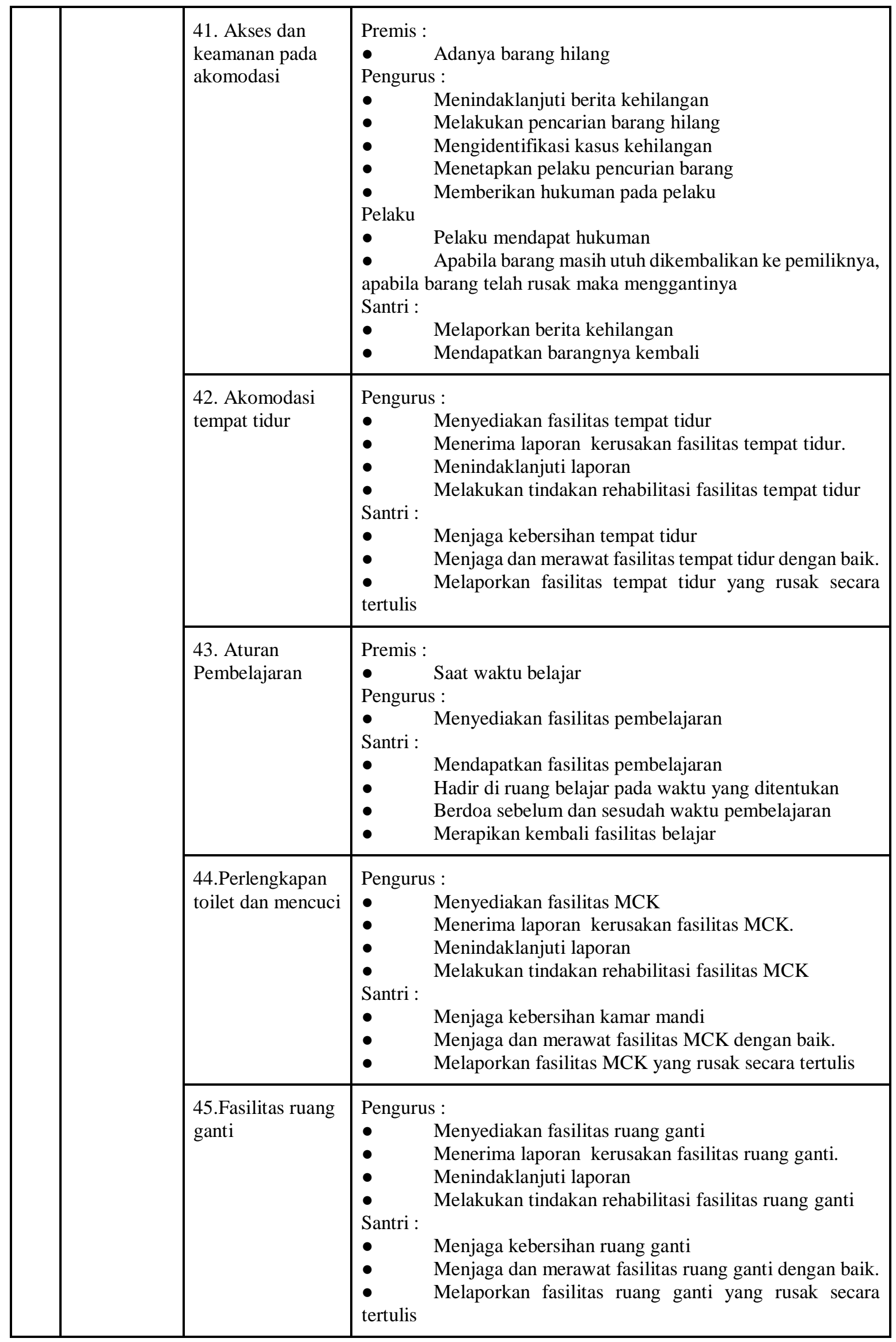




\begin{tabular}{|c|c|}
\hline $\begin{array}{l}\text { 46.Tempat } \\
\text { rekreasi }\end{array}$ & $\begin{array}{ll}\text { Pengurus : } \\
\text { - } & \text { Menyediakan fasilitas rekreasi } \\
\text { - } & \text { Menerima laporan kerusakan fasilitas rekreasi. } \\
\text { - } & \text { Menindaklanjuti laporan } \\
\text { Santri : } & \text { Melakukan tindakan rehabilitasi fasilitas rekreasi } \\
& \\
- & \text { Menjaga kebersihan tempat rekreasi } \\
- & \text { Menjaga dan merawat fasilitas rekreasi dengan baik. } \\
\text { - } & \text { Melaporkan fasilitas rekreasi yang rusak secara tertulis }\end{array}$ \\
\hline $\begin{array}{l}\text { 47. Bahaya } \\
\text { keselamatan dan } \\
\text { penilaian risiko }\end{array}$ & 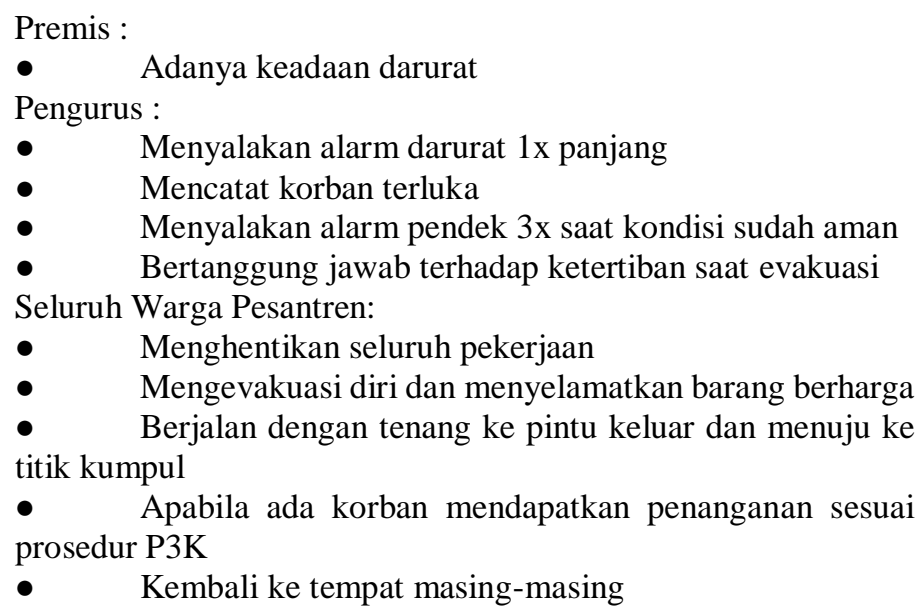 \\
\hline $\begin{array}{l}\text { 48.Akomodasi } \\
\text { untuk murid yang } \\
\text { sakit }\end{array}$ & $\begin{array}{ll}\text { Premis : } \\
\bullet & \text { Santri sakit } \\
\text { Pengurus : } \\
\bullet \quad \text { Menyediakan fasilitas penanganan santri sakit } \\
\bullet & \text { Memeriksa fasilitas penunjang rehabilitasi santri yang } \\
\text { sakit } & \\
\bullet & \text { Memeriksa ketersedian obat } \\
\bullet & \text { Menerima laporan santri yang sakit. } \\
\bullet & \text { Melakukan tindakan santri yang sakit } \\
\text { Santri : } & \text { Menjaga fasilitas penanganan santri sakit } \\
\bullet & \text { Menerima akomodasi yang memadai apabila mengalami } \\
\bullet & \end{array}$ \\
\hline 49. Laundry & $\begin{array}{ll}\text { Pengurus : } \\
\text { - } & \text { Menyediakan fasilitas laundry } \\
\text { Santri : } & \text { Menandatangani catatan pakaian laundry } \\
\text { - } & \text { Me laundry pakaian } \\
\text { - } & \text { Pakaian berat dapat di laundry sebulan } 2 \text { kali atau } \\
\text { menyesuaikan pihak laundry } \\
\text { - } \quad \text { Mencatat semua pakaian yang dilaundry }\end{array}$ \\
\hline $\begin{array}{l}50 . \text { Alat tulis dan } \\
\text { barang pribadi }\end{array}$ & $\begin{array}{ll}\text { Pengurus : } \\
\text { - } & \text { Menyediakan fasilitas loker } \\
- & \text { Menerima laporan kerusakan fasilitas loker. } \\
\text { - } & \text { Menindaklanjuti laporan } \\
\text { Santri : } & \text { Melakukan tindakan rehabilitasi fasilitas loker } \\
& \\
- & \text { Menjaga kebersihan loker } \\
- & \text { Menjaga dan merawat fasilitas loker dengan baik. } \\
\text { - } & \text { Melaporkan fasilitas asrama yang rusak secara tertulis }\end{array}$ \\
\hline
\end{tabular}




\begin{tabular}{|c|c|c|c|}
\hline & 51. Penginapan & $\begin{array}{l}\text { Premis: } \\
\text { - } \quad \text { Adanya santri baru } \\
\text { Pengurus: } \\
\text { - } \quad \text { Menyediakan pemondokan yang layak bagi santri } \\
\text { - } \quad \text { Mengatur pembagian kamar bagi santri sesuai kapasitas } \\
\text { Santri baru: } \\
\text { - } \quad \text { Santri menempati kamar yang telah ditentukan } \\
\text { - Santri menjaga dan merawat fasilitas yang telah } \\
\text { didapatkan }\end{array}$ \\
\hline & & $\begin{array}{l}\text { 52. Akomodasi } \\
\text { dan pertukaran di } \\
\text { luar lokasi }\end{array}$ & 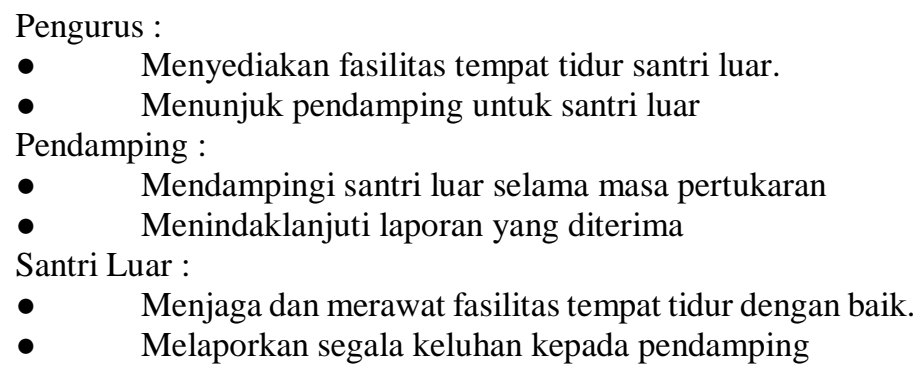 \\
\hline
\end{tabular}

Tabel 2 tersebut merupakan sebuah wbs hasil yang terdiri dari aktivitas-aktivitas dari setiap standar nya. terdapat 52 standar sehingga didapatkan 52 WBS. WBS ini menurunkan standar menjadi detail aktivitas yang harus dilakukan oleh setiap aktor yang terlibat. Untuk langkah selanjutnya adalah membuat proses bisnis dari WBS berdasarkan Tabel 2 tersebut.

\section{HASIL DAN PEMBAHASAN}

Langkah pada penelitian ini meliputi studi literatur Sekolah Standar Asrama dan WBS. Pada penelitian ini kami menggunakan wbs, sehingga dari tabel 2 kami gunakan sebagai bahan untuk pemodelan selanjutnya. Pada Sekolah Standar Asrama terdapat 5 point umum diantaranya kebijakan dan prosedur kesejahteraan, organisasi dan manajemen, dukungan kesejahteraan kepada dewan, staffing, dan premis. Poin-poin umum Sekolah standar asrama tersebut nantinya akan dimodelkan sesuai dengan aktivitasnya.

\section{Pembuatan, Hasil dan Pembahasan Proses Bisnis}

Berdasarkan 52 Standar SSA pada yang telah peneliti bahas pada bab sebelumnya, peneliti telah merumuskan 52 proses bisnis pondok pesantren sebagai berikut:

1. Pernyataan prinsip dan praktik asrama

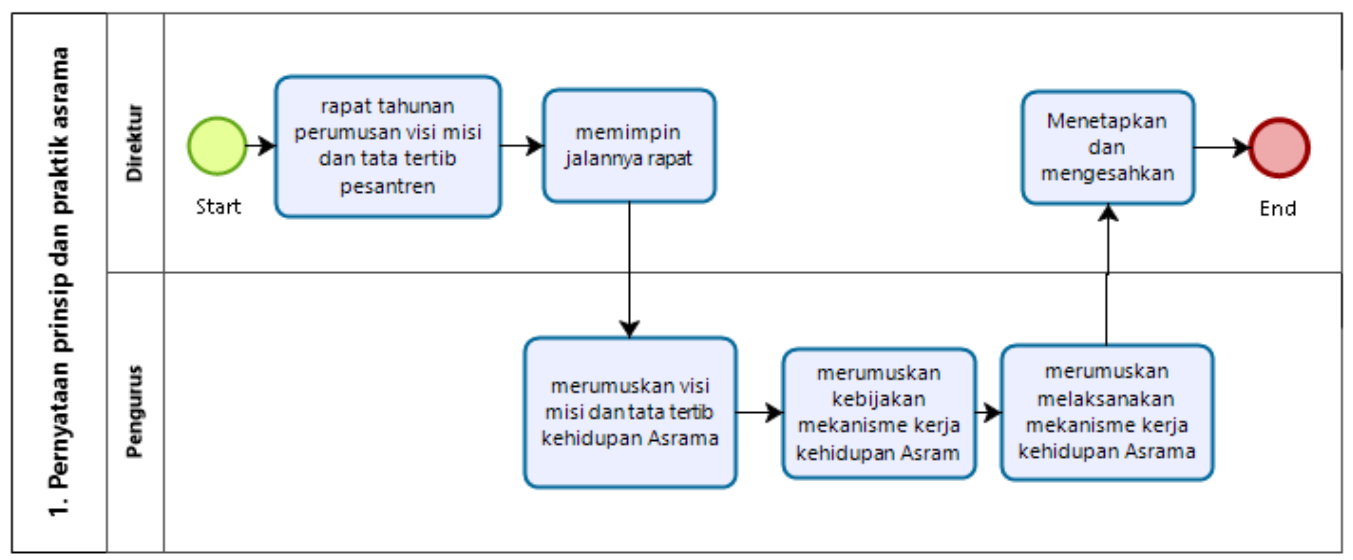


Gambar 2. Model Proses bisnis standar pernyataan prinsip dan praktik asrama

Gambar 2 merupakan model proses bisnis pada standar ke-1 yakni standar pernyataan prinsip dan praktik asrama. Dari gambar 2 tersebut dapat dideskripsikan Direktur memimpin rapat tahunan untuk menetapkan visi misi dan tata tertib pesantren. Kemudian pengurus merumuskan visi misi dan tata tertib pesantren dan kebijakan mekanisme kerja kehidupan asrama serta melaksanakannya. Dan direktur menetapkan dan mengesahkan rumusanrumusan yang telah disepakati.

2. Melawan penindasan (asrama dilindungi dari intimidasi)

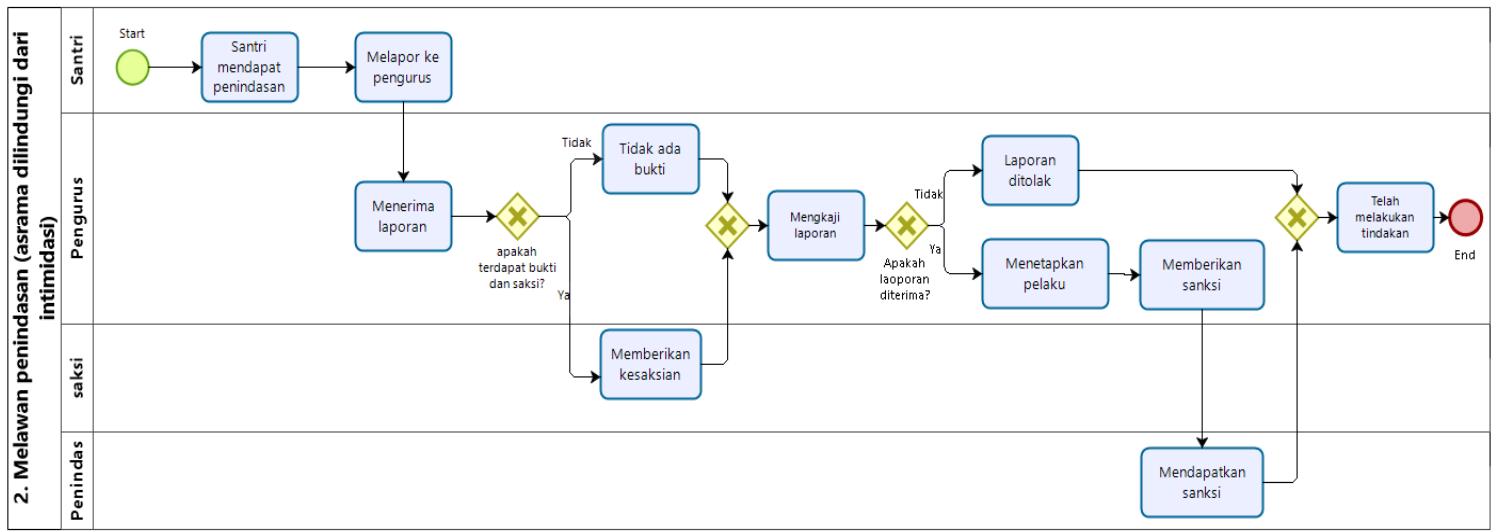

Gambar 3. Model Proses bisnis standar pernyataan prinsip dan praktik asrama

Gambar 3 merupakan proses bisnis yang menggambarkan prosedur tindakan melawan penindasan (standar 2). Adapun deskripsi dari gambar tersebut dimulai dari santri mendapat penindasan sebagai keadaan awal, Santri yang menjadi korban harus melapor ke pengurus yang nantinya akan menindak lanjuti laporan. Kemudian pengurus memvalidasi laporan dengan mempelajari saksi dan bukti. jika laporan valid maka pelaku yang telah disebutkan dan terbukti akan diberi sanksi.

\section{Perlindungan anak}

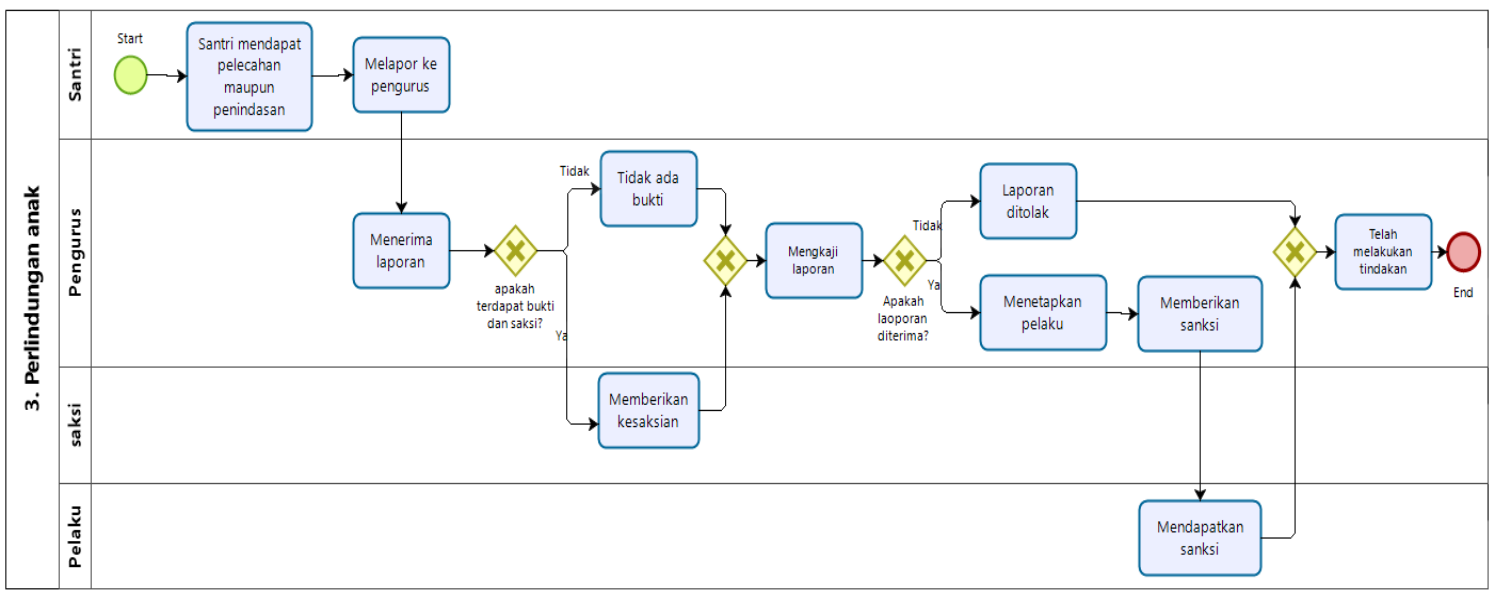

Gambar 4. Model Proses bisnis standar perlindungan anak

Gambar 4 merupakan Proses bisnis yang menggambarkan prosedur perlindungan anak. deskripsi dari gambar 4 tersebut adalah dimulai dari santri mendapat penindasan sebagai keadaan awal, Santri yang menjadi korban harus melapor ke pengurus yang nantinya akan menindak lanjuti laporan. Pengurus menjaga kerahasiaan korban [11]. Kemudian pengurus 
memvalidasi laporan dengan mempelajari saksi dan bukti. jika laporan valid maka pelaku yang telah disebutkan dan terbukti akan diberi sanksi.

4. Perilaku, disiplin, hukuman, penghargaan dan pengekangan

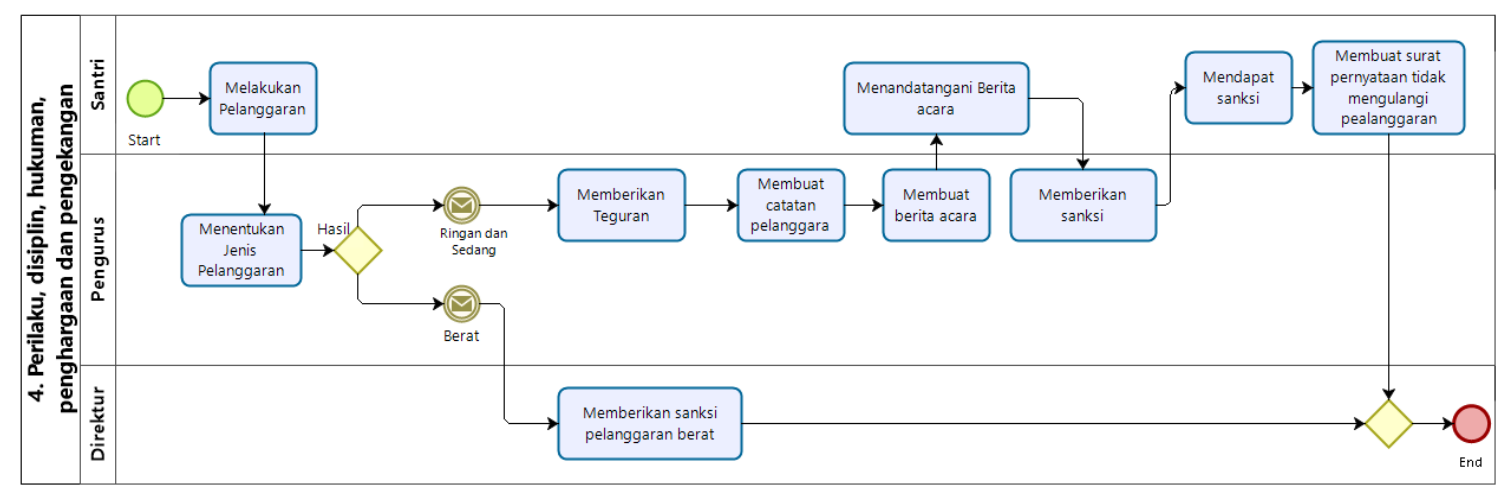

Gambar 5. Model Proses bisnis standar perilaku, disiplin, hukuman, penghargaan dan pengekangan

Gambar 5 tersebut merupakan Proses bisnis dari standar ke 4, yang menggambarkan prosedur tindakan pemberian sanksi terhadap pelanggaran santri. Deskripsi dari gambar tersebut dimulai dari santri melakukan pelanggaran, Santri melakukan pelanggaran ringan diberi teguran ataupun sanksi dan dicatat oleh pengurus. Setelah mendapatkan sanksi pelanggar diwajibkan membuat surat pernyataan untuk tidak mengulangi lagi. jika pelanggaran berat maka diberikan sanksi pelanggaran berat.

5. Menanggapi keluhan (keluhan asrama ditanggapi dengan memadai)

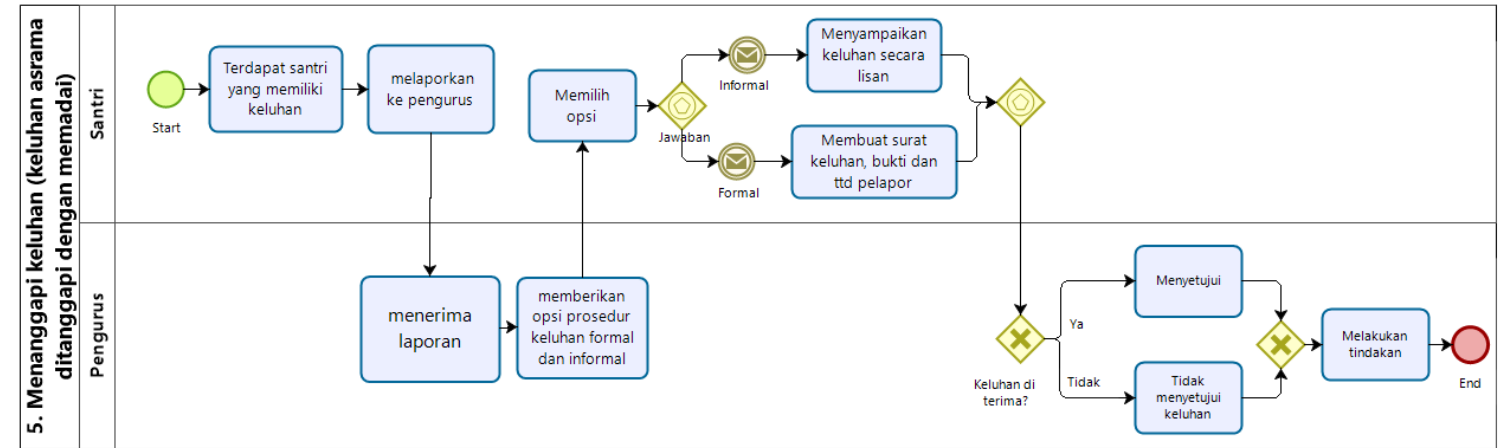

Gambar 6. Model Proses bisnis standar menanggapi keluhan (keluhan asrama ditanggapi dengan memadai)

Gambar 6 tersebut merupakan Proses bisnis standar ke 5 yang menggambarkan prosedur menangani keluhan. Dimulai dari santri memiliki keluhan, Santri yang memiliki keluhan melaporkan ke pengurus. Kemudian pengurus memvalidasi keluhan. jika keluhan diterima maka pengurus melakukan tindakan atas keluhan santri. 
6. Kesehatan asrama ditingkatkan

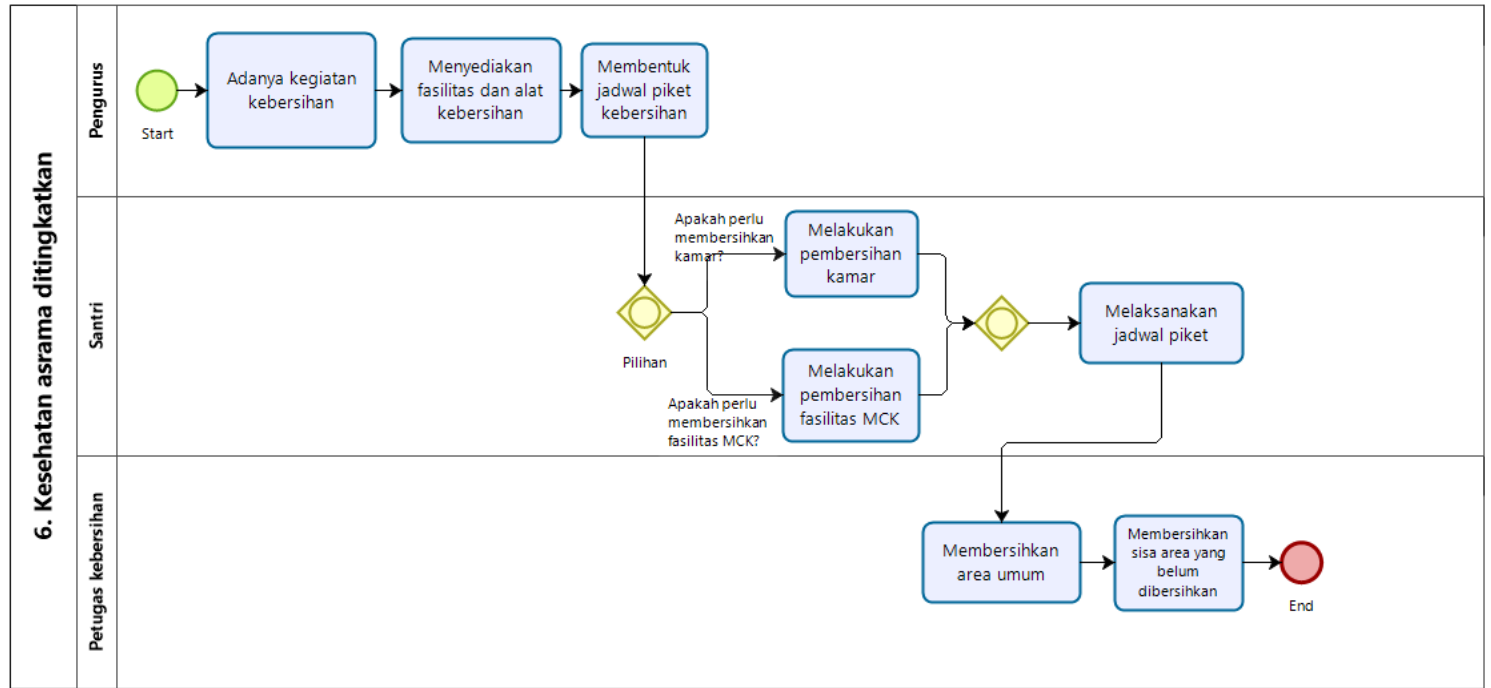

Gambar 7. Model Proses bisnis standar kesehatan asrama ditingkatkan

Gambar 7 menggambarkan prosedur peningkatan kebersihan dan kesehatan. Dimulai dari diadakannya kegiatan kebersihan. Pengurus menyediakan fasilitas dan alat kebersihan. kemudian pengurus membentuk piket kebersihan diantaranya adalah pembersihan kamar dan pembersihan MCK. Santri dapat membersihkan kedua lokasi tersebut. jika ada halangan untuk santri membersihkan wilayah piket tersebut maka dapat digantikan oleh petugas kebersihan. selain itu petugas kebersihan juga membersihkan wilayah umum selain wilayah yang diatur oleh piket.

\section{Catatan kesehatan penghuni asrama}

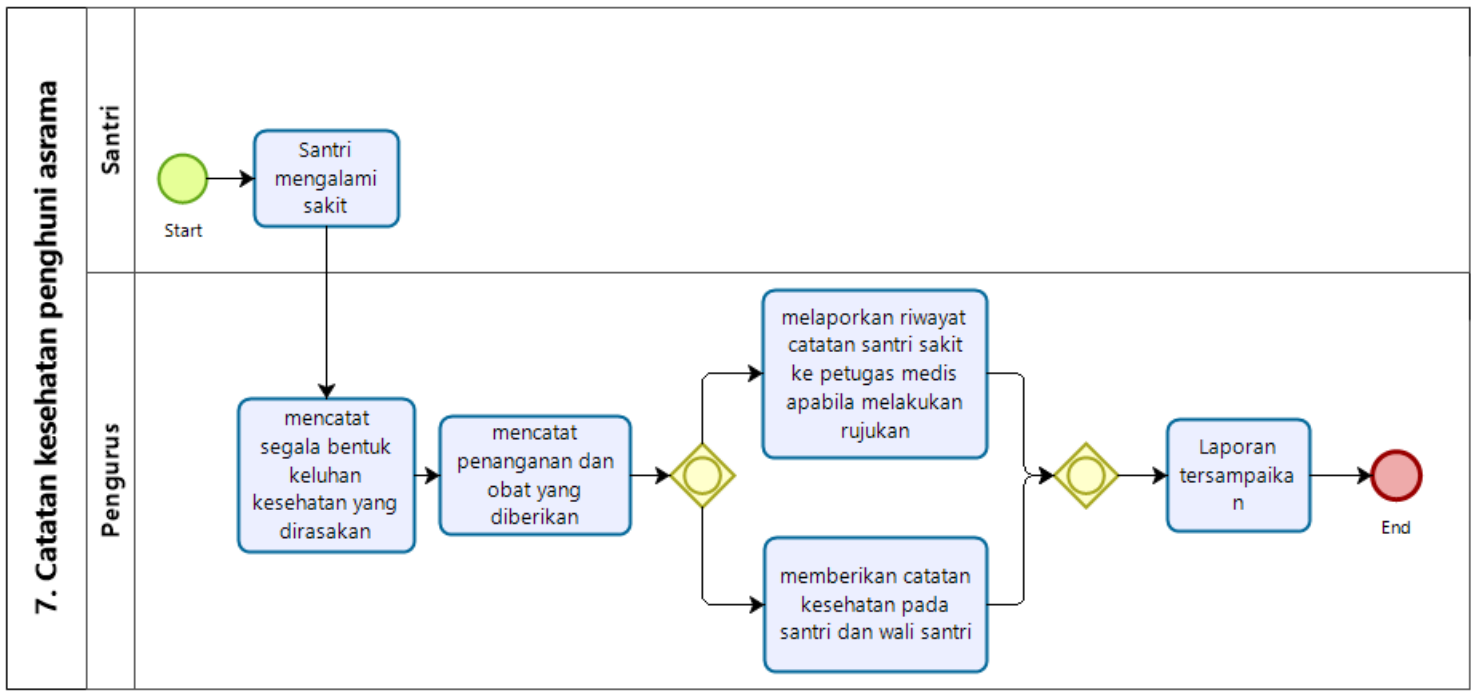

Gambar 8. Model Proses bisnis standar catatan kesehatan penghuni asrama

Gambar 8 menggambarkan prosedur pencatatan kesehatan santri. Dimulai dari santri mengalami sakit. Kemudian pengurus mencatat setiap keluhan dan perkembangan kesehatan santri serta obat yang telah diberikan. jika dibutuhkan rujukan ke faskes lanjutan maka catatan kesehatan ditunjukan ke petugas faskes tersebut. catatan kesehatan juga diberikan kepada santri dan wali santri. 
8. Ada kepemimpinan yang jelas dari pesantren

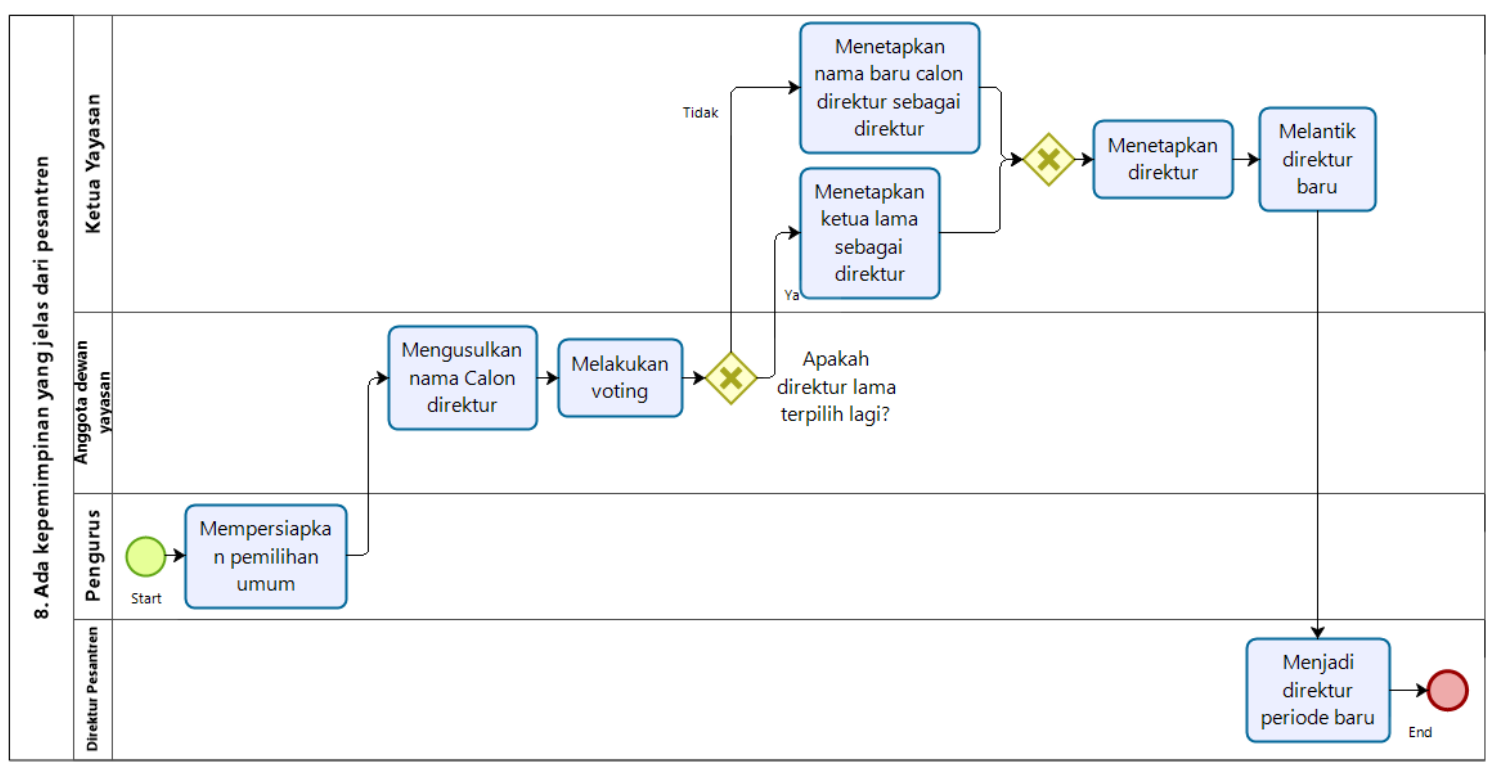

Gambar 9. Model Proses bisnis standar ada kepemimpinan yang jelas dari pesantren

Gambar 9 menggambarkan prosedur pemilihan pimpinan. pengurus periode sebelumnya mempersiapkan pemilihan umum. anggota dewan yayasan mengusulkan nama calon direktur dan melakukan voting. ketua yayasan menetapkan ketua dan melantik direktur periode baru.

\section{Manajemen Krisis}

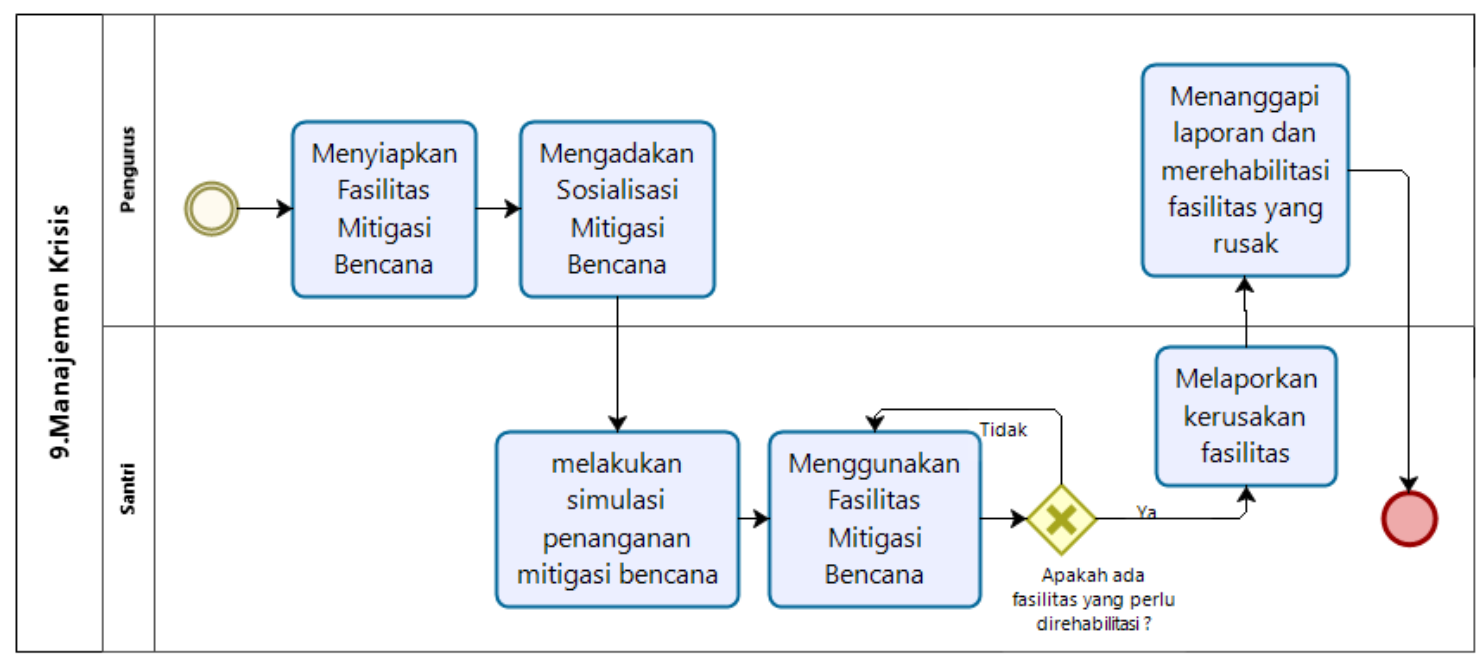

Gambar 10. Model Proses bisnis standar manajemen krisis

Gambar 10 menggambarkan prosedur manajemen krisis. Pengurus menyiapkan fasilitas mitigasi bencana dan mengadakan sosialisasi mengenai mitigasi bencana kepada para santri. para santri melakukan simulasi penanganan mitigasi bencana. para santri menjaga fasilitas mitigasi bencana. apabila ada kerusakan fasilitas maka segera melaporkan ke pengurus. pengurus segera merehabilitasi fasilitas yang rusak. 
10. Organisasi pesantren berkontribusi pada kesejahteraan para pesantren

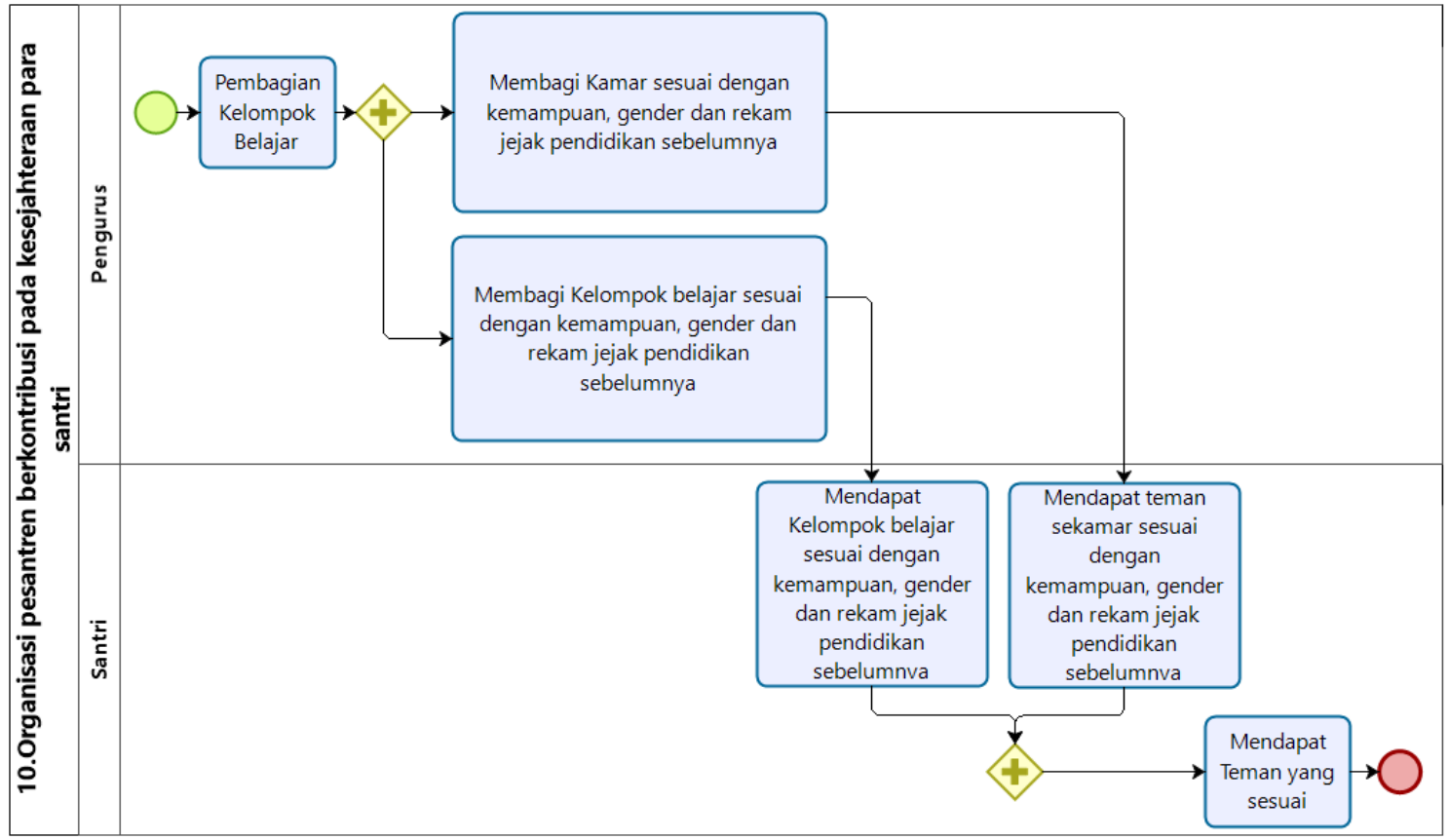

Gambar 11. Model Proses bisnis standar organisasi pesantren berkontribusi pada kesejahteraan para pesantren

Gambar 11 menggambarkan prosedur kontribusi pesantren pada kesejahteraan santri.. pengurus membagi kelompok belajar dan ruang kamar sesuai dengan kemampuan, gender dan rekam jejak pendidikan sebelumnya. dengan demikian santri mendapatkan teman yang sesuai.

11. Kegiatan dan waktu luang

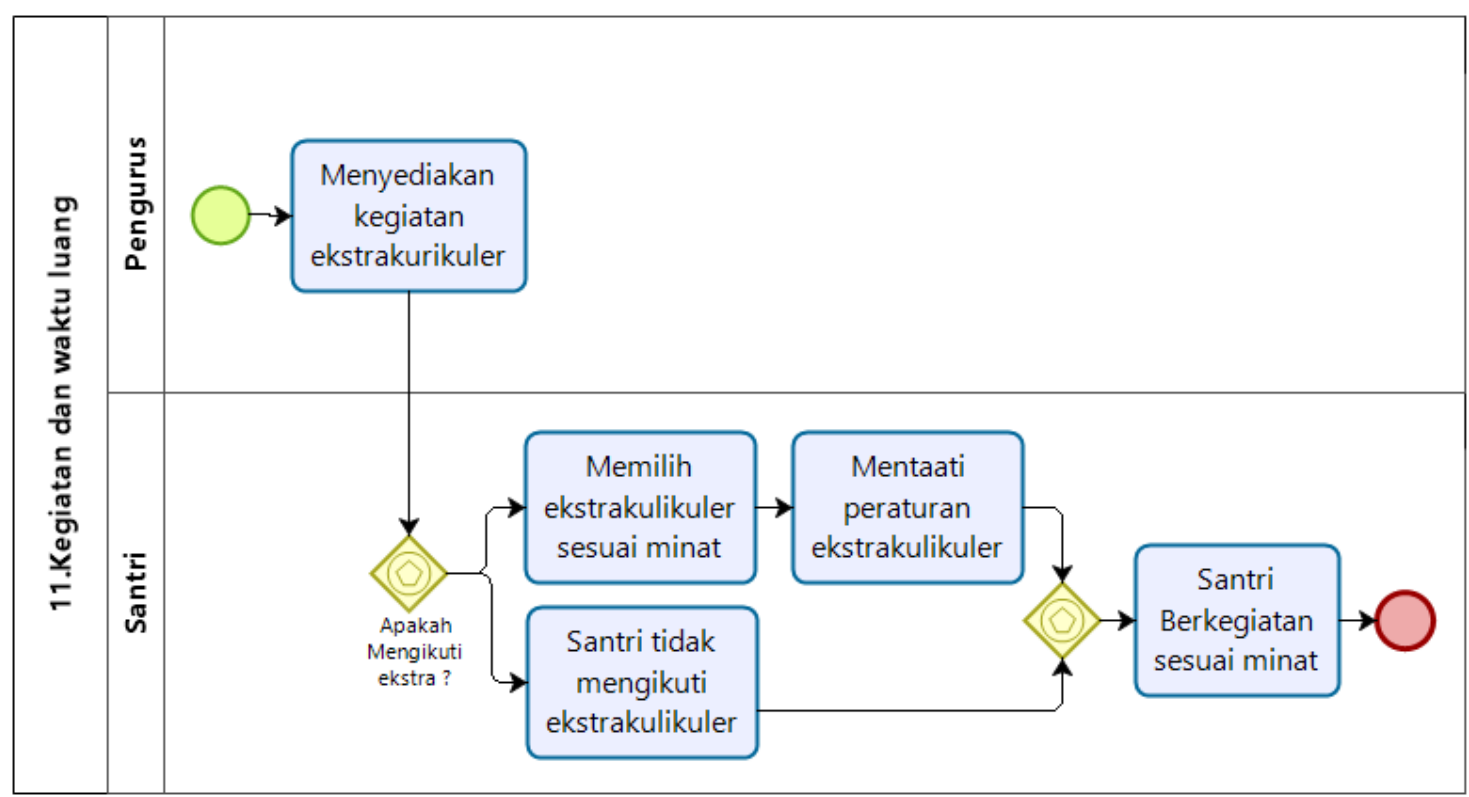

Gambar 12. Model Proses bisnis standar kegiatan dan waktu luang

Gambar 12 menggambarkan prosedur kegiatan waktu luang. Pengurus menyediakan kegiatan ekstrakurikuler. santri berhak mengikuti kegiatan sesuai minat. 
12. Mengamankan pandangan penghuni asrama

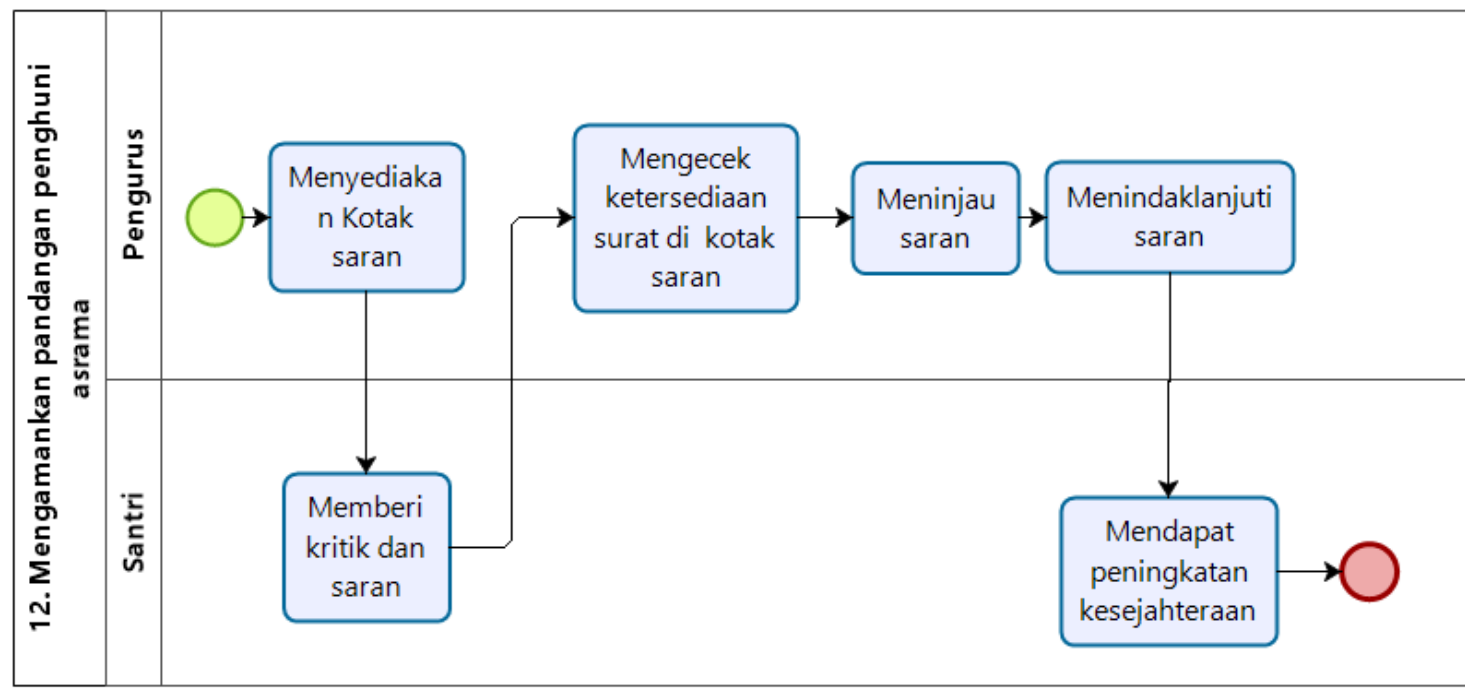

Gambar 13. Model proses bisnis standar mengamankan pandangan penghuni asrama

Gambar 13 menggambarkan prosedur mengamankan pandangan penghuni asrama. pengurus menyediakan kotak saran untuk santri mengisi kritik dan saran. pengurus secara berkala mengecek ketersediaan surat di kotak saran serta meninjau saran dan menindaklanjuti saran sehingga didapatkan peningkatan kesejahteraan santri.

\section{Adanya peran senior}

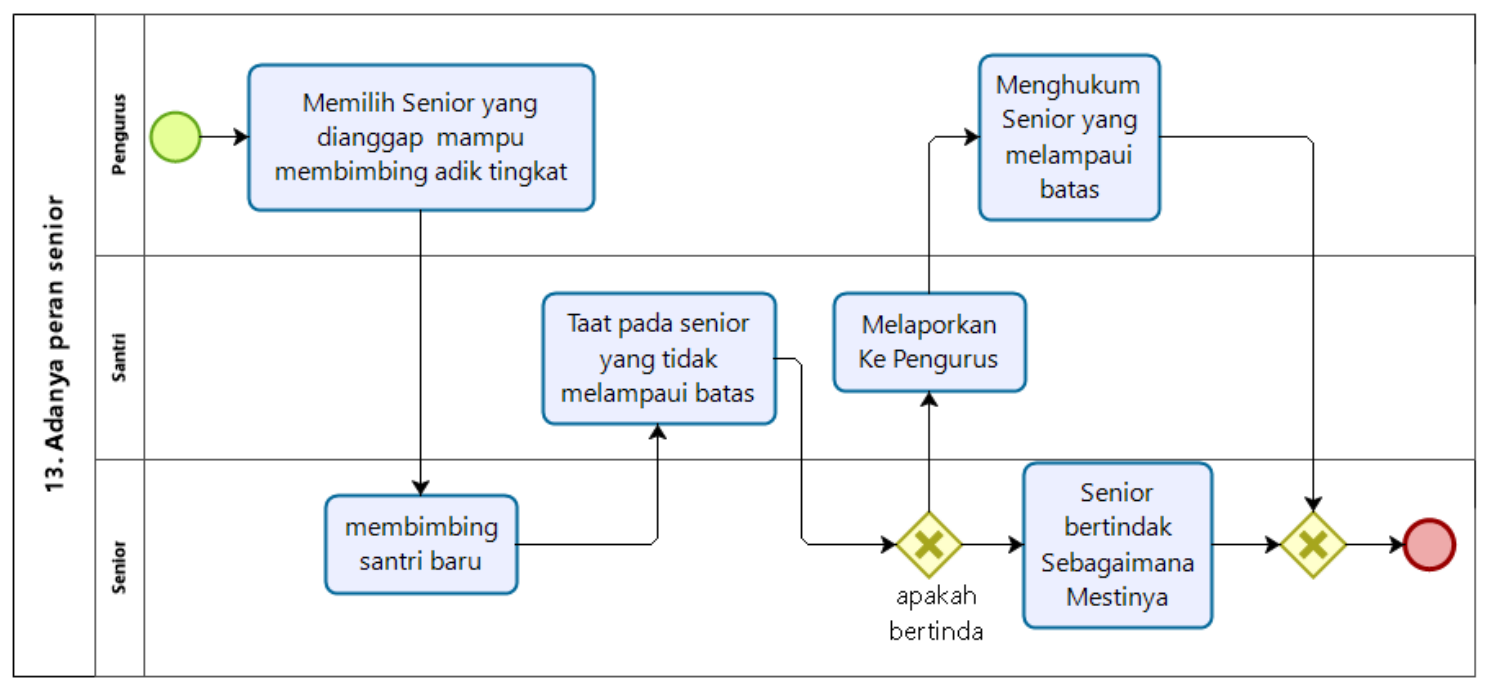

Gambar 14. Model proses bisnis standar adanya peran senior

Gambar 14 menggambarkan prosedur peran senior. Pengurus memilih senior yang dianggap mampu membimbing adik tingkat. senior yang dipilih membimbing adik tingkat dengan tidak melampaui batas. Santri baru taat pada senior dengan jika tidak melampaui batas. jika melampaui batas maka santri baru melaporkan ke pengurus dan pengurus menghukum senior yang melampaui batas. 
14. Staf dan dukungan pihak luar pada santri

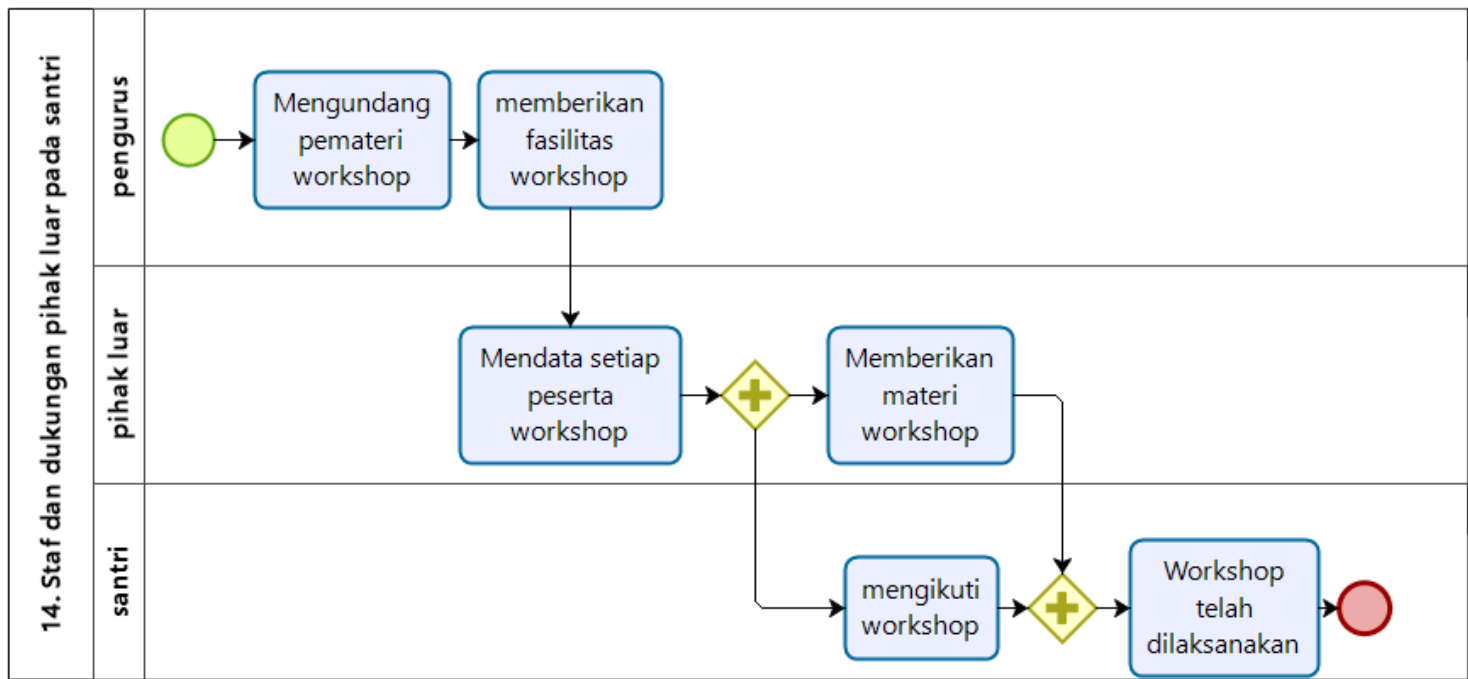

Gambar 15. Model proses bisnis standar staf dan dukungan pihak luar pada santri

Gambar 15 menggambarkan prosedur pengadaan workshop. Pengurus mengadakan workshop dan mengundang pemateri dari luar serta memfasilitasi kegiatan workshop. pihak luar mendata setiap peserta workshop sebelum memberikan materi workshop. ketika workshop berlangsung pemateri memberikan workshop dan para santri mengikuti workshop. apabila santri antusias terhadap workshop maka akan diadakan workshop serupa.

15. Perawatan medis dan pertolongan pertama

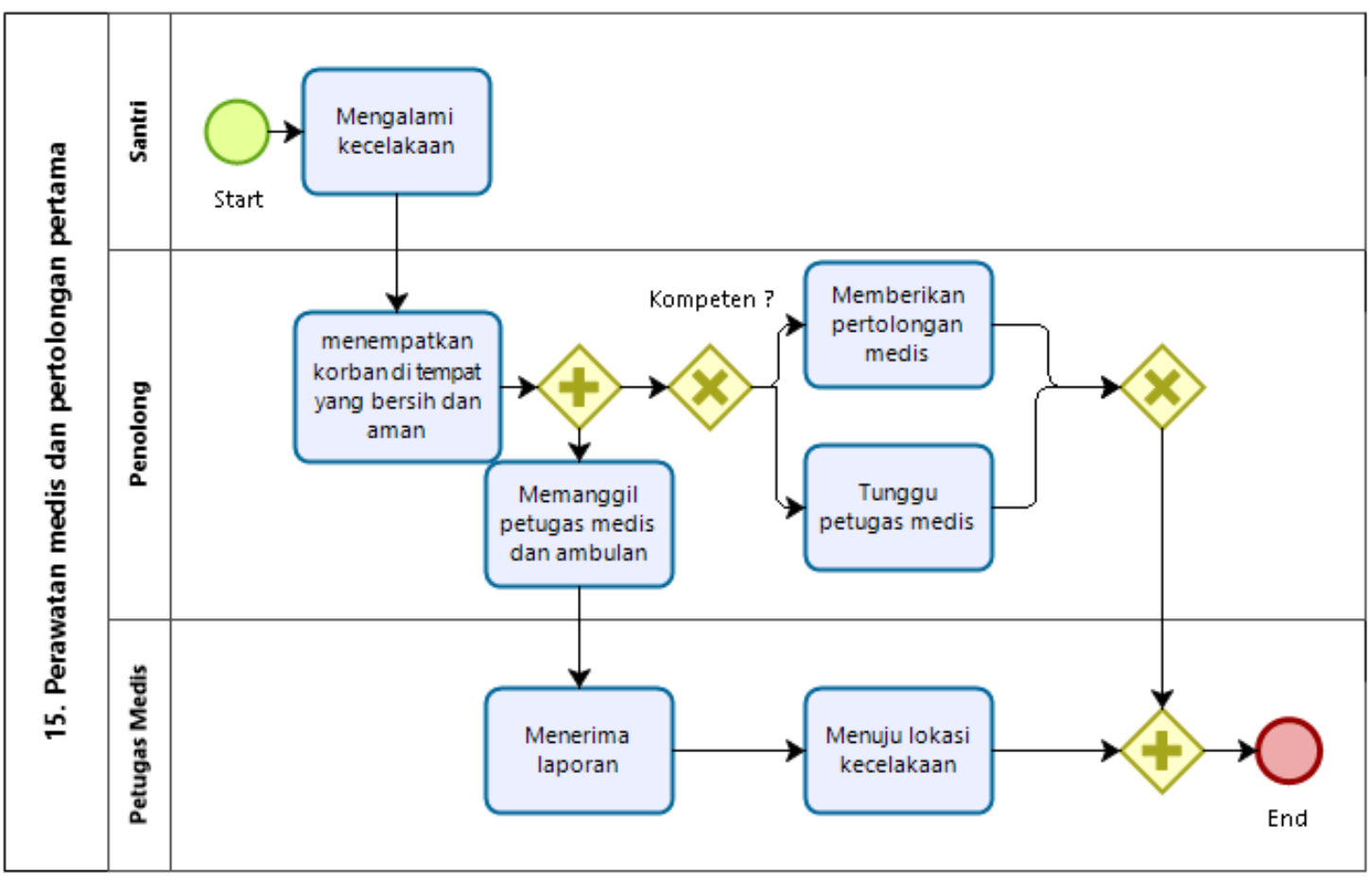

Gambar 16. Model proses bisnis standar perawatan medis dan pertolongan pertama

Gambar 16 menggambarkan prosedur penanganan p3k. Ketika ada santri mengalami kecelakaan penolong menempatkan korban di tempat yang aman dan bersih. kemudian penolong memanggil petugas medis dan ambulans. selagi menunggu petugas medis dengan 
ambulan apabila penolong berkompeten maka melakukan pertolongan pertama. ketika petugas ambulans datang langsung memberi pertolongan pertama lanjutan dan membawa ke faskes.

16. Merawat santri yang sakit

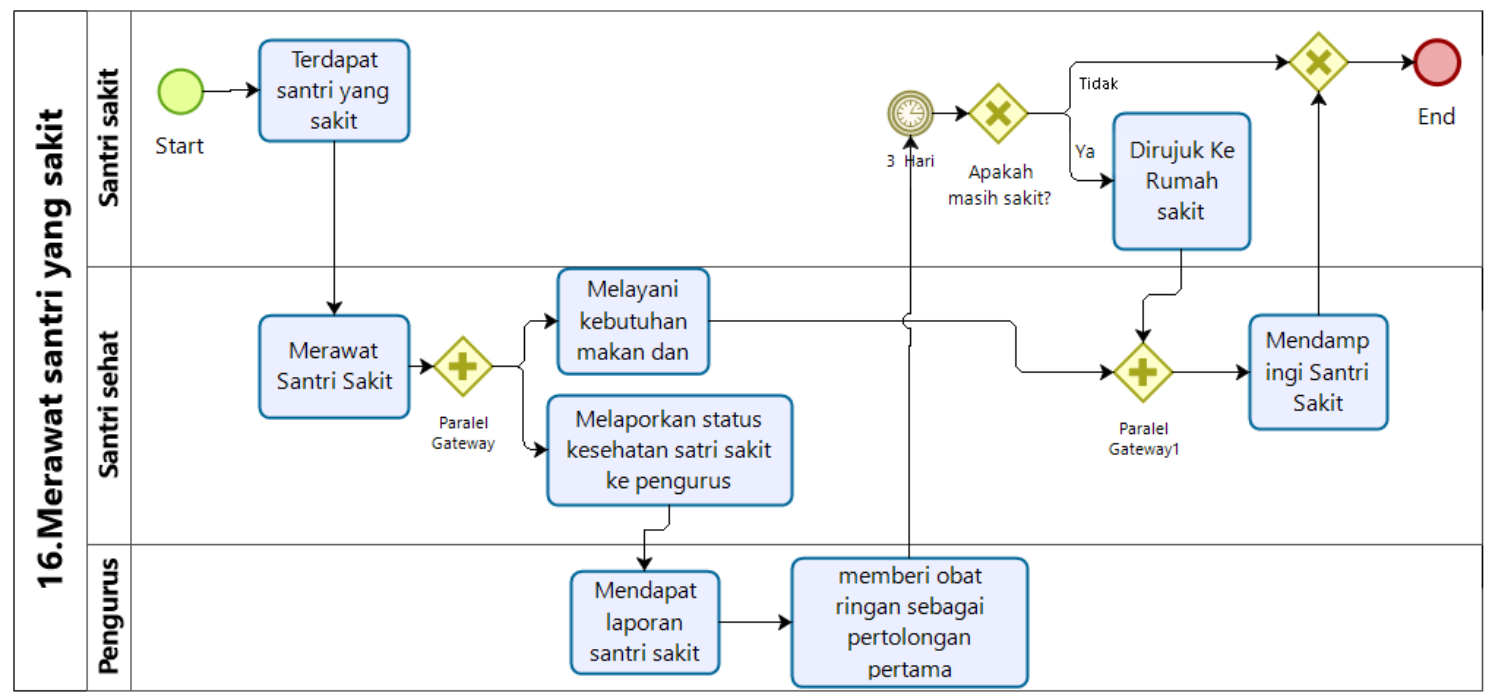

Gambar 17. Model proses bisnis standar merawat santri yang sakit

Gambar 17 menggambarkan prosedur merawat santri yang sakit. Dimulai dari adanya santri yang sakit, Teman santri yang sakit merawat santri yang sakit mengabarkan ke pengurus perihal status kesehatan santri yang sakit. Pengurus memberikan obat ringan sebagai pertolongan pertama. apabila selama 3 hari gejala belum reda maka dirujuk ke rumah sakit. teman santri yang sakit membantu merawat serta mendampingi santri yang sakit.

17. Manajemen Kesehatan dan masalah pribadi

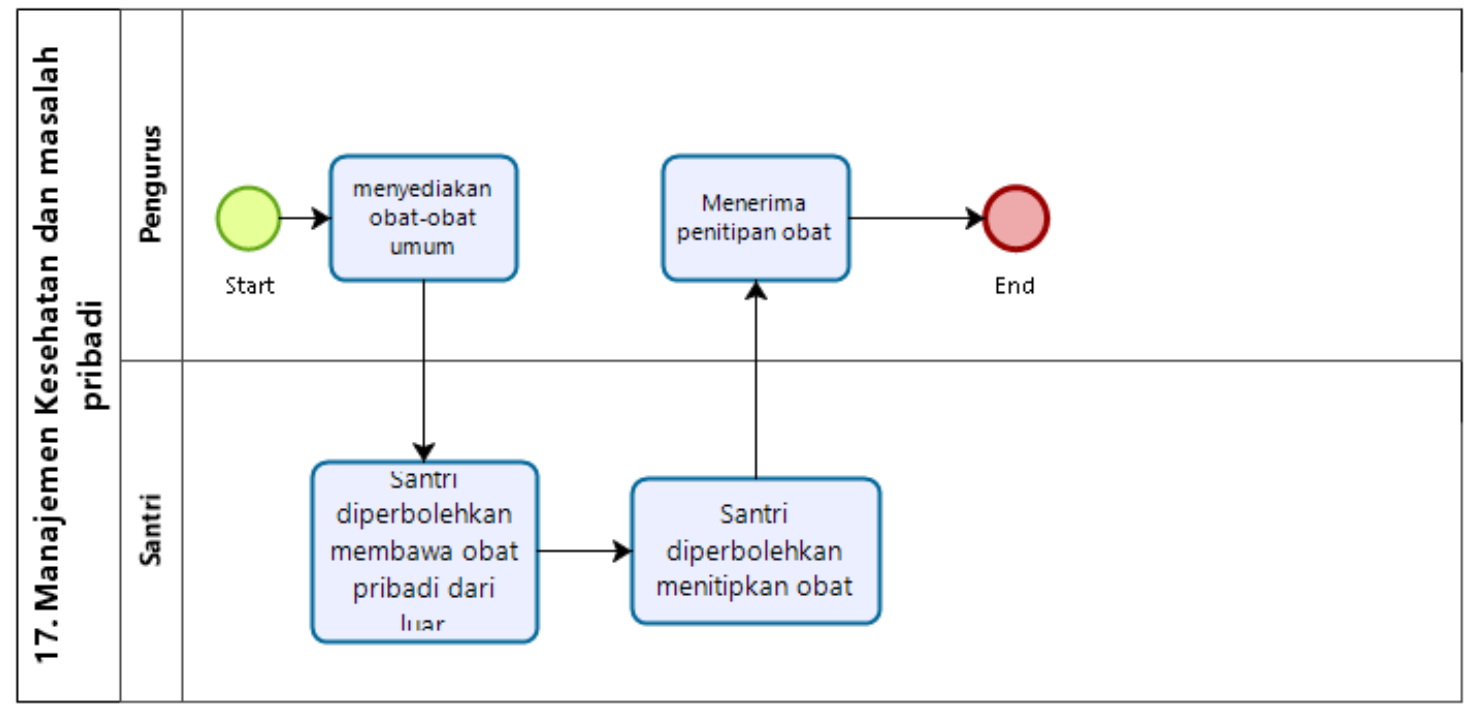

Gambar 18. Model proses bisnis standar manajemen kesehatan dan masalah pribadi 
Gambar 18 menggambarkan prosedur manajemen kesehatan pribadi. Pengurus menyediakan obat-obat umum. Santri diperbolehkan membawa obat pribadi dari luar. apabila obat tersebut berpotensi disalahgunakan teman lain maka dititipkan ke pengurus.

18. Diskriminasi dan persamaan kesempatan

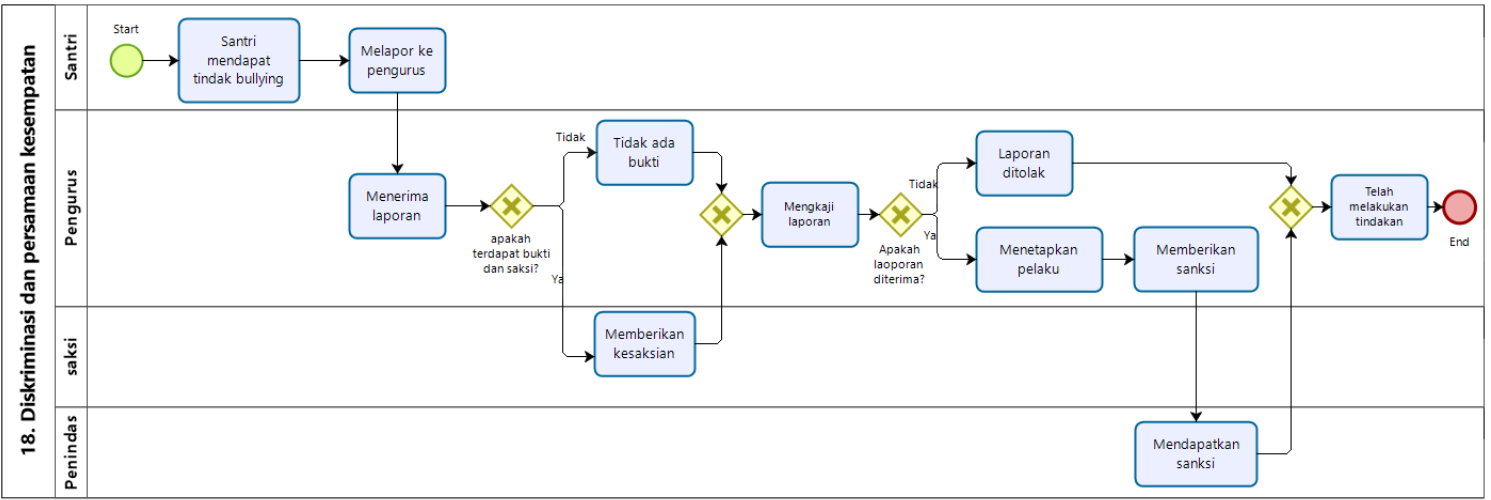

Gambar 19. Model proses bisnis standar diskriminasi dan persamaan kesempatan

Gambar 19 menggambarkan prosedur tindakan melawan penindasan. Dimulai dari santri mendapat penindasan sebagai keadaan awal, Santri yang menjadi korban harus melapor ke pengurus yang nantinya akan menindak lanjuti laporan. Kemudian pengurus memvalidasi laporan dengan mempelajari saksi dan bukti. jika laporan valid maka pelaku yang telah disebutkan dan terbukti akan diberi sanksi.

19. Penghuni asrama dapat menjaga kontak pribadi dengan orang tua dan keluarga mereka

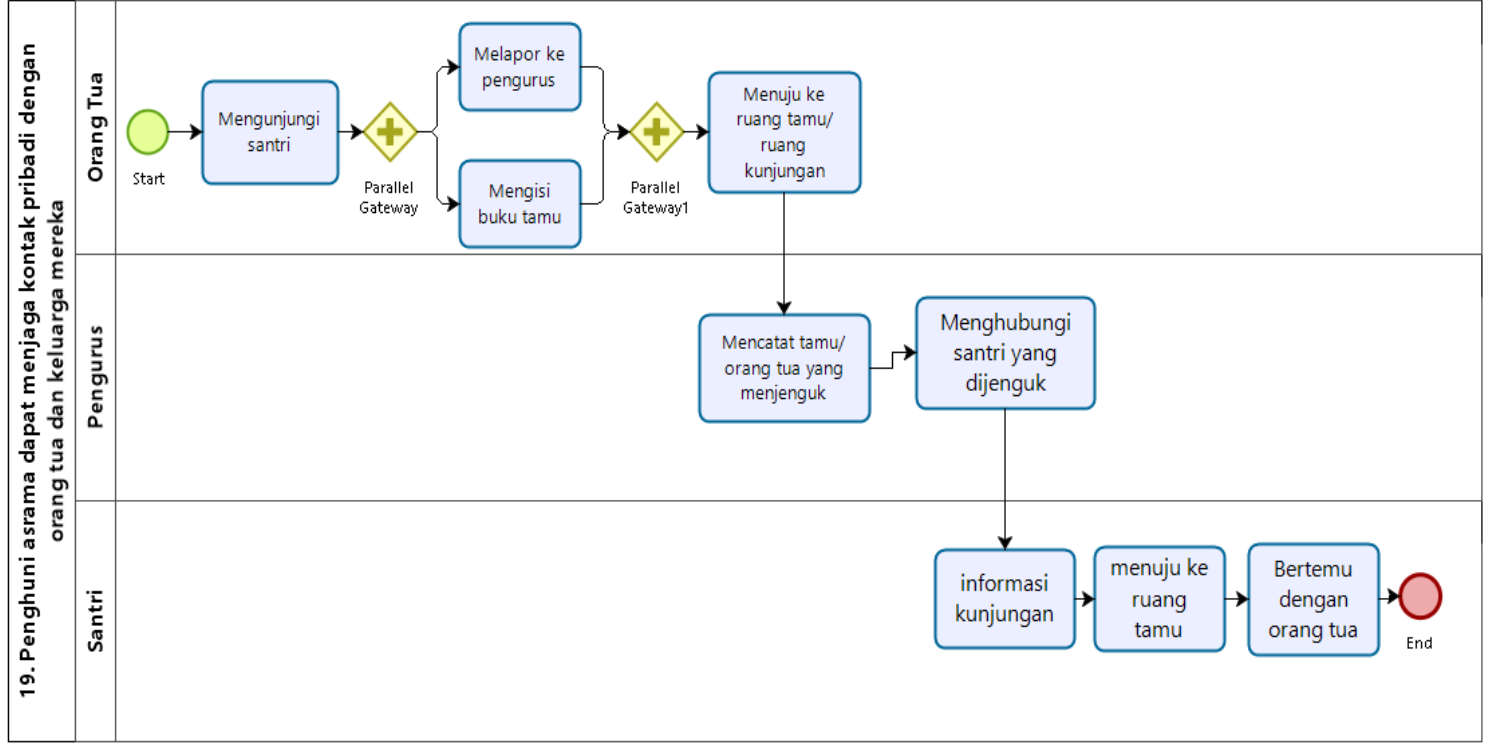

Gambar 20. Model proses bisnis standar penghuni asrama dapat menjaga kontak pribadi dengan orang tua dan keluarga mereka

Gambar 20 menggambarkan prosedur kunjungan wali santri. Dimulai dari wali santri mengunjungi santri. wali santri diwajibkan melapor ke pengurus serta mengisi buku tamu. untuk menjenguk santri, wali santri menuju ke ruang kunjungan. Selanjutnya pengurus menginformasikan kepada santri bahwasanya ada kunjungan. 
20. Harta dan uang penghuni asrama dilindungi

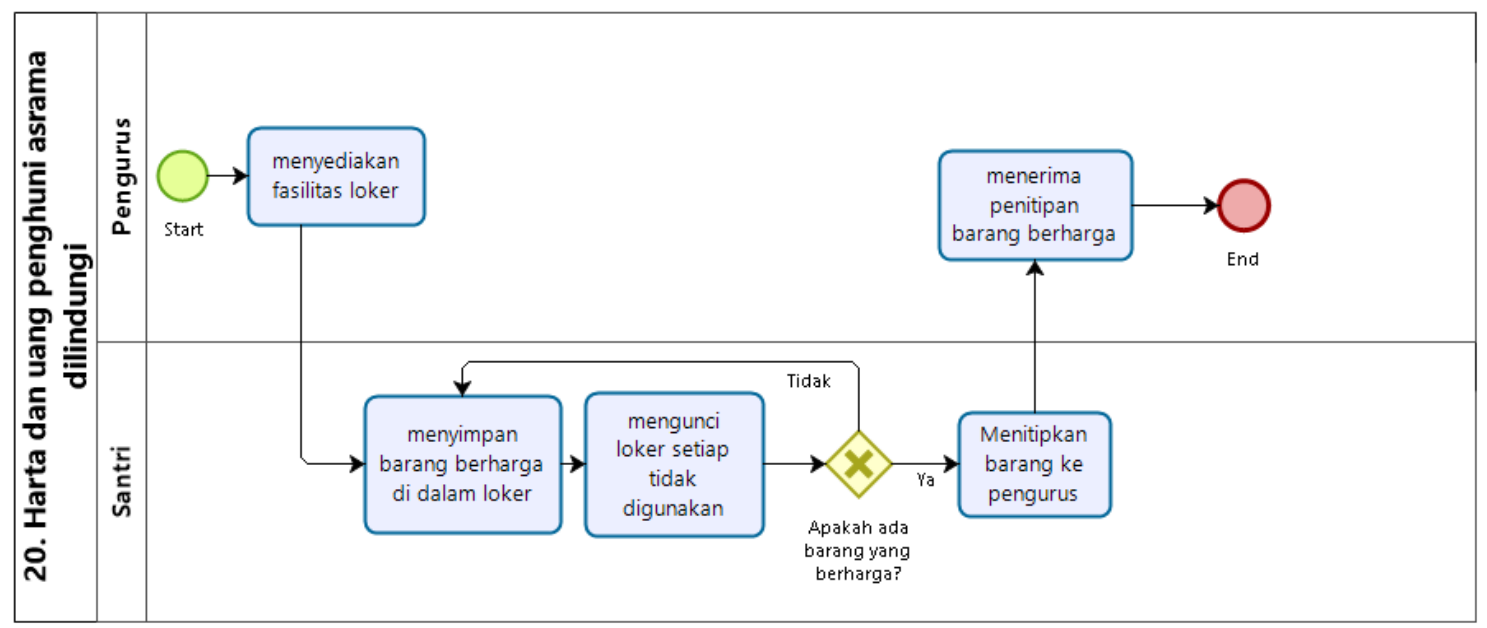

Gambar 21. Model proses bisnis standar Harta dan uang penghuni asrama dilindungi

Gambar 21 menggambarkan prosedur tindakan melawan penindasan. Dimulai dari santri mendapat penindasan sebagai keadaan awal, Santri yang menjadi korban harus melapor ke pengurus yang nantinya akan menindak lanjuti laporan. Kemudian pengurus memvalidasi laporan dengan mempelajari saksi dan bukti. jika laporan valid maka pelaku yang telah disebutkan dan terbukti akan diberi sanksi.

\section{Pengenalan santri baru}

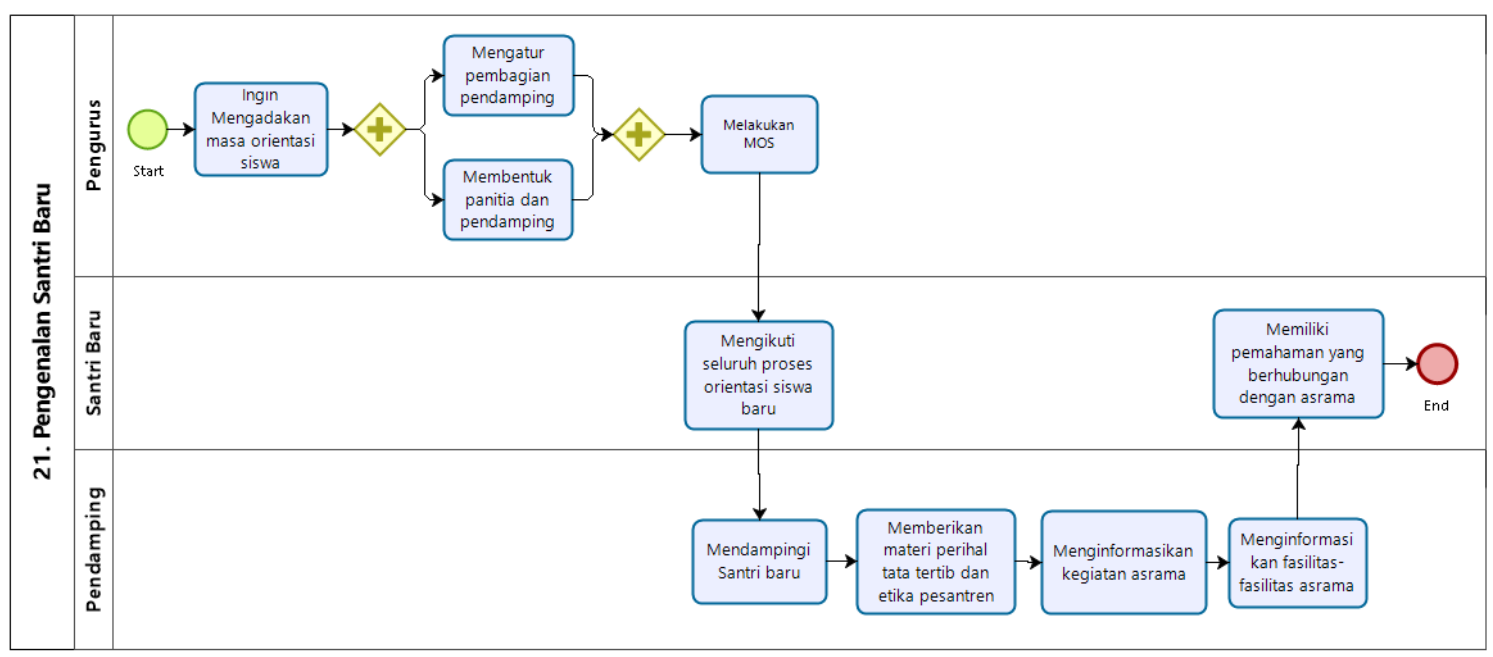

Gambar 22. Model proses bisnis standar pengenalan santri baru

Gambar 22 menggambarkan prosedur pengenalan santri baru. Dimulai dari santri Panitia akan mengadakan masa orientasi santri. Kemudian pengurus membagi pendamping dan panitia. ketika masa orientasi santri diadakan santri baru wajib mengikuti seluruh rangkaian kegiatan. pendamping yang ditugaskan mendampingi santri baru memberikan materi perihal tata tertib dan etika pesantren serta kegiatan asrama, selain itu disebutkan pula fasilitas asrama dan cara perawatannya. 
22. Wali Pendidikan

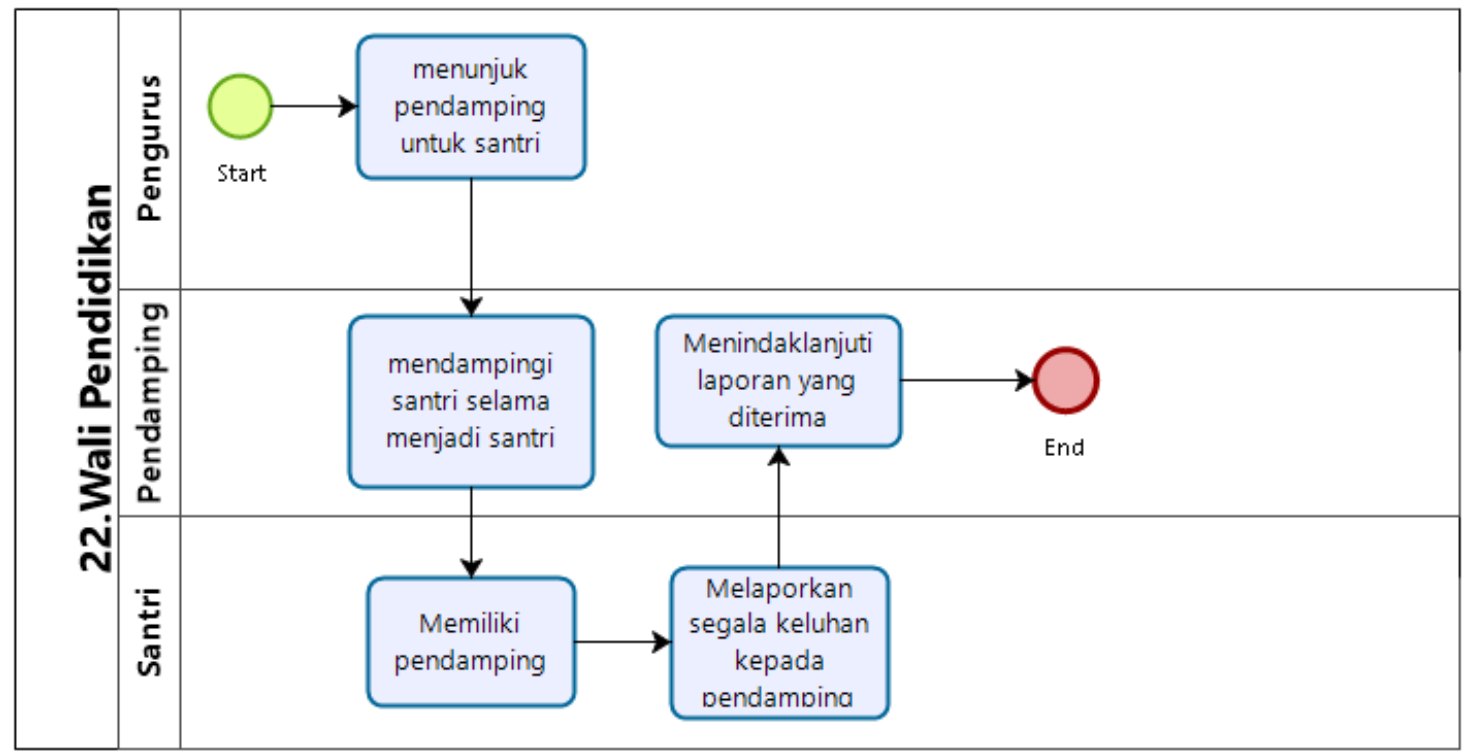

Gambar 23. Model proses bisnis standar wali Pendidikan

Gambar 23 menggambarkan prosedur tugas wali pendidikan. Pengurus menunjuk pendamping untuk santri selama menjadi santri. santri berhak melaporkan seluruh keluhan kepada pendamping. pendamping menjadi jembatan dalam menindaklanjuti keluhan santri.

\section{Pemantauan Catatan (Monitoring)}

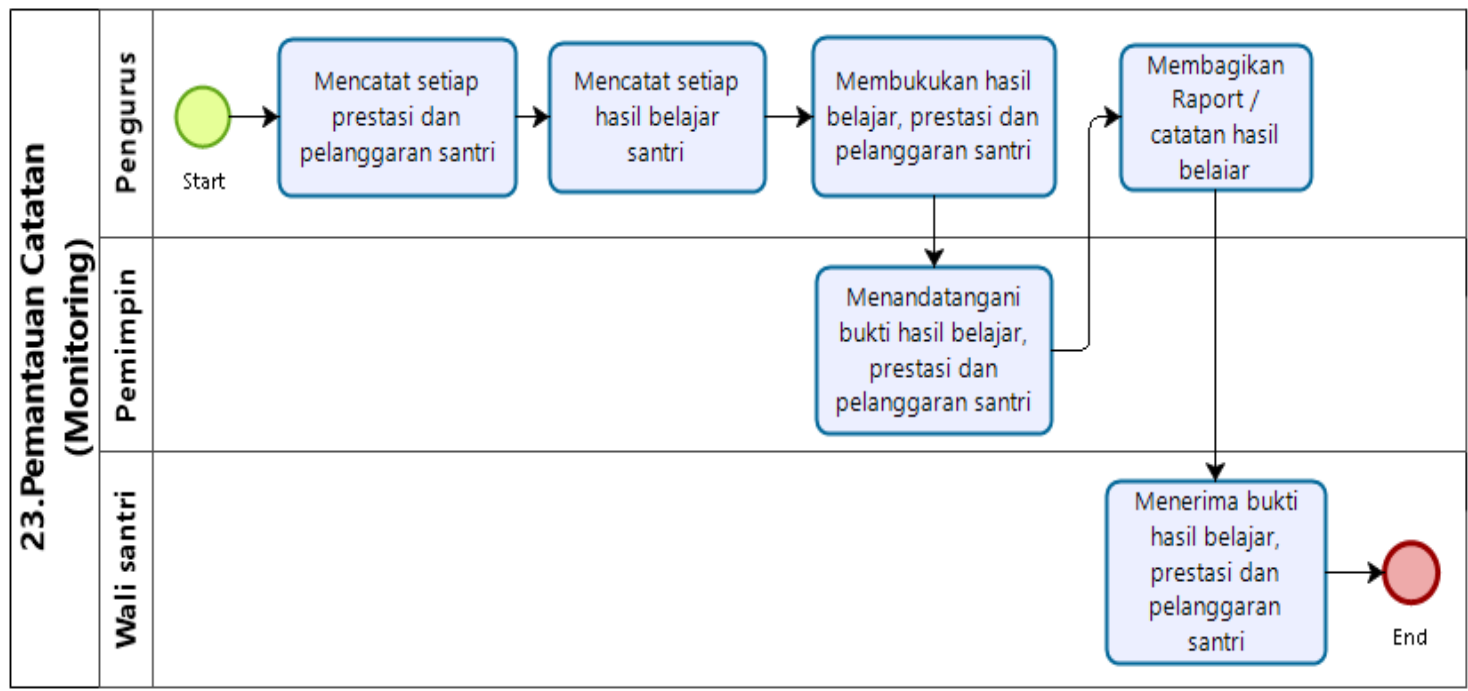

Gambar 24. Model proses bisnis standar monitoring

Gambar 24 menggambarkan prosedur pemantauan catatan. Pengurus mencatat prestasi dan pelanggaran santri serta hasil belajar santri. seluruh catatan dibukukan dan ditandatangani oleh pimpinan pesantren. pengurus membagikan catatan ke wali santri. 
24. Asrama menerima penyediaan makanan berkualitas baik

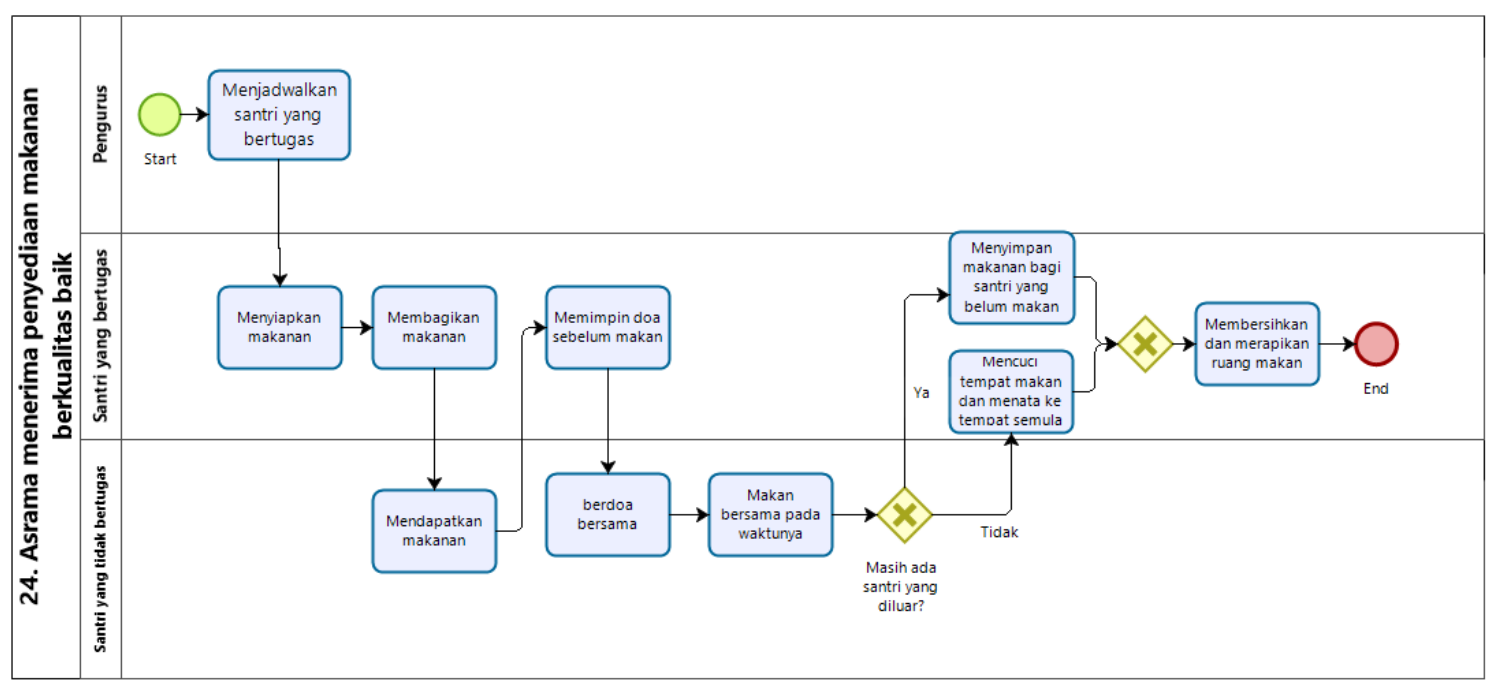

Gambar 25. Model proses bisnis standar penyediaan makanan berkualitas baik

Gambar 25 menggambarkan prosedur penyediaan makanan. Pengurus menjadwalkan santri yang menyediakan makanan. santri yang mendapatkan jadwal memasak menyiapkan dan membagikan makanan. sebelum dan sesudah makan santri berdoa terlebih dahulu. apabila masih ada santri yang berkegiatan di luar maka menyisakan makanan untuk santri tersebut. setelah selesai makan maka seluruh perlengkapan memasak dan makan harus dicuci.

25. Asrama Memiliki akses ke makanan dan air minum selain makanan utama

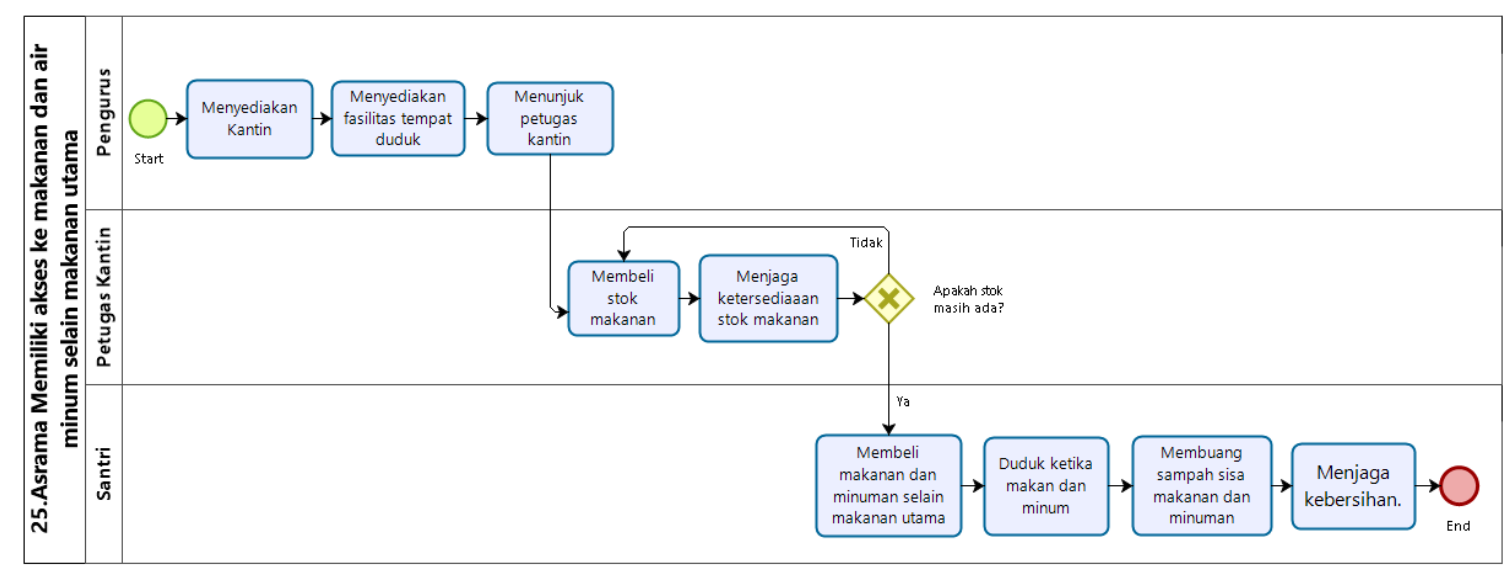

Gambar 26. Model Proses bisnis standar Asrama Memiliki akses ke makanan dan air minum selain makanan utama

Gambar 26 menggambarkan prosedur penyediaan kantin. Pengurus membentuk petugas kantin dan memfasilitasi seluruh kebutuhan kantin. petugas kantin selalu menjaga ketersediaan produk. santri dapat membeli makanan ringan dan minuman di kantin dan makan mengkonsumsinya di tempat yang telah disediakan dengan tetap menjaga kebersihan. 
26. Asrama dilindungi dari resiko kebakaran

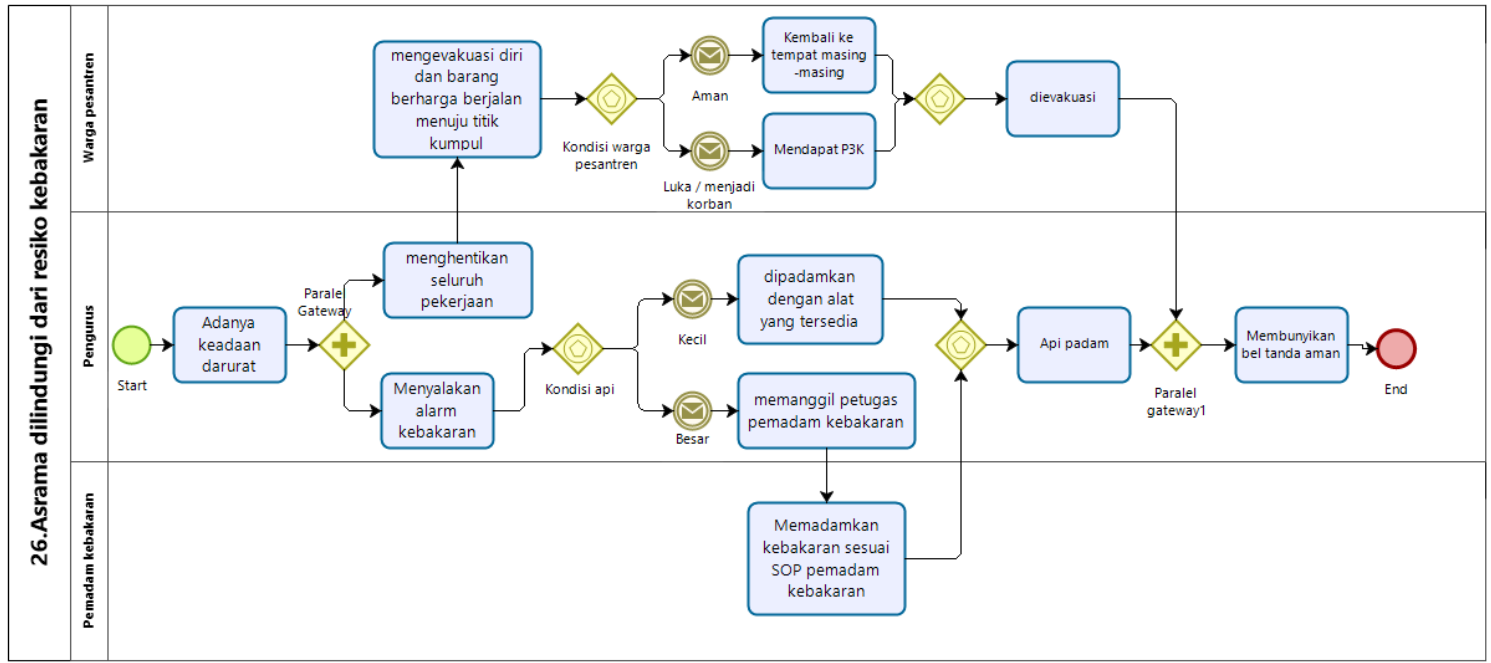

Gambar 27. Model Proses bisnis standar Asrama dilindungi dari resiko kebakaran

Gambar 27 menggambarkan prosedur penanganan keadaan darurat. ketika terjadi keadaan darurat kebakaran pengurus menyalakan alarm. seluruh warga pesantren menghentikan seluruh pekerjaannya dan mengevakuasi diri dan barang berharganya. Jika terjadi korban maka mendapatkan perawatan sebagaimana telah dijelaskan pada poin 15 . diwaktu bersamaan, apa bila kondisi api besar maka memanggil petugas pemadam kebakaran untuk memadaman api. jika api kecil maka dipadamkan dengan alat yang tersedia. ketika kondisi aman pengurus menyalakan alarm dan seluruh warga pesantren dapat kembali ke tempat masing-masing.

\section{Tuntutan yang membebani Santri}

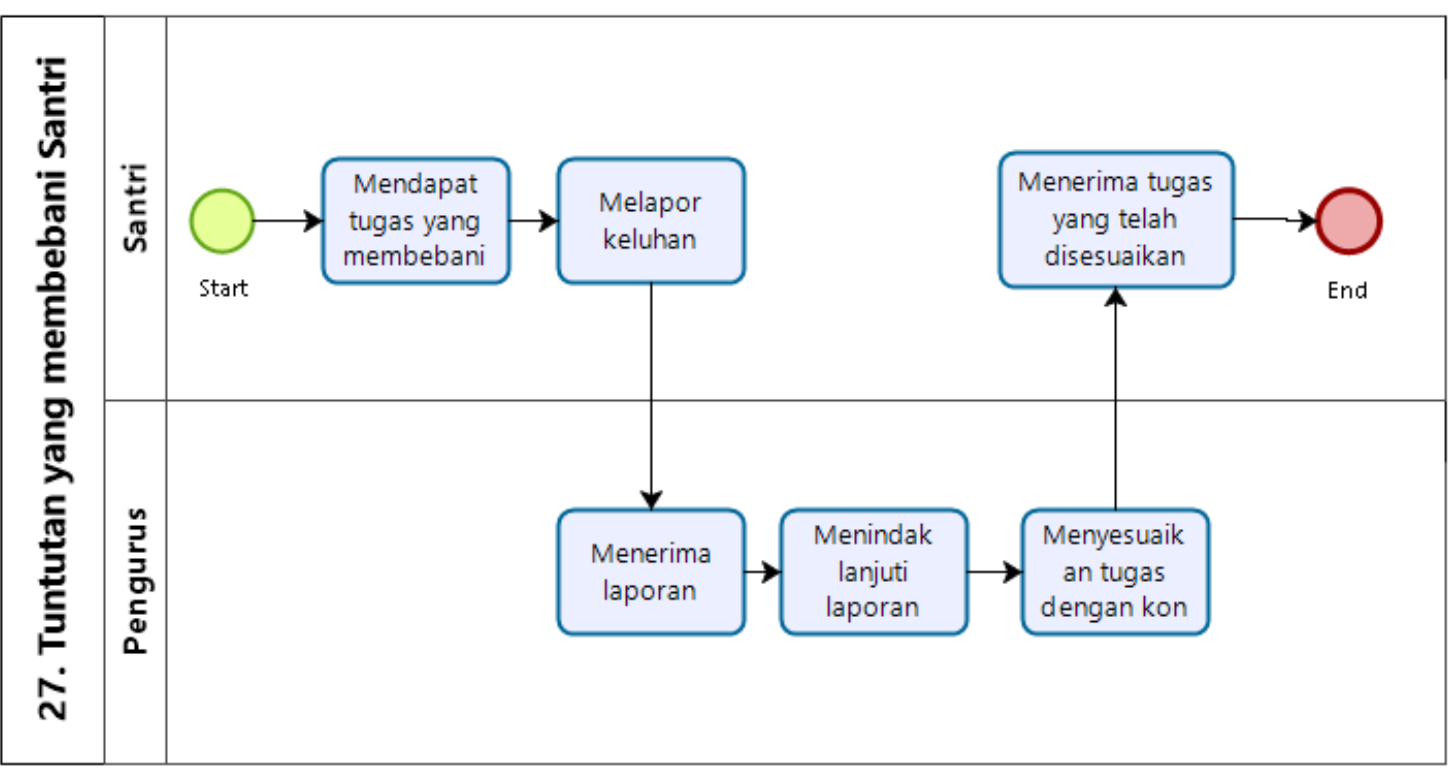

Gambar 28. Model Proses bisnis standar Tuntutan yang membebani Santri

Gambar 28 menggambarkan prosedur penanganan keadaan darurat. ketika terjadi keadaan darurat pengurus menyalakan alarm. seluruh warga pesantren menghentikan seluruh pekerjaannya dan mengevakuasi diri dan barang berharganya. Jika terjadi korban maka mendapatkan perawatan sebagaimana telah dijelaskan pada poin 15 ketika kondisi 
aman pengurus menyalakan alarm dan seluruh warga pesantren dapat kembali ke tempat masing-masing.

28. Akomodasi anak selain siswa

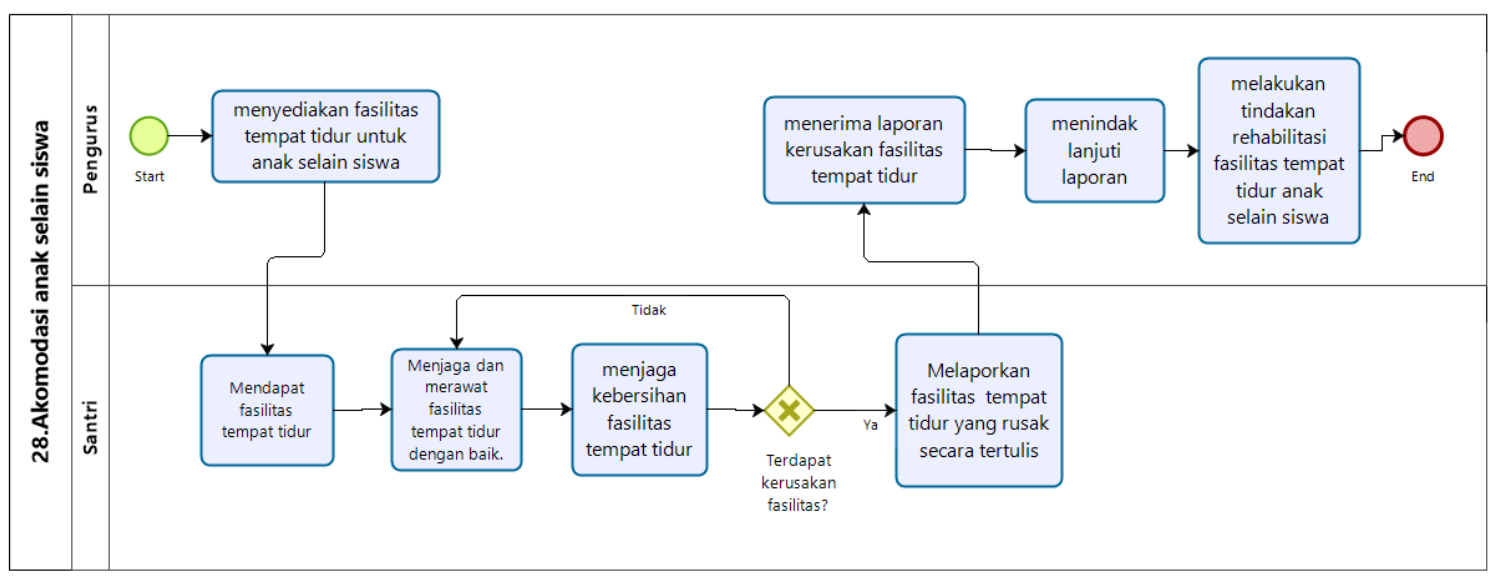

Gambar 29. Model Proses bisnis standar Akomodasi anak selain siswa

Gambar 29 menggambarkan prosedur penggunaan fasilitas tempat tidur untuk anak selain siswa. Dimulai dari Pengurus menyediakan tempat tidur untuk anak selain siswa. Santri wajib menjaga dan merawat fasilitas tempat tidur untuk anak selain siswa. Jika terdapat kerusakan fasilitas harus melapor secara tertulis ke pengurus yang nantinya akan menindak lanjuti laporan. Kemudian pengurus memvalidasi laporan. Pengurus segera melakukan tindakan rehabilitasi fasilitas.

29. Keselamatan dan kesejahteraan penghuni dilindungi selama aktivitas berisiko tinggi

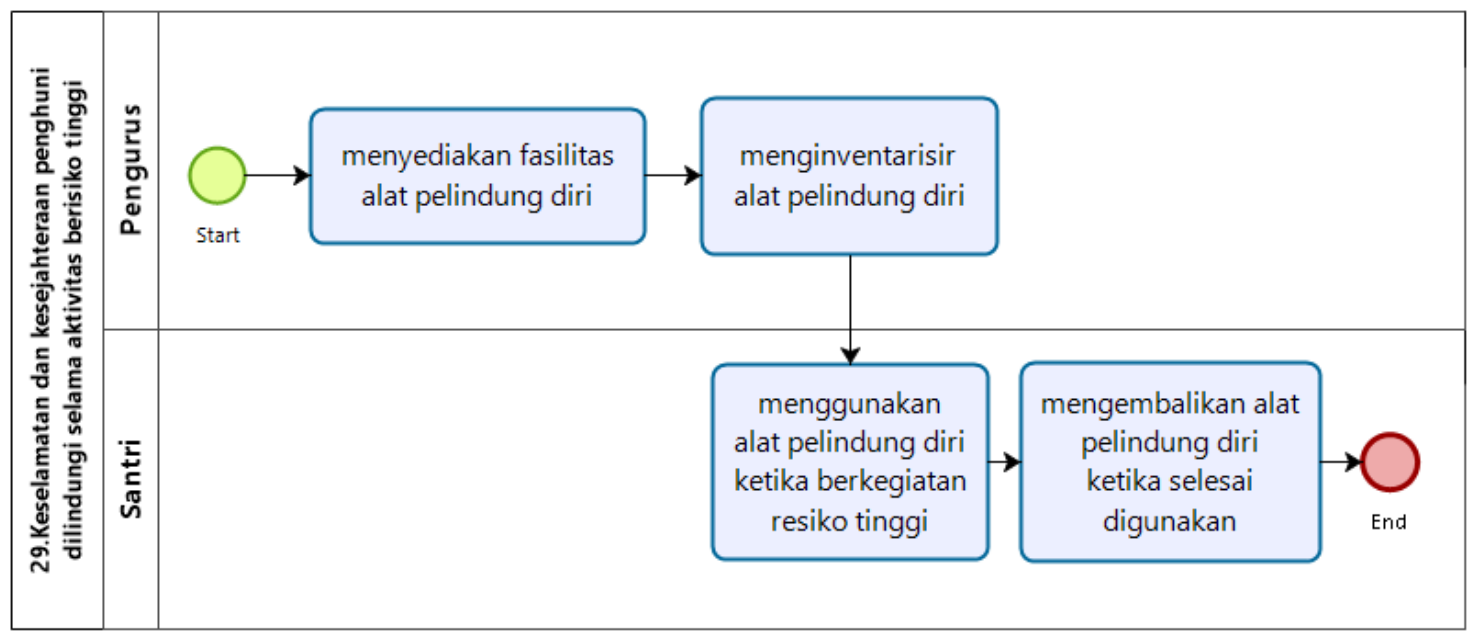

Gambar 30. Model Proses bisnis standar Keselamatan dan kesejahteraan penghuni dilindungi selama aktivitas berisiko tinggi

Gambar 30 menggambarkan prosedur meminimalisir resiko tinggi. Dimulai dari Pengurus menyediakan fasilitas alat pelindung diri. pengurus menginventarisir alat pelindung diri. ketika melakukan kegiatan beresiko tinggi satri wajib menggunakan alat pelindung diri. setelah alat pelindung diri selesai digunakan maka dikembalikan. 
30. Santri memiliki akses yang sesuai ke informasi dan fasilitas di luar sekolah

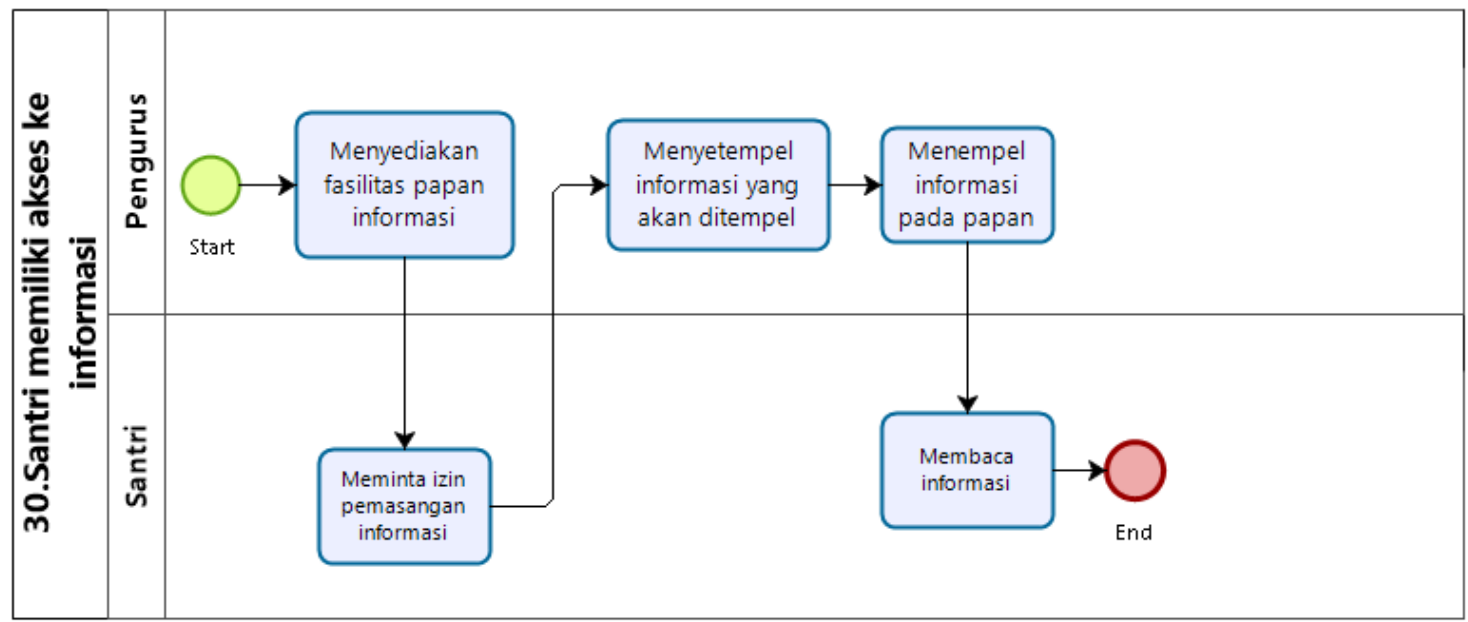

Gambar 31. Model Proses bisnis standar Santri memiliki akses yang sesuai ke informasi dan fasilitas di luar sekolah

Gambar 31 menggambarkan prosedur penggunaan fasilitas papan informasi. Santri yang akan mempublikasi informasi harus memohon izin ke pengurus yang dibuktikan dengan stempel. informasi yang valid akan dipublikasi oleh pengurus dengan cara ditempel pada papan informasi yang dapat dibaca setiap santri.

31. Santri diawasi secara memadai oleh staf

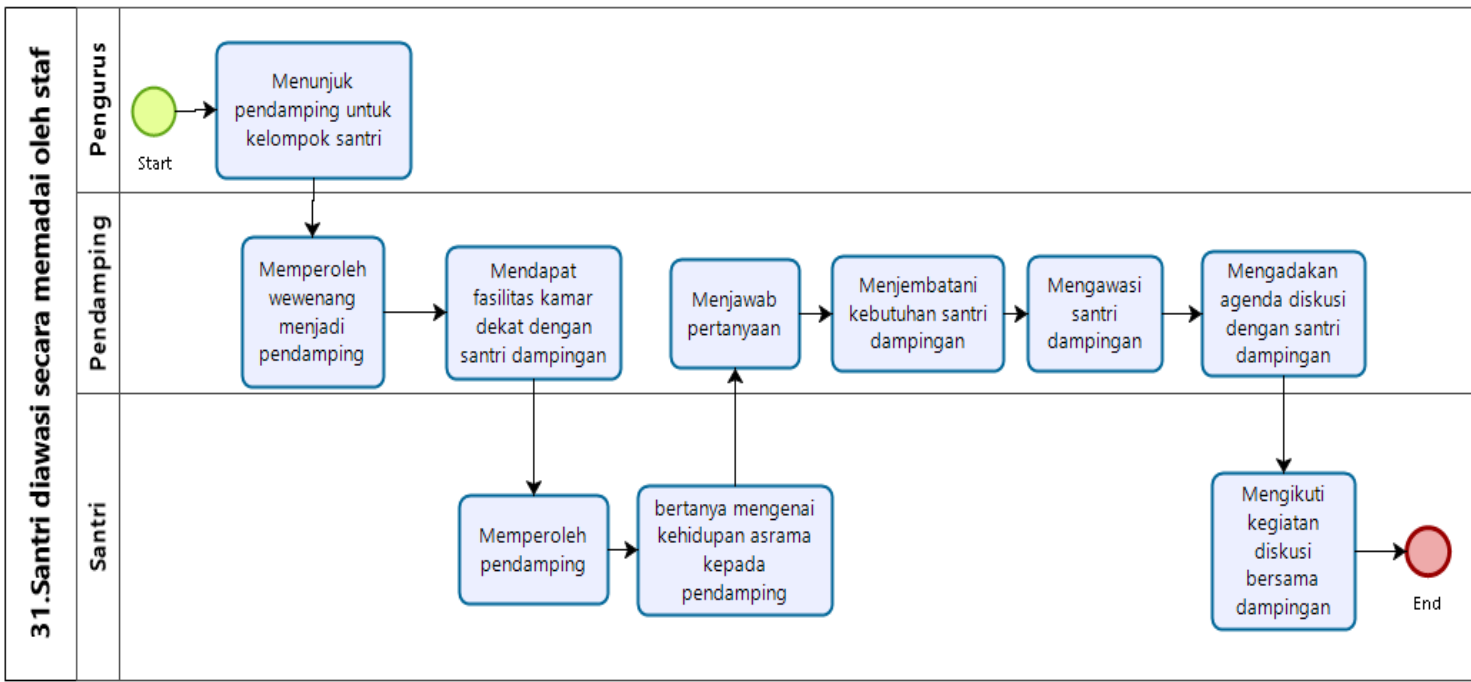

Gambar 32. Model Proses bisnis standar Santri diawasi secara memadai oleh staf

Gambar 32 menggambarkan prosedur pengawasan dan pendampingan santri. Pengurus menunjuk pendamping untuk mendampingi sekelompok santri. Pendamping mendapatkan fasilitas kamar dekat dengan santri dampingan. Santri berhak bertanya kepada pendamping. Selain itu pendamping juga berperan menjembatani kebutuhan santri dampingan serta mengawasi keseharian santri dan mengagendakan diskusi dengan santri. 
32. Pengawasan para penghuni asrama yang meninggalkan lokasi sekolah

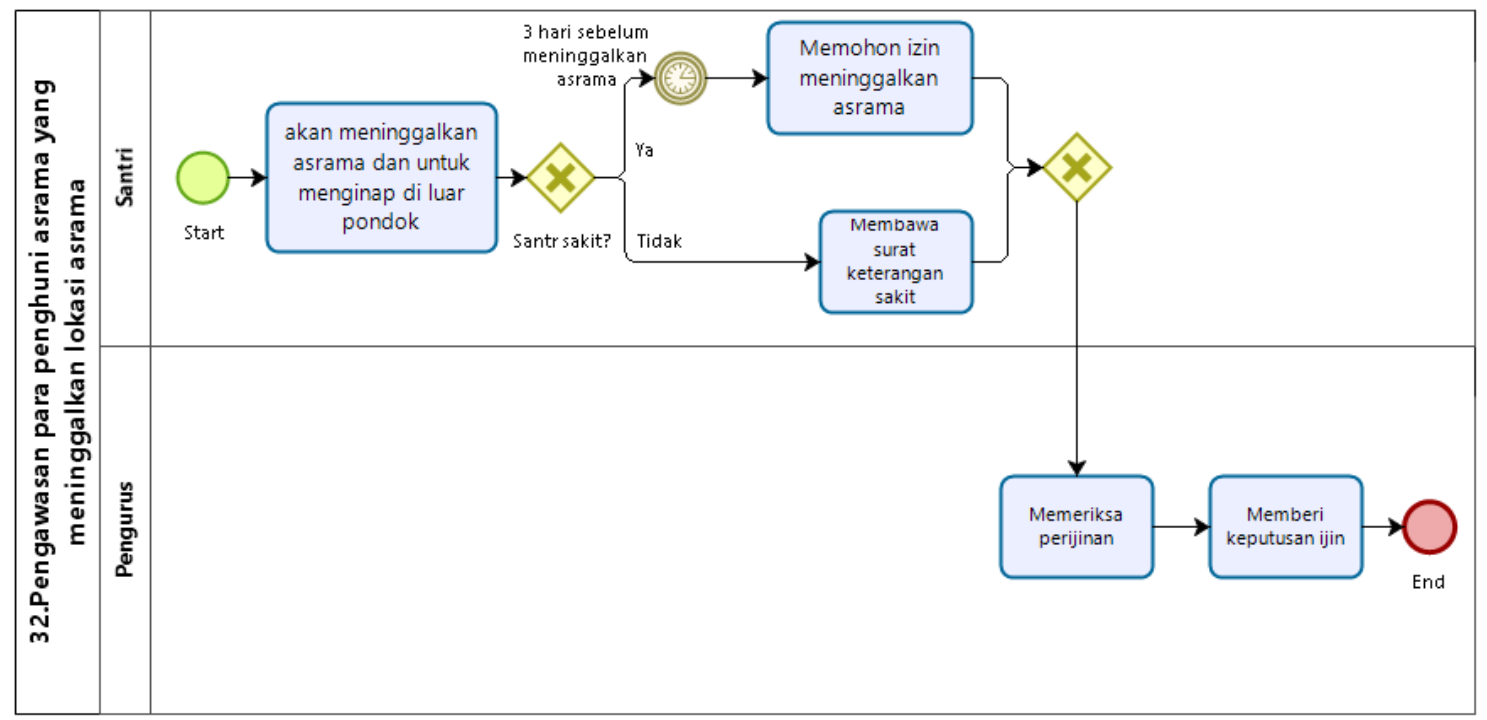

Gambar 33. Model Proses bisnis standar Pengawasan para penghuni asrama yang meninggalkan lokasi sekolah

Gambar 34 menggambarkan prosedur pengawasan para penghuni asrama yang meninggalkan lokasi asrama. santri yang akan meninggalkan asrama dan menginap di luar pondok diwajibkan untuk memohon izin setidaknya 3 hari sebelum meninggalkan asrama kecuali santri yang sakit dapat mendapatkan izin dengan surat keterangan sakit. Pengurus memeriksa perizinan dan memberi keputusan izin.

33. Pengawasan malam para penghuni asrama

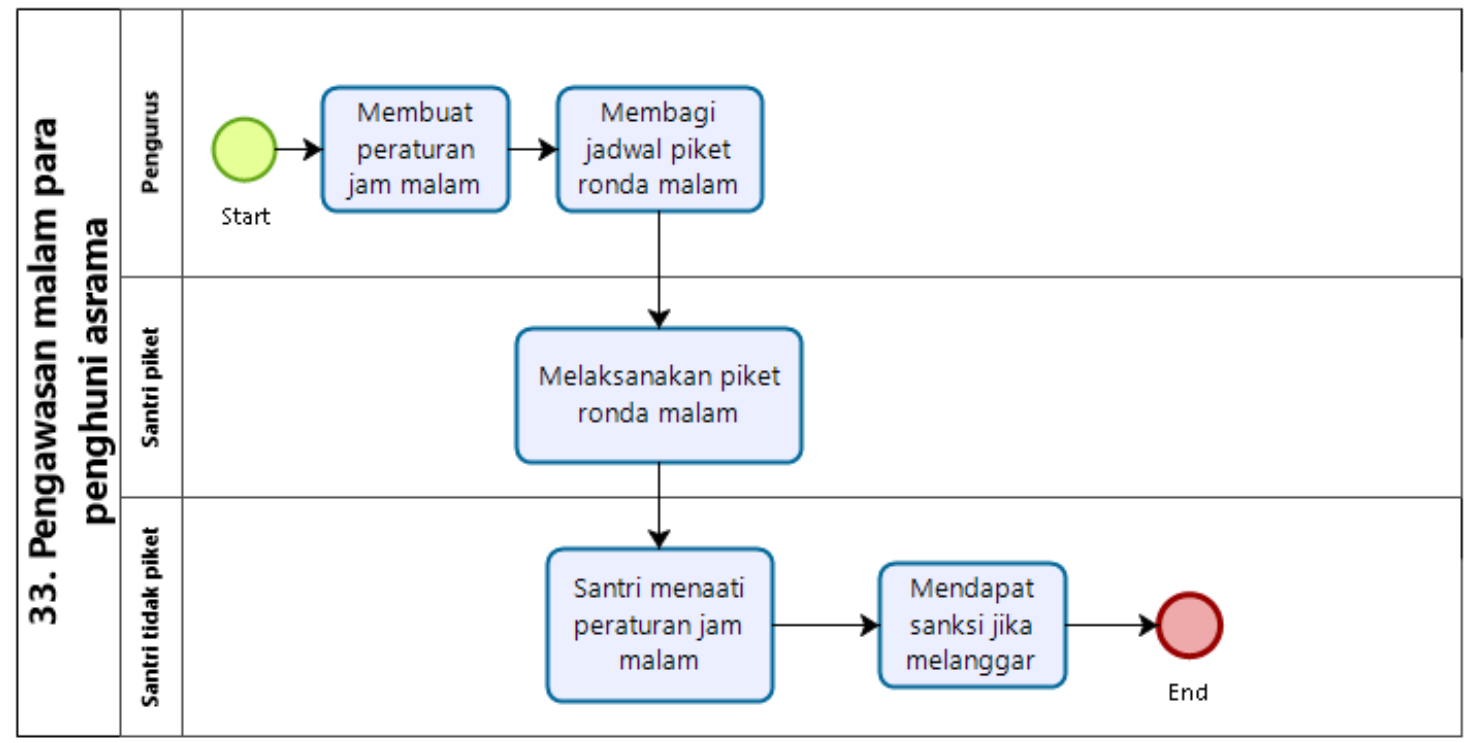

Gambar 34. Model Proses bisnis standar Pengawasan malam para penghuni asrama

Gambar 34 menggambarkan prosedur pengawasan malam para penghuni asrama. Pengurus membuat aturan jam malam serta membagi jadwal piket ronda malam. santri yang mendapat jadwal ronda malam melakukan piket ronda malam. Apabila ada santri yang melanggar jam malam maka mendapat sanksi. 
34. Deskripsi pekerjaan staf, induksi, supervisi, pelatihan

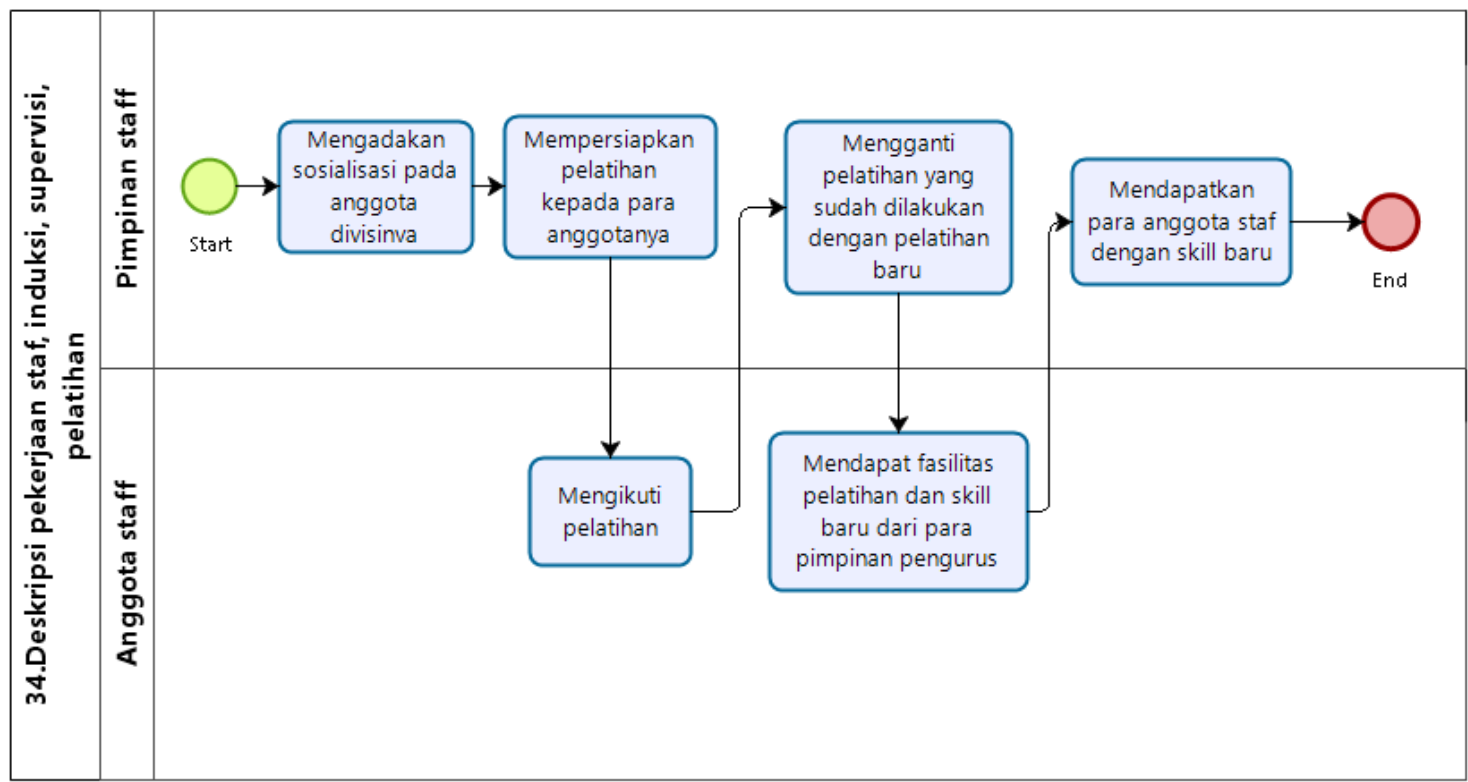

Gambar 35. Model Proses bisnis standar Deskripsi pekerjaan staf, induksi, supervisi, pelatihan

Gambar 35 menggambarkan prosedur peningkatan kemampuan pengurus. pimpinan staf mengadakan sosialisasi pada anggota divisinya dan mempersiapkan pelatihan kepada anggotanya. seluruh staff wajib mengikuti pelatihan yang diadakan.

35. Pedoman pelaksanaan praktik staf

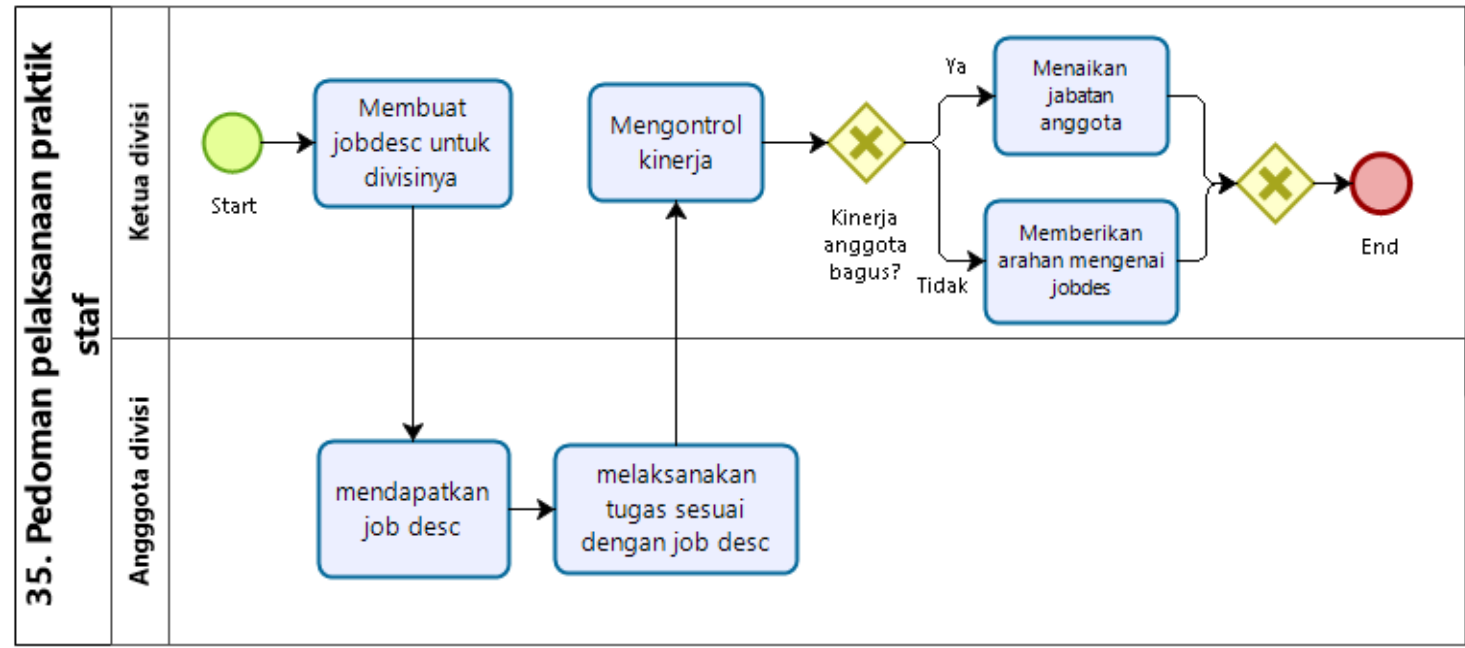

Gambar 36. Model Proses bisnis standar Pedoman pelaksanaan praktik staf

Gambar 36 diatas menggambarkan prosedur pelaksanaan praktik staf. ketua divisi membuat jobdesc untuk anggotanya. anggota melaksanakan tugas sesuai job desk nya. ketua divisi mengontrol kinerja anggota. apabila kinerja anggota bagus maka akan menaikan jabatan anggota, apabila kurang bagus akan memberikan arahan. 
36. Ada hubungan yang baik antara staf dan penghuni asrama

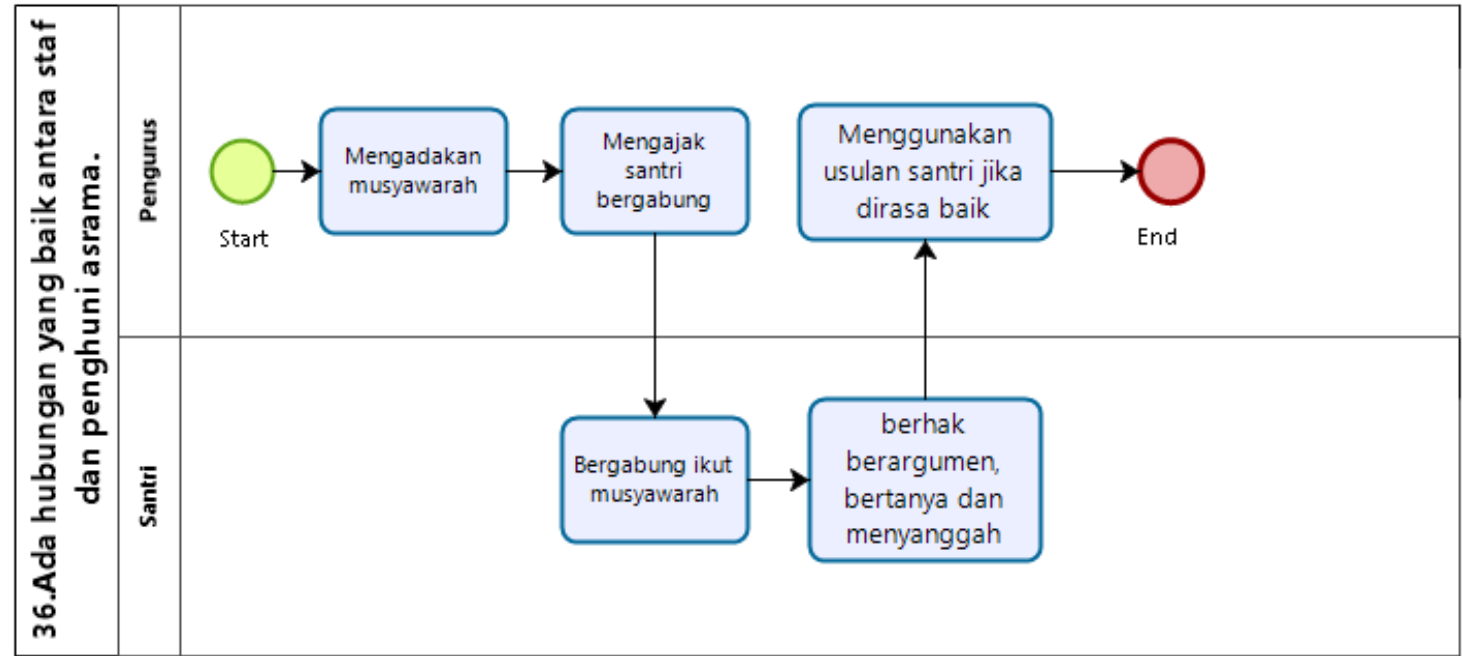

Gambar 37. Model Proses bisnis standar Ada hubungan yang baik antara staf dan penghuni asrama

Gambar 37 menggambarkan prosedur hubungan antara santri dengan pengurus. pengurus mengadakan musyawarah dengan selalu mengajak santri turut serta dalam musyawarah. santri juga berhak berargumen dalam musyawarah.

37. Privasi pribadi penghuni dihormati

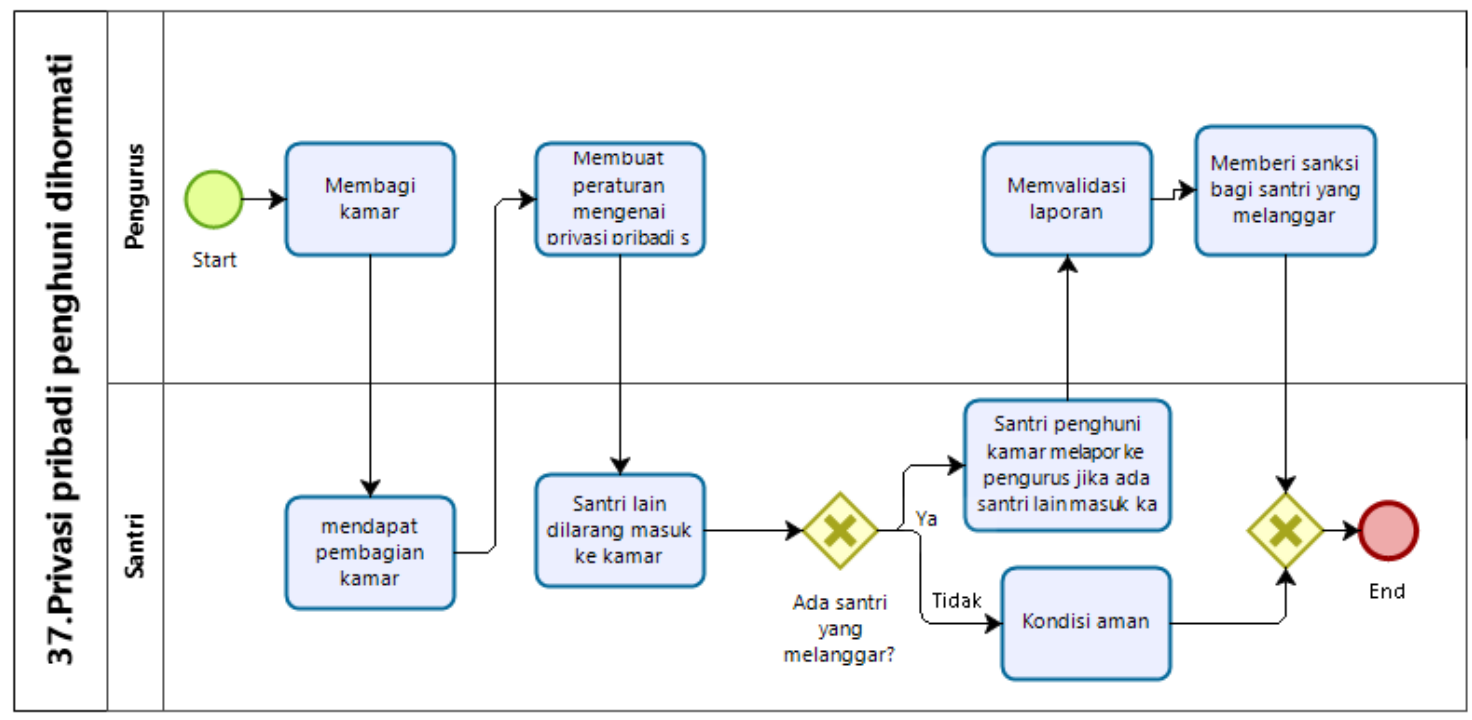

Gambar 38. Model Proses bisnis standar Privasi pribadi penghuni dihormati

Gambar 38 menggambarkan prosedur menghormati privasi penghuni. Pegurus membagi kamar sesuai dengan kapasitas dan membuat peraturan mengenai privasi kamar. santri lain dilarang masuk ke kamar. apabila ada santri yang melanggar maka santri penghuni kamar dapat melaporkan ke pengurus. pengurus memvalidasi laporan serta memberi sanksi bagi santri yang melanggar. 
38. Ada seleksi ketat dan pemeriksaan semua staf dan relawan yang bekerja dengannya asrama

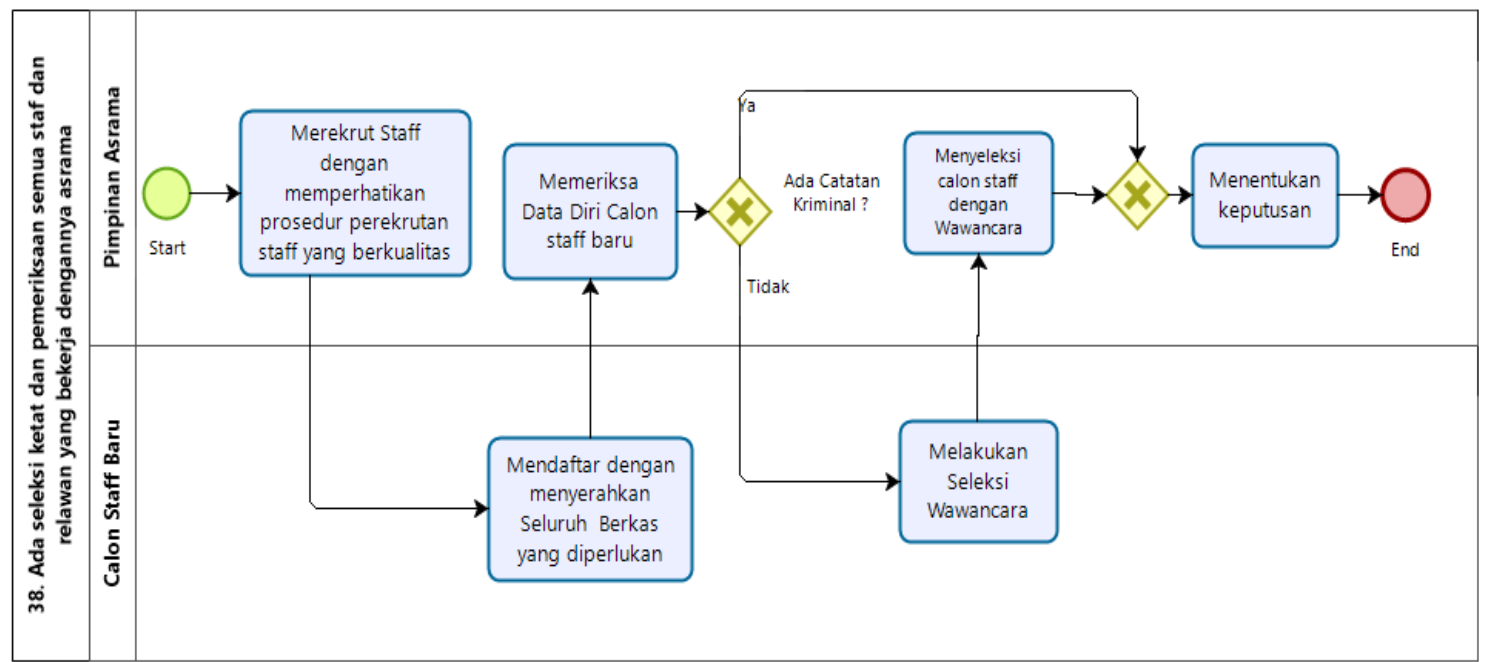

Gambar 39. Model Proses bisnis standar Ada seleksi ketat dan pemeriksaan semua staf dan relawan yang bekerja dengannya asrama

Gambar 39 menggambarkan prosedur seleksi staf. pimpinan asrama merekrut staf dengan memperhatikan prosedur perekrutan staff yang berkualitas. calon staff wajib menyerahkan seluruh berkas pendaftaran. pimpinan asrama memeriksa data diri calon staf baru. apabila ada catatan kriminal maka calon staf ditolak pendaftarannya. apabila tidak ada catatan kriminal staf melanjutkan seleksi wawancara. jika calon staff diterima maka calon staf menjadi staf.

39. Akses orang dewasa ke asrama dan akomodasi

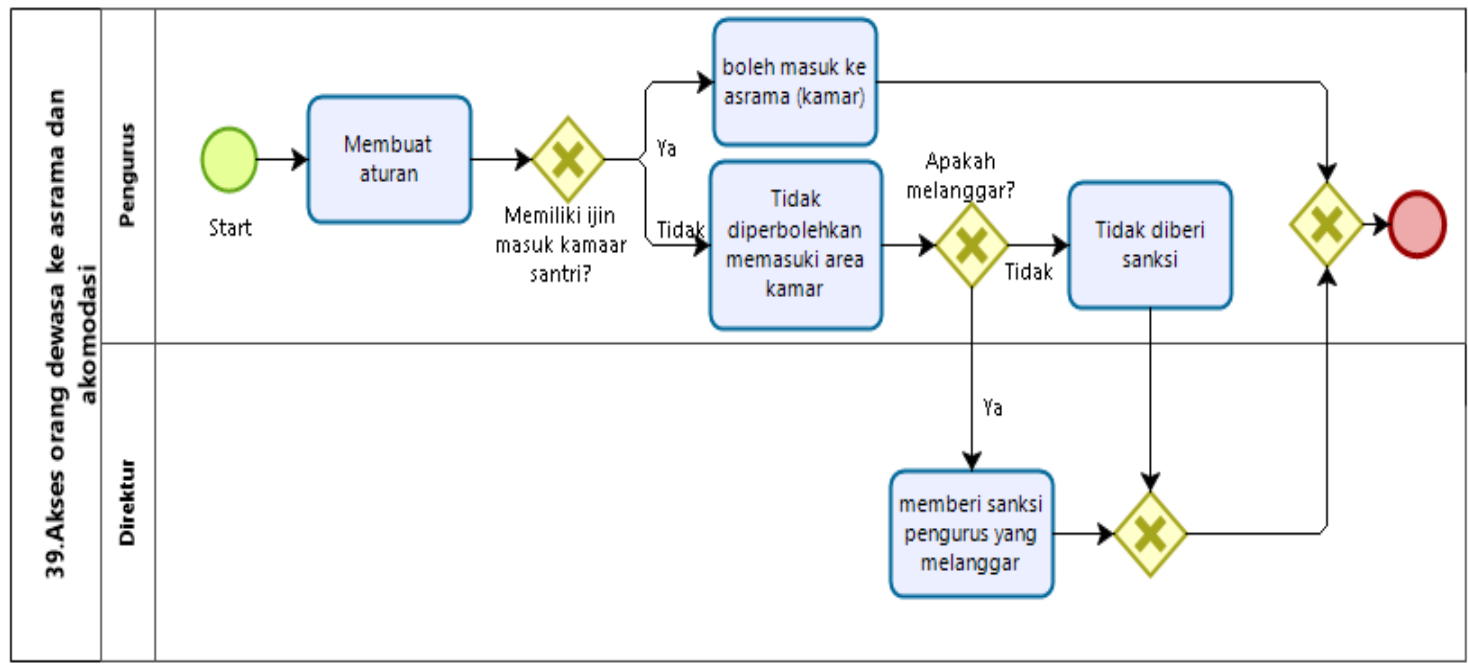

Gambar 40. Model Proses bisnis standar Akses orang dewasa ke asrama dan akomodasi

Gambar 40 menggambarkan prosedur akses orang dewasa ke asrama dan akomodasi. pengurus membuat aturan jika pengurus memiliki ijin asuk kamar santri maka boleh masuk kamar santri, apabila tidak diperbolehkan maka pengurus jika memasuki kamar maka melanggar peraturan dan diberi sanksi oleh direktur. 
40. Akomodasi asrama

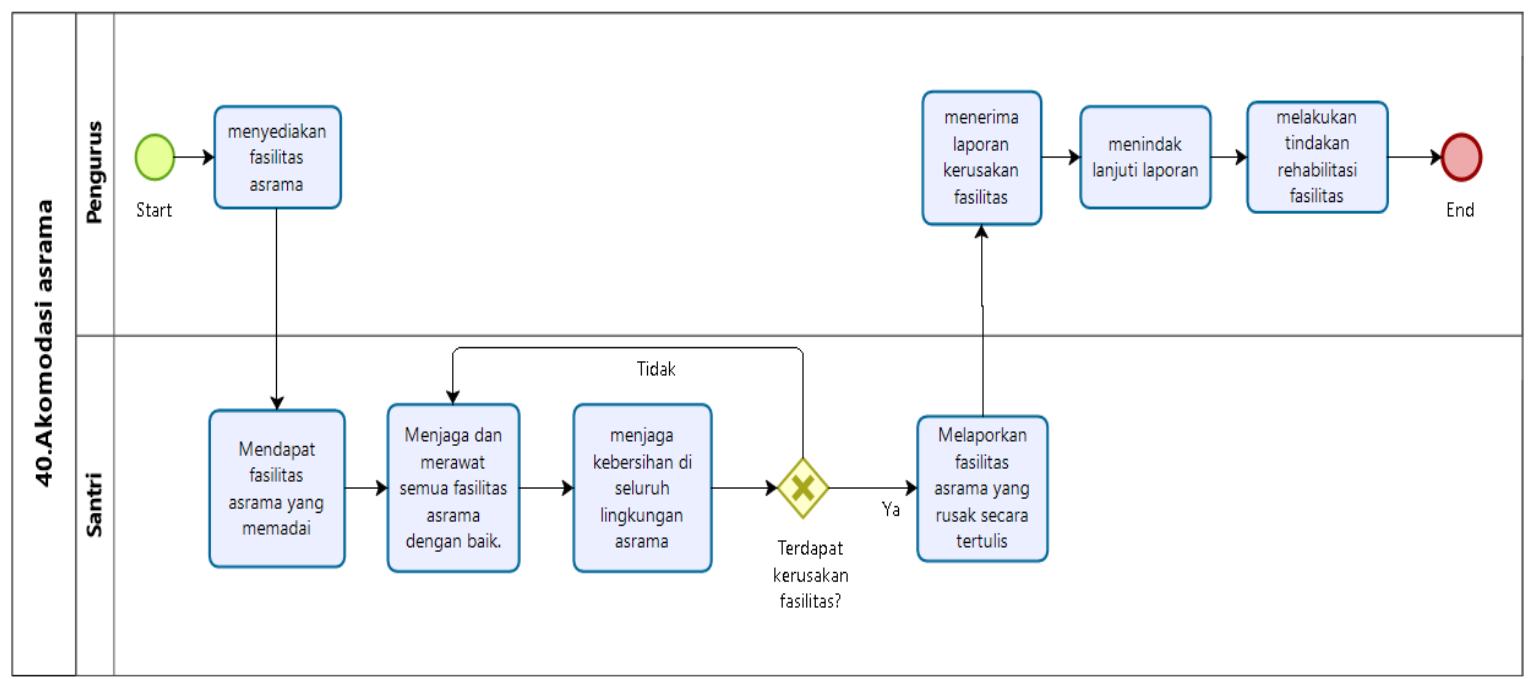

Gambar 41. Model Proses bisnis standar Akomodasi asrama

Gambar 41 menggambarkan prosedur penggunaan akomodasi asrama. Dimulai dari Pengurus menyediakan akomodasi asrama. Santri wajib menjaga dan merawat fasilitas akomodasi asrama. Jika terdapat kerusakan fasilitas harus melapor secara tertulis ke pengurus yang nantinya akan menindak lanjuti laporan. Kemudian pengurus memvalidasi laporan. Pengurus segera melakukan tindakan rehabilitasi fasilitas.

\section{Akses dan keamanan pada akomodasi}

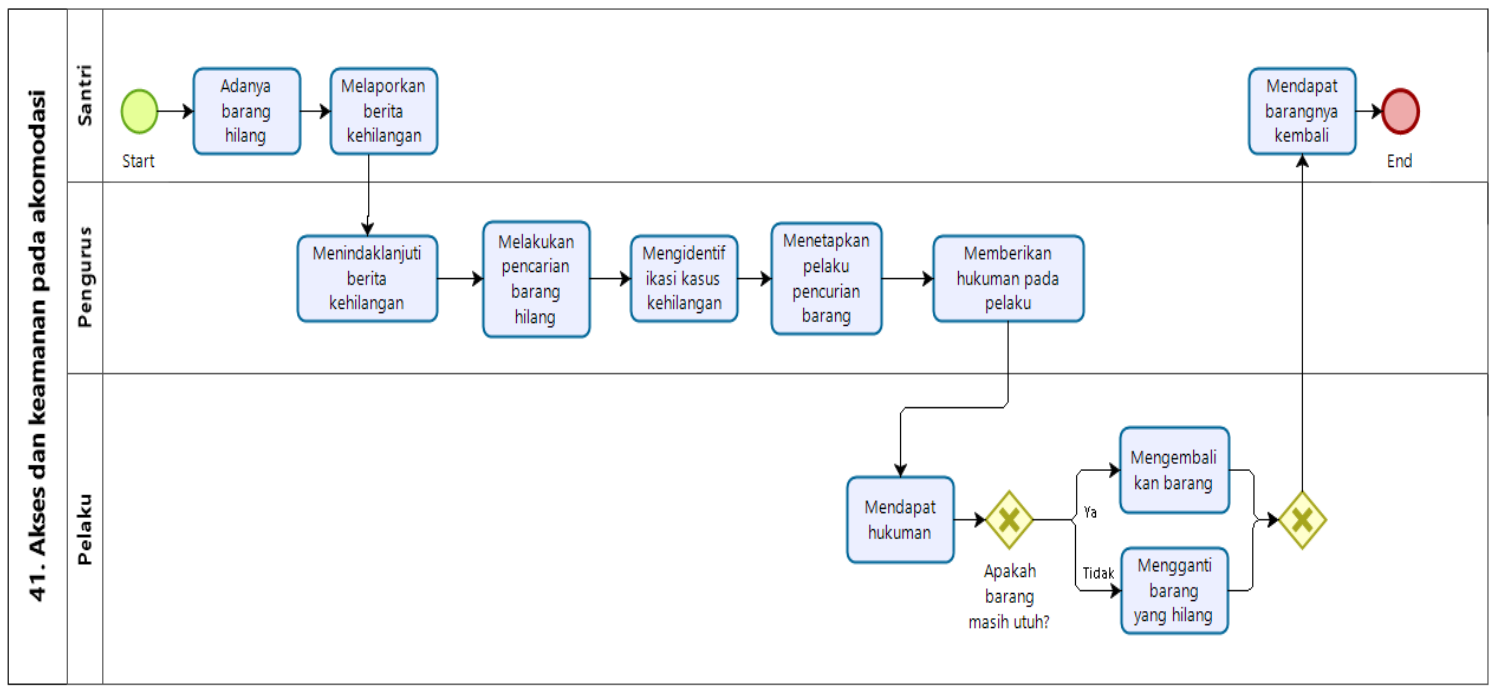

Gambar 42. Model Proses bisnis standar Akses dan keamanan pada akomodasi

Gambar 42 menggambarkan prosedur tindakan menjaga keamanan. Dimulai dari santri kehilangan barang sebagai keadaan awal, Santri yang menjadi korban harus melapor ke pengurus yang nantinya akan menindak lanjuti laporan. Pelaku yang telah disebutkan dan terbukti akan diberi sanksi dan wajib mengembalikan barang jika masih utuh, jika barang sudah tidak ada atau tidak utuh maka harus menggantinya. 


\section{Akomodasi tempat tidur}

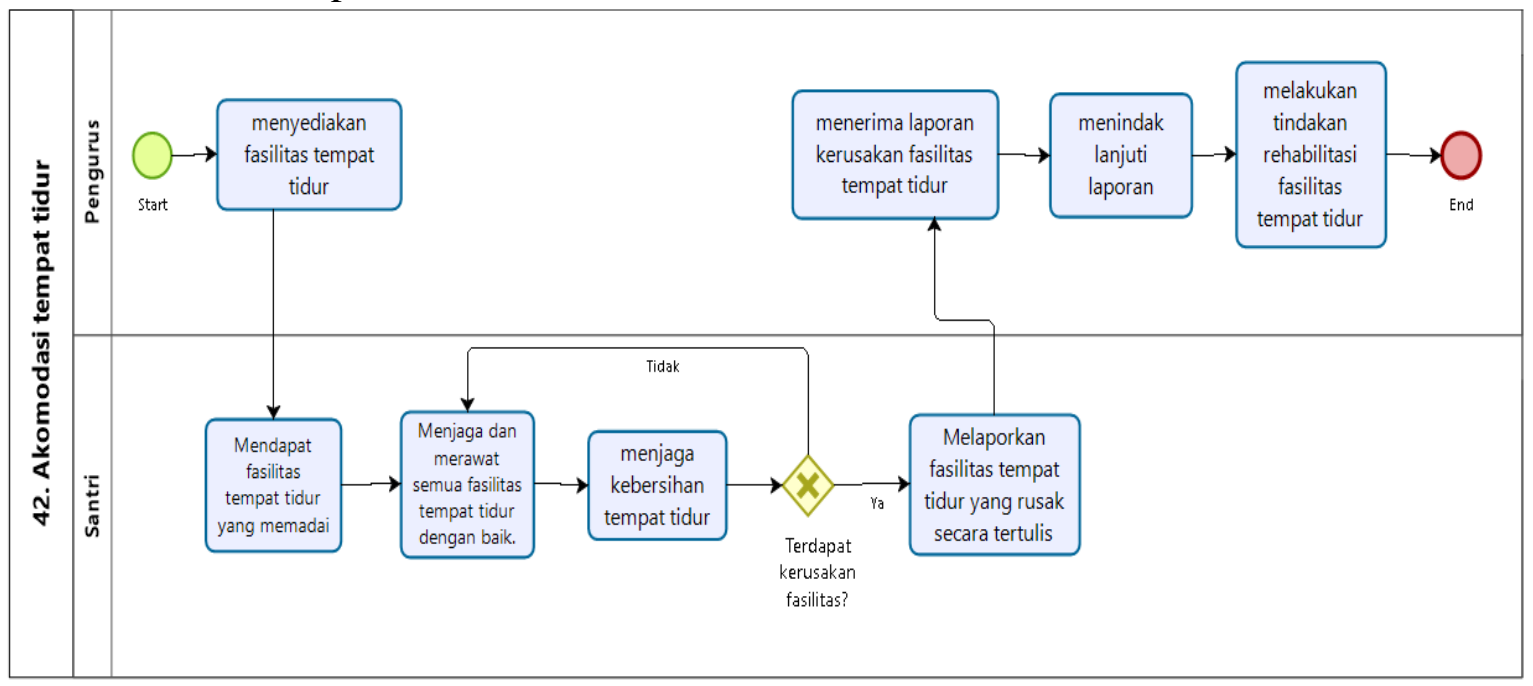

Gambar 43. Model Proses bisnis standar Akomodasi tempat tidur

Gambar 43 menggambarkan prosedur penggunaan akomodasi tempat tidur. Dimulai dari Pengurus menyediakan akomodasi tempat tidur. Santri wajib menjaga dan merawat fasilitas tempat tidur. Jika terdapat kerusakan fasilitas harus melapor secara tertulis ke pengurus yang nantinya akan menindak lanjuti laporan. Kemudian pengurus memvalidasi laporan. Pengurus segera melakukan tindakan rehabilitasi fasilitas.

\section{Aturan Pembelajaran}

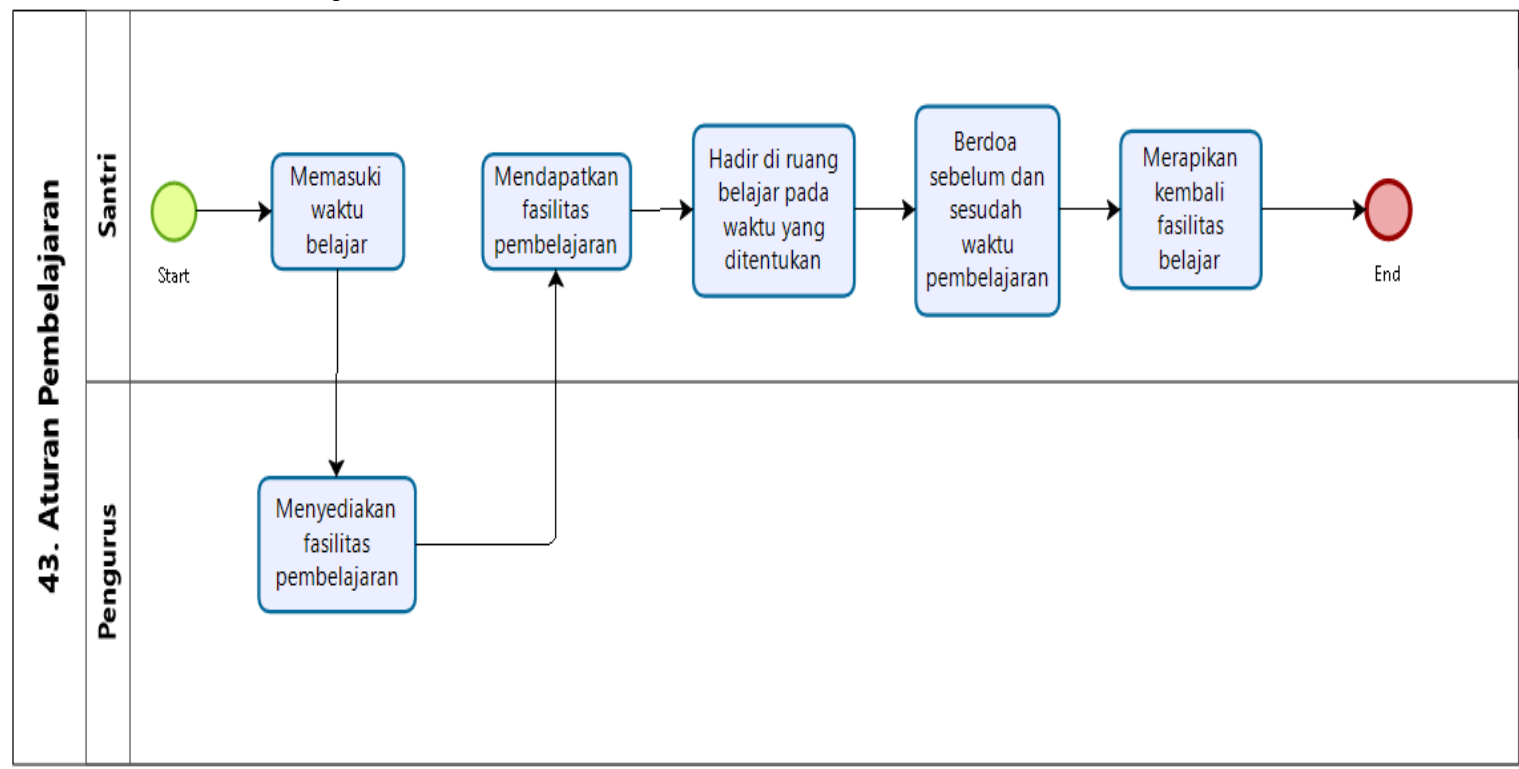

Gambar 44. Model Proses bisnis standar Aturan Pembelajaran

Gambar 44 menggambarkan prosedur jam belajar santri. Ketika telah memasuki waktu untuk santri belajar. Santri wajib hadir pada waktu yang ditentukan dan berdoa sebelum dan sesudah melakukan pembelajaran dan merapikan fasilitas belajar yang telah disediakan pengurus sebelumnya. 
44. Perlengkapan toilet dan mencuci

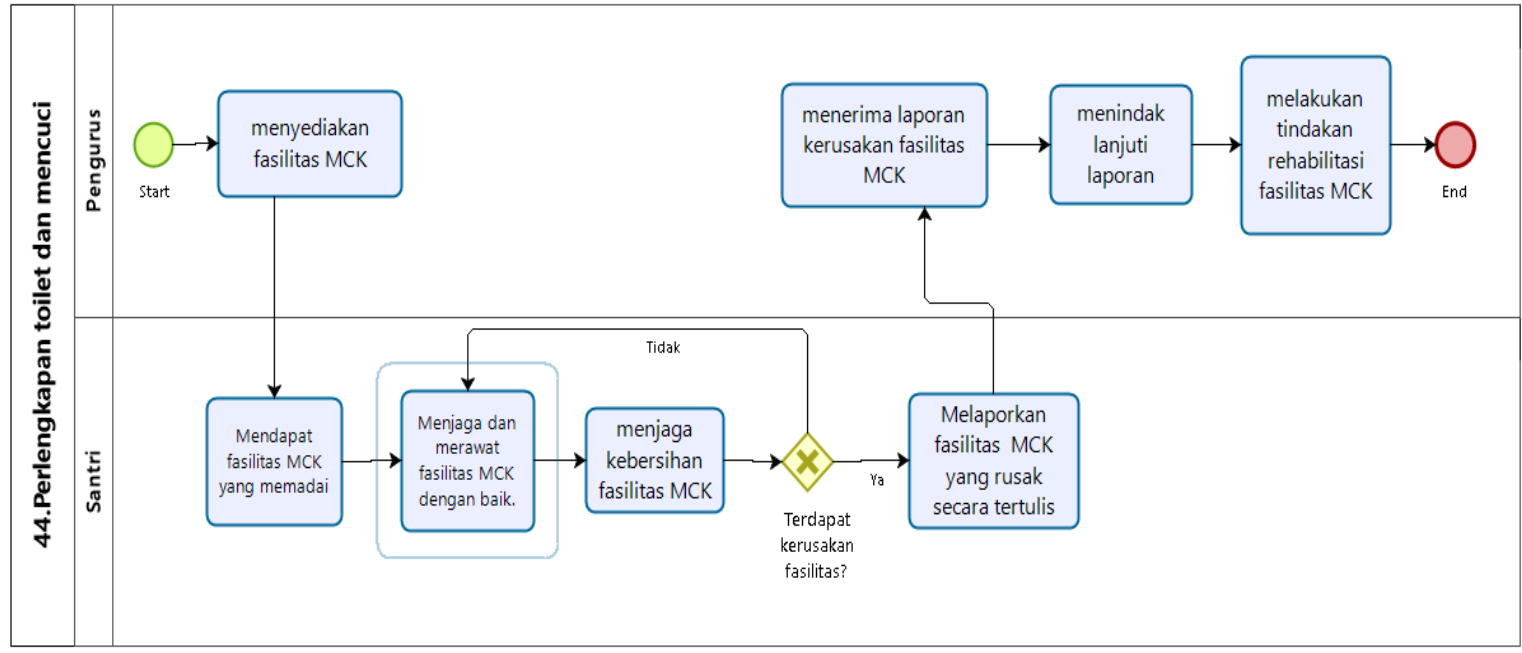

Gambar 45. Model Proses bisnis standar Perlengkapan toilet dan mencuci

Gambar 45 menggambarkan prosedur penggunaan MCK. Dimulai dari Pengurus menyediakan MCK. Santri wajib menjaga dan merawat fasilitas MCK. Jika terdapat kerusakan fasilitas harus melapor secara tertulis ke pengurus yang nantinya akan menindak lanjuti laporan. Kemudian pengurus memvalidasi laporan. Pengurus segera melakukan tindakan rehabilitasi fasilitas.

45. Fasilitas ruang ganti

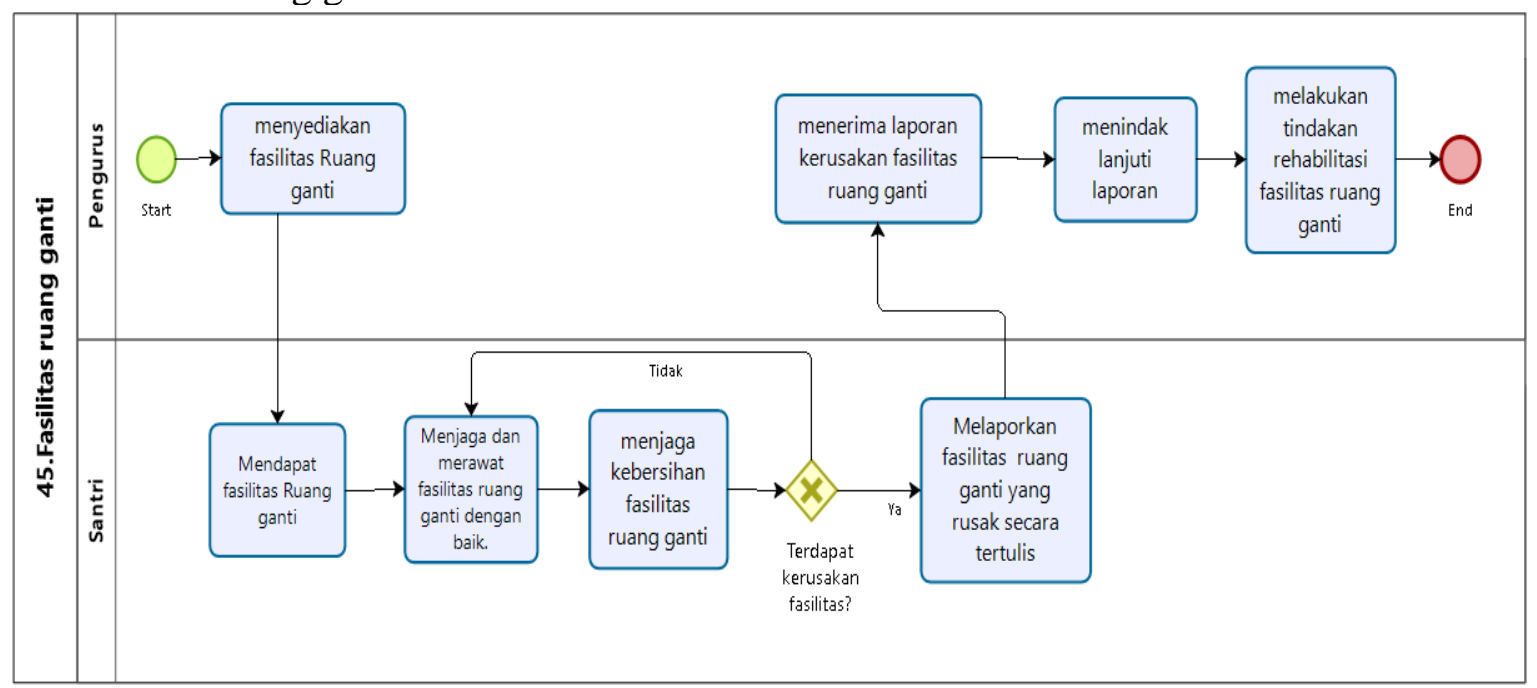

Gambar 46. Model Proses bisnis standar Fasilitas ruang ganti

Gambar 46 menggambarkan prosedur penggunaan ruang ganti santri. Dimulai dari Pengurus menyediakan ruang ganti santri. Santri wajib menjaga dan merawat fasilitas ruang ganti santri. Jika terdapat kerusakan fasilitas harus melapor secara tertulis ke pengurus yang nantinya akan menindak lanjuti laporan. Kemudian pengurus memvalidasi laporan. Pengurus segera melakukan tindakan rehabilitasi fasilitas. 
46. Tempat rekreasi

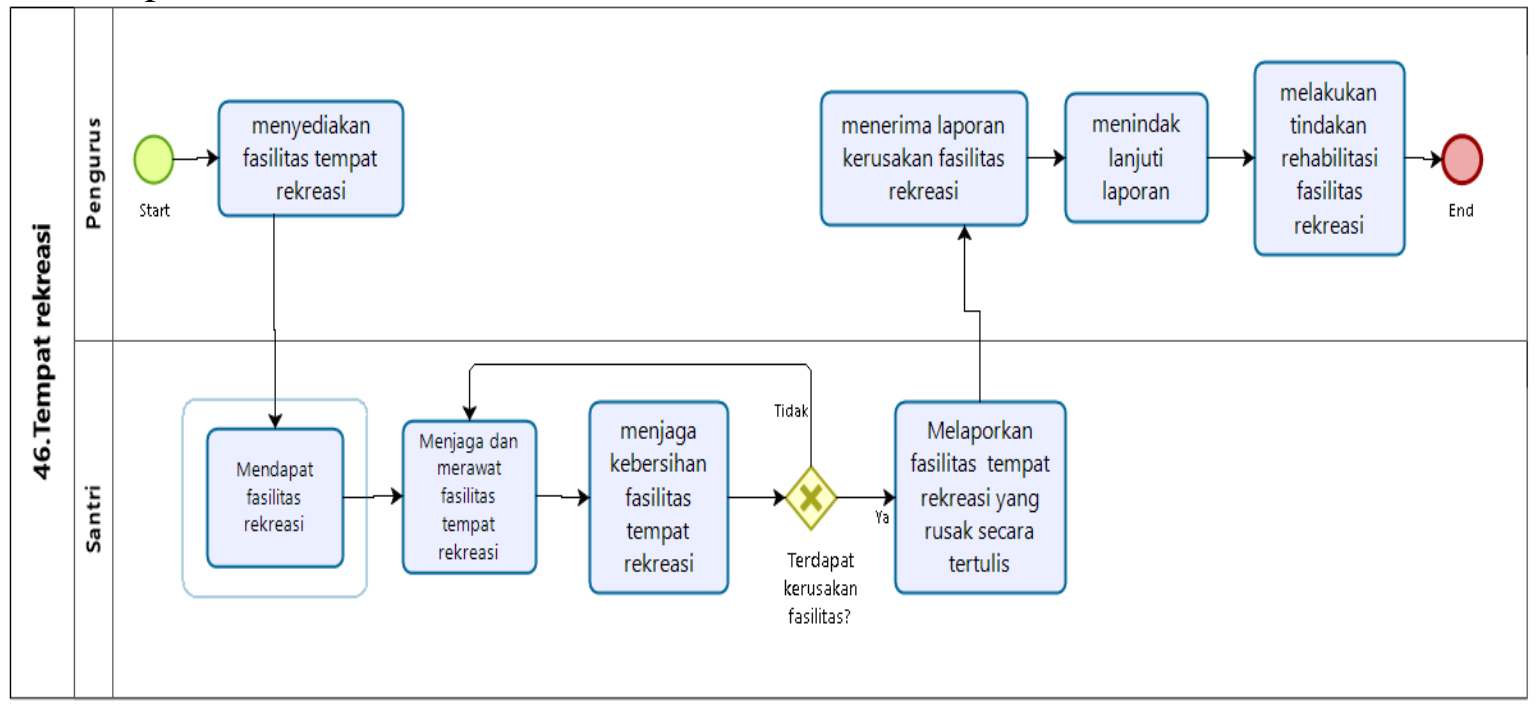

Gambar 47. Model Proses bisnis standar Tempat rekreasi

Gambar 47 menggambarkan prosedur penggunaan wilayah rekreasi pesantren. Dimulai dari Pengurus menyediakan wilayah rekreasi pesantren. Santri wajib menjaga dan merawat fasilitas wilayah rekreasi pesantren. jika terdapat kerusakan fasilitas harus melapor secara tertulis ke pengurus yang nantinya akan menindak lanjuti laporan. Kemudian pengurus memvalidasi laporan. Pengurus segera melakukan tindakan rehabilitasi fasilitas.

\section{Bahaya keselamatan dan penilaian risiko}

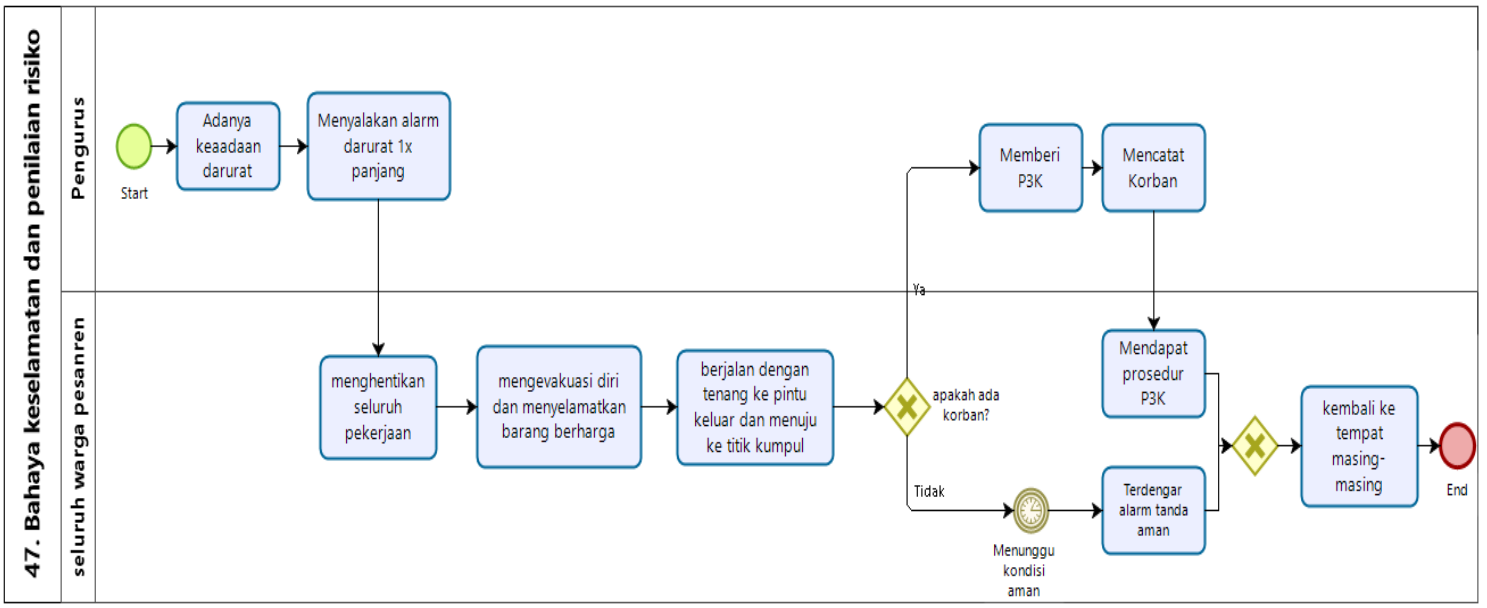

Gambar 48. Model Proses bisnis standar Bahaya keselamatan dan penilaian risiko

Gambar 48 menggambarkan prosedur penanganan keadaan darurat. ketika terjadi keadaan darurat pengurus menyalakan alarm. seluruh warga pesantren menghentikan seluruh pekerjaannya dan mengevakuasi diri dan barang berharganya. Jika terjadi korban maka mendapatkan perawatan sebagaimana telah dijelaskan pada poin 15 ketika kondisi aman pengurus menyalakan alarm dan seluruh warga pesantren dapat kembali ke tempat masing-masing. 
48. Akomodasi untuk murid yang sakit

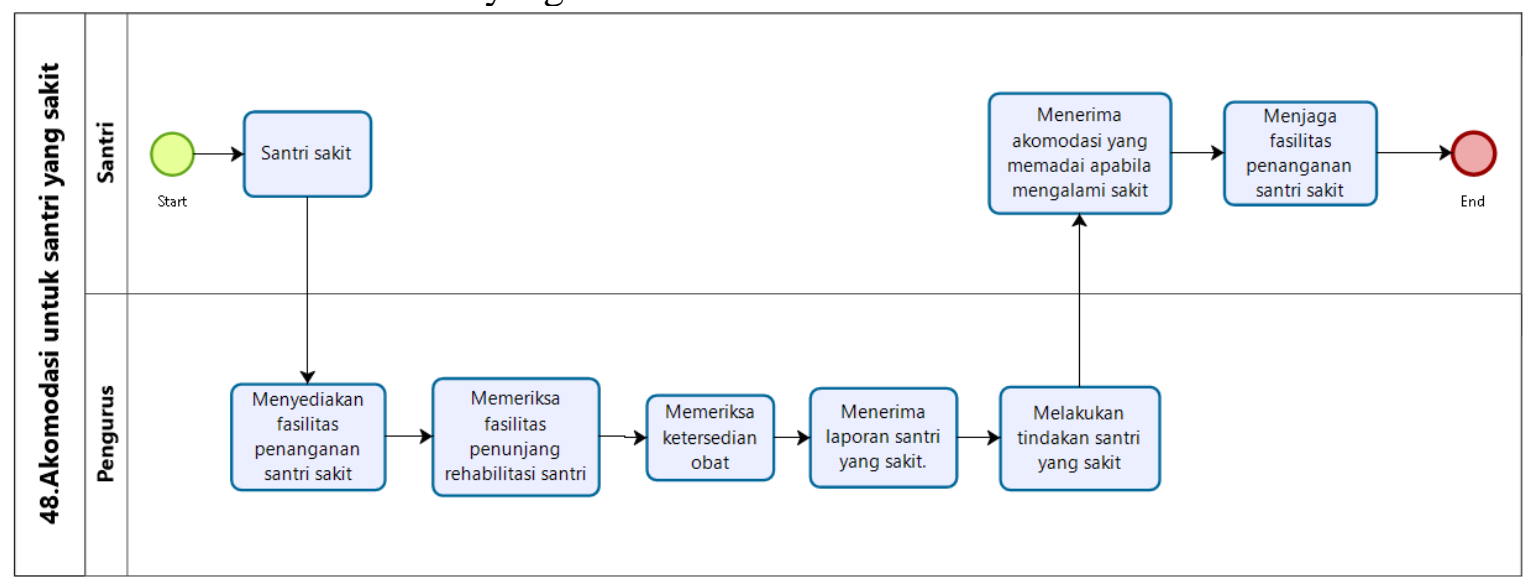

Gambar 49. Model Proses bisnis standar Akomodasi untuk murid yang sakit

Gambar 49 menggambarkan akomodasi santri sakit. Dimulai dari Pengurus menyediakan fasilitas penanganan santri sakit. pengurus secara berkala memeriksa fasilitas rehabilitasi santri sakit. ketika menerima laporan santri sakit fasilitas telah siap untuk digunakan. Santri sakit dan santri pendamping wajib menjaga fasilitas penanganan santri sakit.

49. Laundry

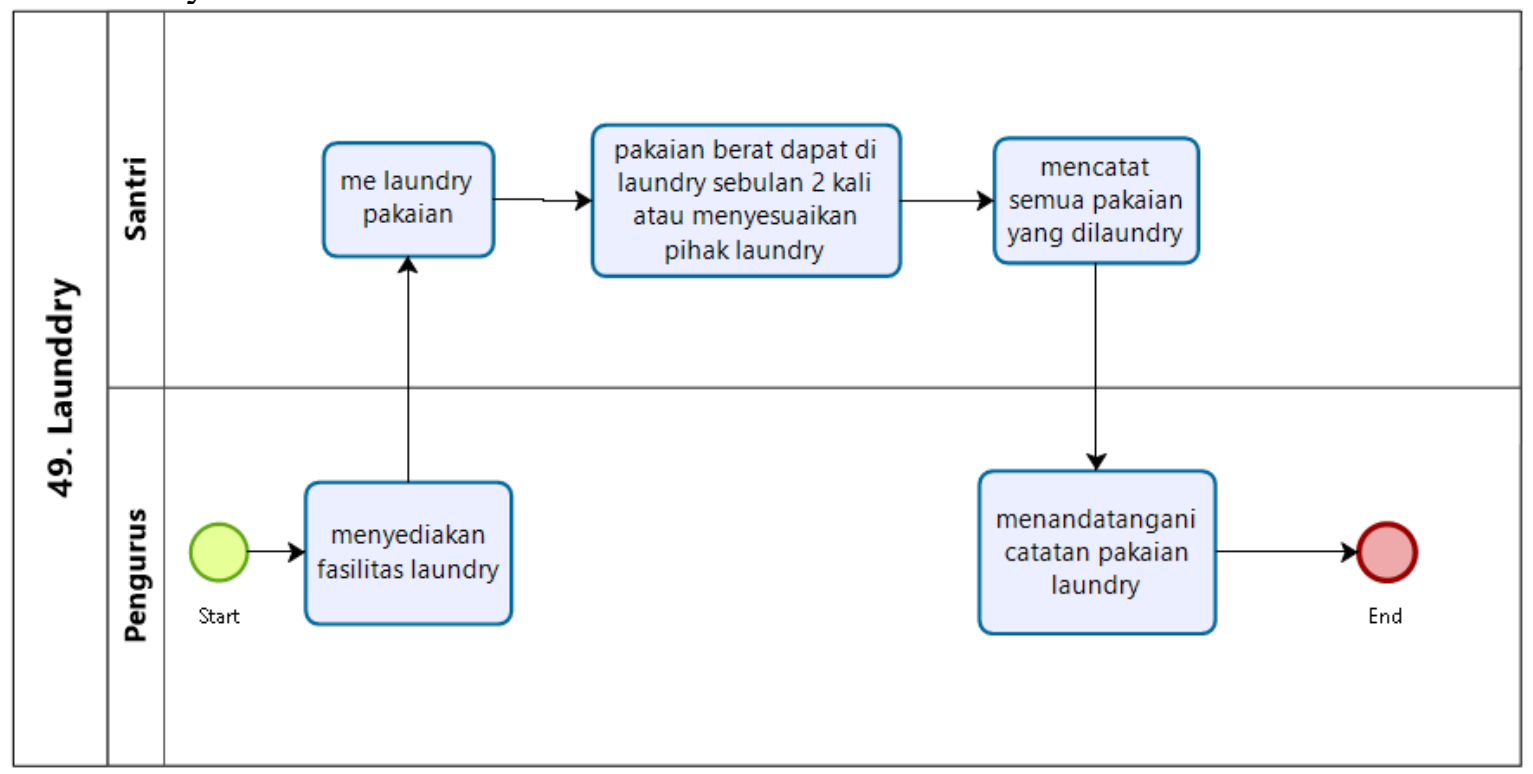

Gambar 50. Model Proses bisnis standar Laundry

Gambar 50 menggambarkan prosedur laundry. Dimulai dari Pengurus menyediakan fasilitas laundry. Santri yang menggunakan fasilitas laundry dapat melaundry pakaian berat sebulan 2 kali. Santri wajib mencatat semua pakaian laundry. Pengurus memvalidasi catatan laundry dengan menandatangani. 


\section{Alat tulis dan barang pribadi}

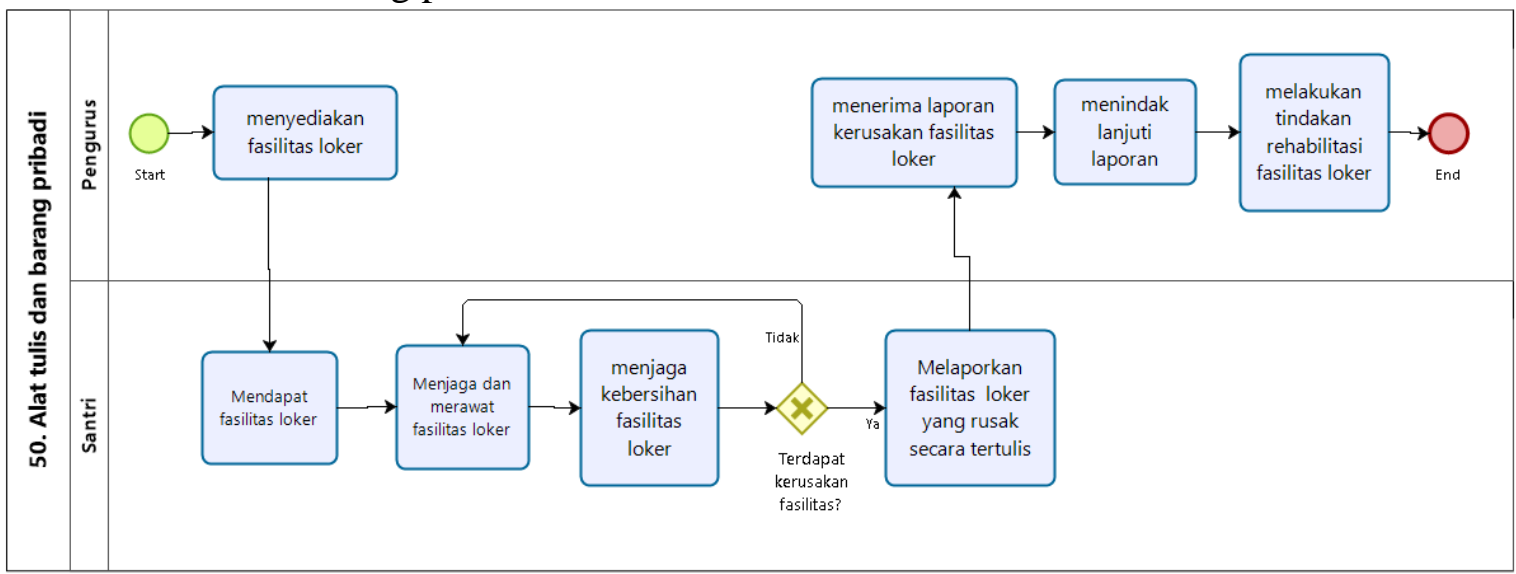

Gambar 51. Model Proses bisnis standar Alat tulis dan barang pribadi

Gambar 51 menggambarkan prosedur penyimpanan barang pribadi. Dimulai dari Pengurus menyediakan loker sebagai fasilitas penyimpanan barang pribadi Santri. Santri wajib menjaga dan merawat fasilitas loker. jika terdapat kerusakan fasilitas harus melapor secara tertulis ke pengurus yang nantinya akan menindak lanjuti laporan. Kemudian pengurus memvalidasi laporan. Pengurus segera melakukan tindakan rehabilitasi fasilitas.

51.Penginapan

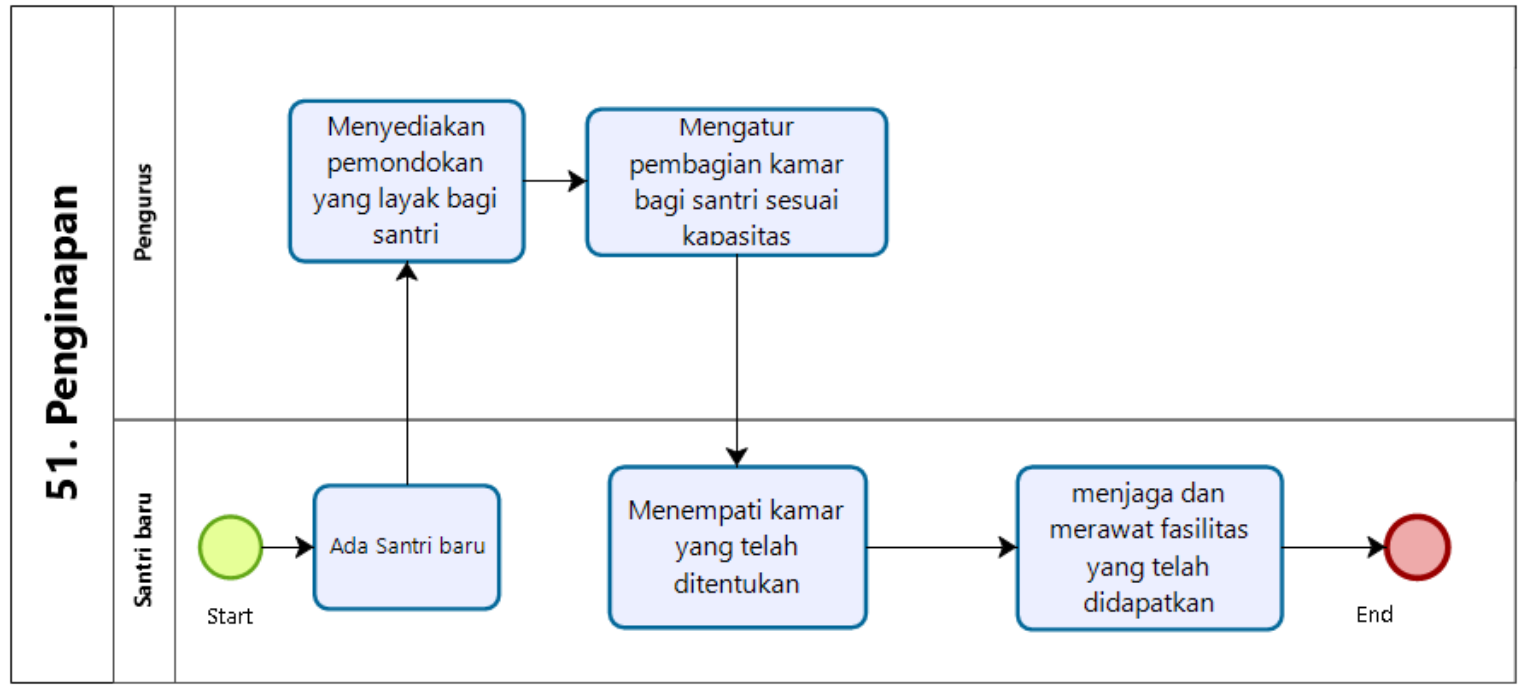

Gambar 52. Model Proses bisnis standar Kesejahteraan penghuni asrama yang ditempatkan di penginapan dijaga dan dipromosikan

Gambar 52 menggambarkan prosedur penginapan santri baru. Dimulai dari adanya santri baru. Pengurus menyediakan pemondokan yang layak bagi santri baru. Kemudian pengurus mengatur kapasitas dan membagi santri sesuai kapasitas kamar. Santri wajib menjaga dan merawat fasilitas pemondokan. 
52. Akomodasi dan pertukaran di luar lokasi

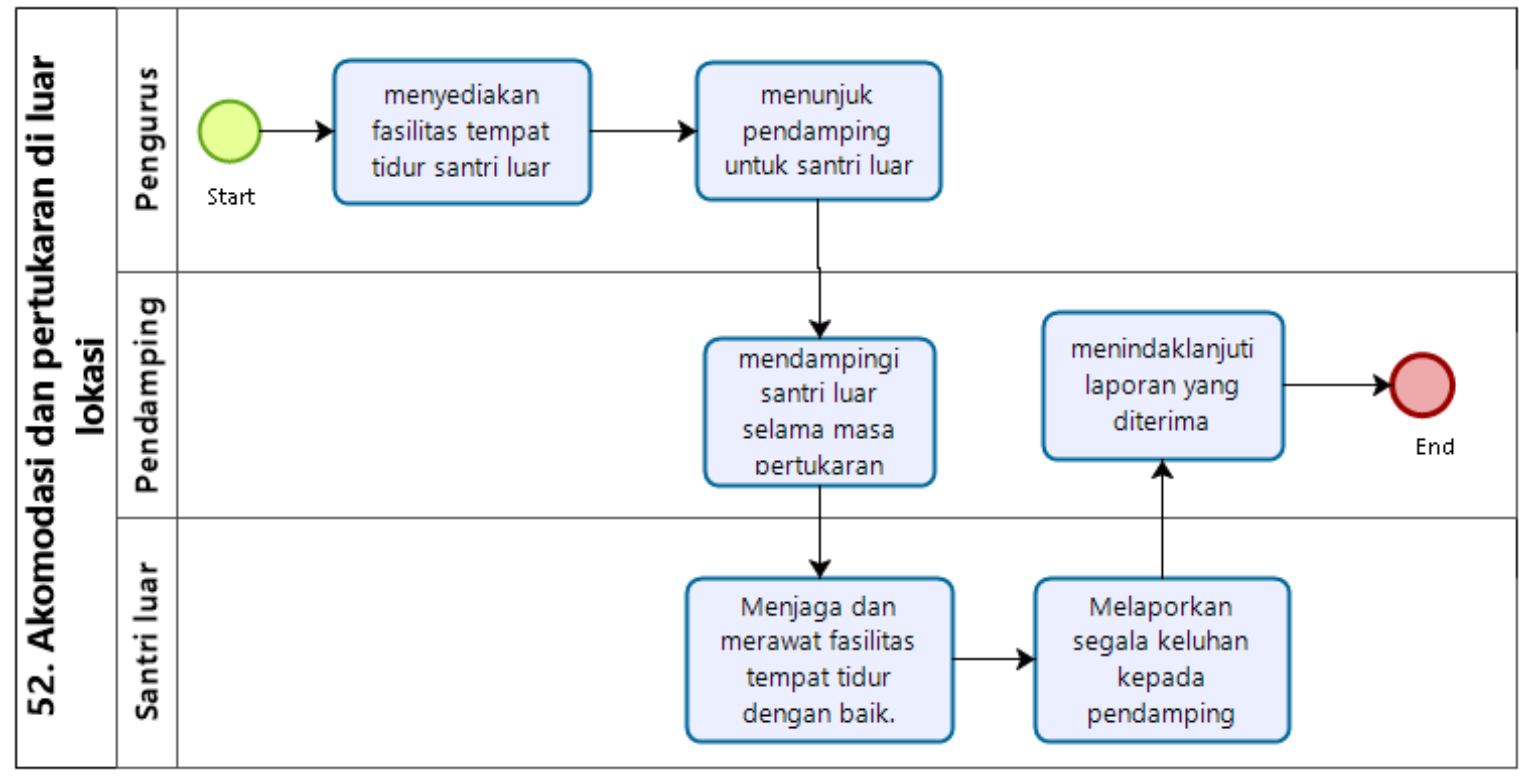

Gambar 53. Model Proses bisnis standar Akomodasi dan pertukaran di luar lokasi

Gambar 53 menggambarkan prosedur akomodasi pertukaran santri. Dimulai dari Pengurus menyediakan tempat tidur. Pengurus menunjuk pendamping santri luar untuk mendampingi selama masa pertukaran. Santri wajib menjaga dan merawat fasilitas tempat tidur. jika terdapat kerusakan fasilitas harus melapor secara tertulis ke pendamping yang nantinya akan menindak lanjuti laporan. Pengurus segera melakukan tindakan rehabilitasi fasilitas.

\section{KESIMPULAN}

Pembuatan proses bisnis Sekolah Standar Asrama dapat dilakukan dengan menerapkan Work Breakdown Structure mulai dari perincian Sekolah Standar Asrama kemudian menjabarkan aktivitas pada setiap standar. Dalam penelitian ini, peneliti mengusulkan masing-masing proses bisnis dari 52 standar Sekolah Standar Asrama yang nantinya dapat diterapkan di sekolah berasrama secara umum dan pondok pesantren secara khusus. Peneliti berharap pada penelitian yang akan datang, penelitian ini dapat disempurnakan maupun dapat menjadi rujukan untuk penelitian lain.

\section{REFERENSI}

[1] A. Shiddiq, "Tradisi Akademik Pesantren," Tadris J. Pendidik. Islam, Vol. 10, No. 2, 2015.

[2] N. Rizqi, U. Hidayati, T. A. Ramadhan, And M. A. Yaqin, "Simulasi Proses Bisnis Pondok Pesantren Menggunakan Anylogic Berdasarkan Metode Business Process Improvement (BPI)," Jurasik (Jurnal Ris. Sist. Inf. Dan Tek. Inform., Vol. 5, No. 1, P. 138, 2020, Doi: 10.30645/Jurasik.V5i1.178.

[3] A. Yunus, A. C. Fauzan, A. N. Faizin, And K. Sabbihatul, "Analisis Control Flow Complexity Untuk Komparasi Kompleksitas Proses Bisnis Penerimaan Mahasiswa Baru Universitas Nahdlatul Ulama Blitar Berbasis Petri Net Modelling Language,” Vol. 1, No. 2, Pp. 39-46, 2019.

[4] W. A. Government, "National Minimum Standards For Residential Special Schools Welsh Assembly Government," 2003.

[5] A. H. Anshori, "Pentingnya Manajemen Berbasis Sekolah/Madrasah....," Tarbawi, Vol. 2, Pp. 23-38, 2016.

[6] A. Maddeppungeng, I. Suryani, And M. Iskandar, “Analisis Pengendalian Penjadwalan Pembangunan Gedung Administrasi Universitas Pendidikan Indonesia (Upi) Kampus Serang Menggunakan Metode Work Breakdown Structure (Wbs) Dan Kurva-S,” J. FONDASI, Vol. 4, No. 1, Pp. 88-98, 2015.

[7] I. Ismanto, F. Hidayah, And K. Charisma, "Pemodelan Proses Bisnis Menggunakan Business Process 
Modelling Notation (BPMN) (Studi Kasus Unit Penelitian Dan Pengabdian Kepada Masyarakat (P2KM) Akademi Komunitas Negeri Putra Sang Fajar Blitar)," Briliant J. Ris. Dan Konseptual, Vol. 5, No. 1, P. 69, 2020, Doi: 10.28926/Briliant.V5i1.430.

[8] R. Khera, P. Ransom, And T. F. Speth, "Using Work Breakdown Structure Models To Develop Unit Treatment Costs," J. Am. Water Works Assoc., Vol. 105, No. 11, Pp. 61-62, 2013, Doi: 10.5942/Jawwa.2013.105.0129.

[9] R. C. Tausworthe, "The Work Breakdown Structure In Software Project Management," J. Syst. Softw., Vol. 1, No. C, Pp. 181-186, 1979, Doi: 10.1016/0164-1212(79)90018-9.

[10] S. A. Brotherton, R. T. Fried, And E. S. Norman, “Applying The Work Breakdown Structure To The Project Management Lifecycle," PMI Glob. Congr. Proc., Pp. 1-15, 2008.

[11] Ayu Herzanita, "Penggunaan Standard Wbs (Work Breakdown Structure) Pada Proyek Bangunan Gedung,” J. Infrastruktur, Vol. 5, No. 1, Pp. 29-34, 2019, Doi: 10.35814/Infrastruktur.V5i1.613.

[12] S. Kiswati And U. Chasanah, "Perencanaan Manajemen Proyek Dalam Meningkatkan Efektifitas Kinerja Sumber Daya Manusia Di Semarang Jawa Tengah," Neo Tek., Vol. 6, No. 1, 2020. 